\title{
TOWARD A Twenty-First CENTURy CiviL Commitment Statute: A Legal, Medical, ANd Policy Analysis of Preventive OUtPatient TREATMENT
}

\author{
Rachel A. Scherer ${ }^{*}$
}

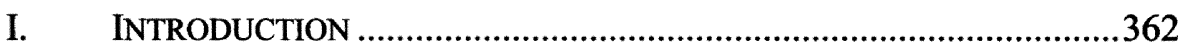

II. THE EVOLUTION OF PVOT: A CIVIL COMMITMENT STATUTE......363

III. RECENT SCIENTIFIC AND MEDICAL ADVANCEMENTS CONCERNING SEVERE AND PERSISTENT MENTAL ILLNESS .................................371

A. What Constitutes A Severe and Persistent Mental Illness? ...... 371

B. Genetics and the Environment ...........................................373

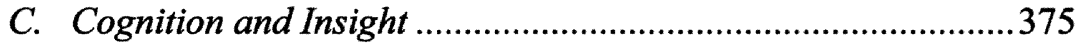

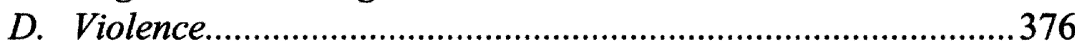

E. Medication and Other Forms of Treatment ............................379

IV. ROBERT'S STORY: A HUMAN FACE TO THE FAILURES OF THE DANGER-OR-GRAVE-DISABILITY STATUTES.................................382

A. Robert's Chances for Treatment Under A Typical Danger-orGrave-Disability Statute..................................................... 383

B. Robert's Chances for Treatment Under a PVOT Statute ..........384

V. THE LANGUAGE OF THE MODEL PVOT STATUTES: KENDRA'S LAW

AND LAURA'S LAW ..................................................................385

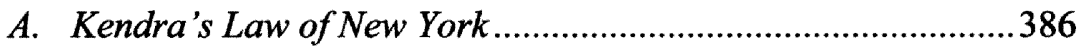

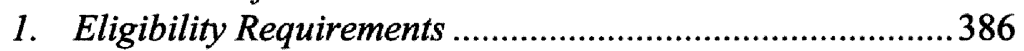

2. Third Parties That May Petition the Court to Determine

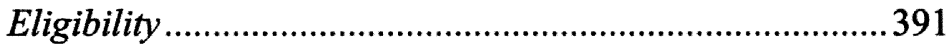

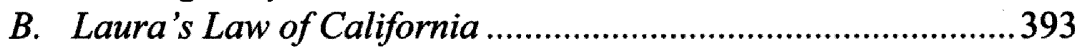

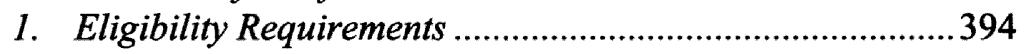

2. Third Parties That May Petition the Court to Determine Eligibility.

VI. JURISDICTIONS THAT HAVE MODELED LEGISLATION AFTER KENDRA AND LAURA..........................................................................396

A. Enacted PVOT Statutes ............................................................396

B. Other Jurisdictions Transitioning to Add PVOT....................398

VII. CONSTITUTIONAL ANALYSIS OF PVOT STATUTES .......................401

* J.D., 2007, Indiana University School of Law, Indianapolis, Indiana; B.A., 2003, University of Pennsylvania, Philadelphia, Pennsylvania. Questions and comments may be directed to the author at rscherer@alumni.upenn.edu. I would like to thank three people without whom this Note would not be where it is today: Clare Maier, for her countless and thoughtful edits of this Note; Rusty Selix, for his assistance in clarifying key aspects of California mental health law; and Professor R. George Wright, for his numerous edits, suggestions, and research ideas, and for challenging me to think critically, objectively, and abstractly on this particular topic. 
VIII. REPORTS AND DATA ON THE EFFECTS OF PVOT STATUTES 407

A. What Types of Severely Mentally Ill Persons-and How ManyAre Being Treated Under PVOT?

B. How Long Are PVOT Treatment Orders Lasting: Are Patients Complying with Their Medication and Treatment Plans Under PVOT?

C. What Are The Effects of PVOT on Incarceration Rates?

D. What Are the Effects of PVOT on Rates of Homelessness?..... 415

E. Other Benefits of PVOT

IX. THE TRUTH BEHIND LAURA'S LAW-THE CALIFORNIA GHOST LAW

A. Proposition 63: The Mental Health Services Act.

X. ALTERNATIVES TO PVOT

A. Mental Health Courts as Criminal Diversion Programs .........428

B. Rebuilding and Expanding Inpatient Hospitals

C. Improving Awareness and Education of Severe Mental Illness Through Early Prevention...

D. Comprehensive Voluntary Services Programs

XI. CONCLUSION

\section{INTRODUCTION}

Chronically and severely mentally ill persons present unique challenges for society. For centuries, legislatures have sought to address the conundrum of protecting the public from harm caused by severely mentally ill individuals, as well as the harm severely mentally ill individuals may cause to themselves, while commensurately protecting the civil liberties of such individuals. Finding a balance between these competing interests is not an easy task and remains unsettled. A new type of civil commitment statute called "preventive outpatient treatment" ("PVOT") 1 offers a promising solution.

The media coverage surrounding the adoption of PVOT statutes in New York and California in 1999 and 2002, respectively, ${ }^{2}$ has led to increased attention to PVOT statutes since the turn of the twenty-first century. ${ }^{3}$ Several states

1 See infra Part II notes 35-39 and accompanying text for a discussion as to why the author chose to call these statutes PVOT rather than AOT.

2 Kendra's Law, ch. 408, 1999 N.Y. Laws 2870 (codified at N.Y. MENTAL HYG. LAW $\S$ 9.60 (McKinney 2006)); Assisted Outpatient Treatment Demonstration Project Act of 2002 ("Laura's Law"), ch. 1017, 2002 Cal. Legis. Serv. 5046 (West) (codified at CAL. WELF. \& INST. CODE $\S \S 5345-5349.1$ (West Supp. 2007)).

3 See Michael L. Perlin, Therapeutic Jurisprudence and Outpatient Commitment Law: Kendra's Law as Case Study, 9 Psychol. Pub. POL'y \& LAw 183, 184 (2003). The Virginia Tech massacre also brought significant media attention toward PVOT. E. Fuller Torrey, Commitment Phobia, WALl St. J., Apr. 27, 2007, at A17 (citing Kendra's Law) [hereinafter Torrey, 
have since modeled their own PVOT statutes after those of New York and California. ${ }^{4}$ Florida and Michigan, for example, have done this as recently as 2005..$^{5}$ Additionally, PVOT statutes are gaining an international status and attention, with increasing endorsements from mental health associations and agencies, such as The Treatment Advocacy Center, ${ }^{6}$ The American Association of Psychiatrists, and The National Institute for Mental Health. ${ }^{7}$

This Note undertakes a critical review of PVOT statutes through the two most prominent current PVOT statutes, New York's Kendra's Law and California's Laura's Law. ${ }^{8}$ The focus will be on discussing these statutes' basic statutory language and purposes, the latest statistical reports regarding effectiveness, relevant case law regarding their usage, and the constitutional debates that surround them.

PVOT statutes offer a promising and much needed update to state civil commitment statutes. Nonetheless, PVOT may not be the only option, or even the best one, to improve the United States' mental health care system. More research needs to be conducted before we can reach any definitive conclusion concerning PVOT. Yet in some shape or form, PVOT statutes seem bound to leave a lasting imprint as we move toward increasingly health-care-conscious civil commitment statutes.

\section{The Evolution of PVOT: A CIVIL COMMITMENT STATUTE}

Mental illness has historically been misunderstood, misdiagnosed, and mistreated. ${ }^{9}$ Isolation, hydrotherapy, insulin coma therapy, convulsive thera-

Commitment Phobia].

It appears the earliest PVOT statute (similar in form to that which this Note addresses) was enacted by North Carolina in 1983. See N.C. GEN. STAT. §§ 122C-261(a)(ii), 122C263(d)(1) (2005); Jennifer Honig \& Susan Stefan, New Research Continues to Challenge the Need for Outpatient Commitment, 31 New ENG. J. ON CRIM. \& Civ. CoNFINEMENT 109, 110 (2005). Hawaii also enacted a PVOT statute before 1990, which is also similar to those PVOT statutes this Note addresses. See Haw. Rev. Stat. ANN. § 334-121 (LexisNexis 2004). E.g., John K. Cornwell \& Raymond Deeney, Preventive Outpatient Treatment For Persons With Serious Mental Illness: Exposing the Myths Surrounding Preventive Outpatient Commitment for Individuals with Chronic Mental Illness, 9 PSYCHOL. PUB. POL'Y \& L. 209, 213 \& n.28 (2003); Erin O'Connor, Note, Is Kendra's Law a Keeper? How Kendra's Law Erodes Fundamental Rights of the Mentally Ill, 11 J.L. \& PoL'Y 313, 322 \& n.34 (2002).

${ }^{4}$ See infra Part VI.A.

5 Id.

6 The Treatment Advocacy Center drafted the model PVOT legislation. TREATMENT Advoc. CTR., MODEL LAw For Assisted TREATMENT (2000), available at www.psychlaws.org/LegalResources/ModelLaw.htm [hereinafter TREATMENT ADVOC.CTR., MODEL LAW For AsSISTED TREATMENT].

7 E.g., Treatment Advoc. Ctr., http://www.psychlaws.org (last visited Mar. 9, 2006).

${ }^{8}$ Honig \& Stefan, supra note 3, at 110-11. See also Mark Fritz, A Doctor's Fight: More Forced Care For the Mentally Ill, WALL ST. J., Feb. 1, 2006, at A1.

9 See, e.g., Sarah Linsley Starks \& Joel T. Braslow, The Making of Contemporary American Psychiatry, Part 1: Patients, Treatments, and Therapeutic Rationales Before and 
pies, lobotomies, and sterilization were some of the radical and misguided treatments administered to treat mental illnesses in our not so distant past. ${ }^{10}$ Civil commitment statutes of the mid twentieth century, the "danger-to-oneself-oranother or gravely disabled" ("danger-or-grave-disability") statutes responded to the horrors of these treatments. ${ }^{11}$ Additionally, a national shift toward outpatient rather than inpatient treatment took place. ${ }^{12}$ Variations of the danger-or-

After World War II, 8 HISTORY OF PSYCHOL. 176, 177, 183-84 (2005) (describing lobotomies in particular). One of the first American psychiatric asylums took up the practice of charging admission fees to the increasing number of curious sightseers who wished to view, and often harass, the insane patients. E.g., Joanmarie Ilania Davoli, No Room at the Inn: How the Federal Medicaid Program Created Inequities in Psychiatric Hospital Access for the Indigent Mentally Ill, 29 AM. J. L. \& MED. 159, 167 (2003) ("At first, people came to view the mentally ill without official sanction. 'It was customary ... for idlers and thrill-seekers to gather about the cell windows of the insane ... and to take turns at "teasing the crazy people," with the aim of rousing them into raving fury.' As an attempt to dissuade the locals from coming to view the mentally ill, the hospital officials began to charge a fee for admission.") (quoting ALBERT DEUTSCH, THE MENTALLY ILL IN AMERICA 63-64 (1937)) (describing the Pennsylvania Hospital, which opened in 1756). Ironically, the word "asylum" originally was defined as a place of "shelter or protection from danger." THE CONCISE OXFORD ENGLISH DiCTIONARY ONLINE (Catherine Soanes \& Angus Stevenson, 11th ed. 2006).

10 Jennifer Gutterman, Note, Waging A War on Drugs: Administering A Lethal Dose To Kendra's Law, 68 FoRDHAM L. REv. 2401, 2405 (2000); Starks \& Braslow, supra note 9, at 183-84. At the time, however, lobotomies were seen as revolutionary tools to help control mental patients in hospital settings; in 1949 Egas Moniz, the first doctor to direct a modern lobotomy for psychiatric purposes, was awarded the Nobel Prize in Physiology and Medicine. Starks \& Braslow, supra note 9, at 184-85. But see KITTY DUKAKIS \& LARRY TYE, SHOCK: THE HEALING PowER OF ElECTROCONVULSIVE THERAPY passim (2006) (discussing the therapeutic value and importance of electroconvulsive therapy in modern psychiatry).

11 See, e.g., Laura E. Hortas, Note, Asylum Protection for the Mentally Disabled: How the Evolution of Rights for the Mentally Ill in the US Created a "Social Group," 20 CONN. J. INT'LL. 155, 164 (2004) (noting that during the 1960s and 1970s a higher standard for substantive commitment criteria was established).

Homosexuality provides a concrete illustration of some of the horrors that can arise in a legal system that is too deferential to medical doctrines. In early versions of the American Psychiatric Association's Diagnostic and Statistical Manual ("DSM"), homosexuality was defined and listed as a mental illness. See, e.g., WLLIAM N. EsKRIDGE, JR., DYNAMIC STATUTORY INTERPRETATION 53-54 \& 347 n.20 (1994). Homosexuality is no longer considered a mental illness among medical professionals and according to the DSM. Id. at 53-54. Such an example shows that permitting civil commitment based on a strict medical model could erode rights of individuals due to medical error or inaccurate scientific theories. $C f$. id. Ideally, a balance between accurate medical and legal advances may create the most efficient and effective civil commitment laws.

The danger-or-grave-disability statutes were not only responding to inaccurate medical doctrines but also to the horrors of judicial opinions that, for instance, sanctioned the sterilization of the mentally ill in the early twentieth century. Buck v. Bell, 274 U.S. 200, 207 (1927) (Holmes, J.) ("Three generations of imbeciles are enough. ... It is better for all the world, if instead of waiting to execute degenerate offspring for [a] crime, or to let them starve for their imbecility, society can prevent those who are manifestly unfit from continuing their kind.") (upholding sterilization of the mentally disabled in a psychiatric hospital).

${ }_{12}$ Several revolutionary changes in the medical, scientific, and political fields (directly 
grave-disability statutes are currently the law in all fifty states and serve to set a constitutional floor for state inpatient and outpatient civil commitment statutes. $^{13}$

related to mental health care) facilitated this major ideological shift. First, in the mid-1950s, the invention of antipsychotic drugs offered a far less invasive way to treat the severely and persistently mentally ill. Chlorpromazine (also known as Thorazine or Largactil) was the first antipsychotic drug, and it was put on the market in the mid-1950s. See, e.g., E. FULLER TORREY, SURVIVING SCHIZOPHRENIA: A MANUAL FOR FAMIIIES, CONSUMERS, AND PROVIDERS 197 (5th ed. 2006) (1983) [hereinafter TORREY, SURVIVING SChIzOPHRENIA]. See also Nancy K. Rhoden, The Limits of Liberty: Deinstitutionalization, Homelessness, and Libertarian Theory, 31 EMORY L.J. 375, 379 (1982) (citing ANDREW T. SCULL, DECARCERATION: COMMUNITY TREATMENT AND THE DEVIANT: A RADICAL VIEW 80 (1977)). Second, the Civil Rights Movement brought about a political era in which individual civil liberties of the severely mentally ill were heavily guarded by grassroots organizations and legislatures and carefully scrutinized by courts. Hortas, supra note 11 , at $156,162 \&$ n. 68 .

Third, the enactment of Medicare and Medicaid in 1965 statutorily excluded federal health insurance coverage for inpatient hospitalization, in part, due to the appeared magic bullet effect of antipsychotic drugs. See, e.g., Davoli, supra note 9, at 170 (" 'except for those over sixty-five, the federal government would only provide benefits to persons not in state hospitals. To shift the financial burden to the federal government, states had to send patients into the community [for mental health treatment]." ) (quoting RAEL JEAN ISAAC \& VIRGINIA C. ARMAT, MAdNeSS IN THE StREeTs 102 (1990)). Cf. John D. Morris, President Signs Medicare Bill; Praises Truman, N.Y. TIMES, July 31, 1965, at A1, C8 (publicizing the expansion of health insurance for Americans age sixty-five and older while simultaneously minimizing any discussion of insurance for disabled persons). By the end of the twentieth century, Medicaid's mental health inpatient exclusionary provision would prove to be a substantial roadblock to the effective treatment of the severely mentally ill in the states. "Medicaid's exclusion of the majority of adults in psychiatric hospitals from its reimbursement program created a major incentive for states to simply vastly reduce the number of institutionalized patients, and to close hospitals altogether [in turn, releasing such patients to the streets]." Davoli, supra note 9, at 169. What has been termed as the "deinstitutionalization" of the mentally ill, or in other words the sudden movement of the mentally ill from inpatient hospitals to alleged community treatment programs, may have been significantly caused by the Medicaid inpatient exclusion. See, e.g., id. at 169-70.

Deinstitutionalization may appear to have a positive connotation at first, but it has proven to have serious tangential and unintended effects on the administration mental health treatment in America, including criminalizing and marginalizing the mentally ill over the last several decades. Some scholars even refer to the deinstitutionalization movement as "transinstitutionalization" because it failed to de-institutionalize the mentally ill but instead transferred them to the prisons, yet another type of "institution." See Rhoden, supra note 12, at 391; Davoli, supra note 9, at 169-70. In hindsight, the Medicaid exclusion was probably most accurately a premature overreaction to the advent of antipsychotic drugs, and when coupled with the danger-or-grave-disability statutes, in many ways resulted in a social-reform-based suicide.

13 See Treatment Advoc. CTR., STAte STANDARds for Assisted Treatment: State BY STATE CHART passim (2007), available at $\mathrm{http} / /$ www.psychlaws.org/LegalResources/documents/StateStandards-TheChart_000.pdf (detailing the key language of each state's civil commitment statute; language concerning dangerousness or risk of harm or injury is present in each). United States Supreme Court decisions sanctioned the danger-or-grave-disability legislative reforms by switching from a medical model (focusing on the presence of a mental illness) to a legal one (focusing on criteria such as dangerousness). O'Connor v. Donaldson, 422 U.S. 563,575 (1975) ("A finding of mental illness alone cannot justify [commitment] ... [the individual must also be dangerous]."); see also Hortas, supra note 11, at 164. This change reflected 
The danger-or-grave-disability statutes typically require by the demanding standard of "clear and convincing evidence" nent ${ }^{15}$ or a substantial risk of ${ }^{16} 1$ ) danger to oneself or another or 2) grave disability. ${ }^{17}$ The danger-or-grave-disability statutes have proven to have serious

the Supreme Court's belief that a medical diagnosis of "mental illness" alone was not enough to deprive an individual of his or her legal right to liberty. O'Connor, 422 U.S. at 575.

14 Findings by "clear and convincing" evidence are the constitutional minimum for civil commitment statutes. Addington v. Texas, 441 U.S. 418, 433 (1979). Therefore, some states have enacted the higher standard of "beyond a reasonable doubt." See id. Clear and convincing evidence is more than a "preponderance of the evidence" typically required in civil cases but less than "beyond a reasonable doubt" required in criminal cases.

15 A few examples of state immanency standards that gauge dangerousness in civil commitment statutes are as follows: 1) "real and present threat of substantial harm," ALA. CODE $§$ 22-52-10.4(a) (LexisNexis 1975 \& Supp. 2006) (applied only to inpatient treatment); 2) "clear and present danger," ARK. CODE ANN. § 20-47-207(c) (2001 \& Supp. 2005); and 3) "demonstrated danger of inflicting substantial physical harm upon others," Lanterman-Petris-Short Act, CAL. WeLF. \& INST. CODE $§ 5300$ (a) (West 1998).

An analogy to imminence of harm standards in free speech statutes might be made here. Subversive advocacy speech, or speech potentially directed to incite illegal activity, for example, is often adjudicated on a demanding "clear and present danger" standard. Schenck v. United States, 249 U.S. 47, 50 (1919) (Holmes, J.); Brandenburg v. Ohio, 395 U.S. 444, 447 (1969) (per curiam) (substituting an "imminence" test for what was previously referred to as the "clear and present danger" test). Yet in some states, such as Arkansas, this same "clear and present danger" standard is being applied to assess whether severely mentally ill individuals are in need of life enabling medical treatment. ARK. CODE ANN. § 20-47-207 (2001 \& Supp. 2005).

One approach is that we should be very reluctant to restrict mere speech and therefore the demanding standard is much needed, but that in the cases of severely mentally ill persons who seem likely to be at a risk of danger to themselves or others, the same demanding standard protects a very doubtful patient autonomy at an unnecessary risk to safety. Cf. e.g., Abrams v. United States, 250 U.S. 616, 628, 630 (1919) (Holmes, J., dissenting) ("It is only the present danger of immediate evil or an intent to bring it about that warrants Congress in setting a limit to the expression of opinion where private rights are not concerned."). The higher evidentiary burden of proof in criminal free speech cases may account for this difference in values to some extent. In criminal free speech cases, the burden of proof is beyond a reasonable doubt, whereas in civil commitment cases the burden of proof is by clear and convincing evidence. Therefore the burden of proving "clear and present danger" is reduced in civil commitment cases. Nonetheless, one is still left to wonder why such similar legal standards are used in two highly different situations.

${ }^{16}$ IND. CoDE ANN. § 12-7-2-53 (LexisNexis 2006) ("Dangerousness" in the civil commitment statute is defined as "a condition in which an individual as a result of mental illness, presents a substantial risk that the individual will harm the individual or others."). See also MASS. GEN. LAWS ANN. ch. 123, $\S 1$ (West 2003) ("Likelihood of serious harm" is defined in three ways, one of which is "a substantial risk of physical harm to other persons as manifested by evidence of homicidal or other violent behavior or evidence that others are placed in reasonable fear of violent behavior and serious physical harm to them ....").

17 In California's Lanterman-Petris-Short Act, "gravely disabled" is defined as "a condition in which a person, as a result of a mental disorder, is unable to provide for his or her basic personal needs for food, clothing, or shelter." CAL. WELF. \& INST. CODE $§ 5004.5(\mathrm{~h})(1)(\mathrm{A})$ (West 1998). Although the various texts of the danger-or-grave-disability statutes linguistically vary from state to state (as do their judicial interpretations), the gravely disabled standard is generally extremely difficult to establish in the case of a severely mentally ill individual. 
problems in their execution. ${ }^{18}$ Critically, the extraordinarily high level of proof these laws require has proven problematic in protecting both the safety of the public $^{19}$ and the safety (and health) of mentally ill persons themselves.

For many severely mentally ill persons, this standard is nearly impossible to prove in a court of law and resultantly fails to protect a significant population of severely mentally ill persons: those who are in need of treatment but are neither dangerous nor disabled to the extreme degree. The Virginia Tech massacre highlights this failure. In this mental health tragedy, a young college student presented a host of symptoms of a developing severe mental illness, which was reported by roommates and professors to authorities, but the mentally ill individual failed to receive any type of meaningful or lasting outpatient psychiatric treatment due to the high evidentiary requirement that he be an "imminent" danger to himself or others. ${ }^{20}$

Further, the danger-or-grave-disability statutes do not seek to prevent the deterioration of a severe mental illness. Rather, they wait for moments of extreme deterioration to occur before permitting involuntary treatment, by which time it may be too late to effectively rehabilitate the individual. From a medical and social welfare standpoint, it might be said that the danger-or-gravedisability statutes discriminate against the class of severely mentally ill persons whose mental illnesses are severe but manifest in less classically violent or debilitating ways.

PVOT statutes may be to the twenty-first century what the danger-orgrave-disability statutes were to the twentieth century. Just as the danger-orgrave-disability statutes responded to a cry against horrors of mental health care

For instance, in Indiana, which defines gravely disabled in much the same way as California, see IND. CODE ANN. § 12-7-2-96, "grave disability" was not established in a case in which a twenty-four-year-old diagnosed with schizophrenia was suffering from auditory hallucinations and perceived his roommates speaking to him through his computer speakers. In re Steinberg, 2004 Ind. App. LEXIS 2673, at *9 (2004). The court found that the individual was capable of maintaining an apartment with a roommate in a college town and there was no evidence that he was unable to provide for his "essential human needs" pursuant to the language of the statute. $I d$. at *10 (citing IND. CODE ANN. $§ 12-7-2-96$ ). Additionally, this twenty-four year old also failed to meet the substantial risk of imminent harm standard under the danger prong of the danger-or-grave-disability statute, even though he had been arrested several times and had pointed a gun at individuals in a college setting. Id. at *8. Therefore no involuntary treatment was ordered even though there were clear signs he was developing schizophrenia and also came from a family that had a history of the disease. $I d$. at *7, ${ }^{*} 10-11$.

18 For a compelling argument that all persons who are dangerous should be civilly committed, rather than only dangerous mentally ill persons, see ELYN R. SAKS, REFUSING CARE: FoRCED TREATMENT AND THE RightS OF THE MENTALLY ILL 50-51 (2002) [hereinafter SAKS, REFUSING CARE].

19 New York's PVOT statute, Kendra's Law, for example, was enacted after a middleaged male diagnosed with paranoid schizophrenia who had sought treatment previously but failed to meet the danger requirements, pushed an innocent bystander into a moving subway, causing her death. See Kendra's Law, N.Y. MENTAL HYG. LAw $\S 9.60$ (McKinney 2006); Fritz, supra note 8, at A12. See also infra Part V.A.

20 See, e.g., Torrey, Commitment Phobia, supra note 3. 
treatment that needed increased legal protection, PVOT statutes are responding to a cry against horrors of weak mental health care laws that need increased medical protection. PVOT statutes aim toward a more medically-based evidentiary approach compared to the danger-or-grave-disability statutes. This includes medical criteria such as severity and history of the mental illness in conjunction with stricter legal criteria, such as the traditional "dangerousness" standard. At the same time there remains a lurking caution and focus on individual liberties through hefty factor-based-safeguards to ensure that the core liberties and dignities of the severely mentally ill are still respected.

Additionally, PVOT statutes are a branch of outpatient commitment statutes ("OT") because of their focus on treatment in the community rather than in a psychiatric hospital twenty-four hours a day. ${ }^{21}$ OT statutes have been working in tandem with the danger-or-grave-disability statutes for several decades. Recent scholars, however, have been referring to OT more specifically as "assisted outpatient treatment" ("AOT") statutes. ${ }^{22}$ The purpose of the addition of the word "assisted" tends to emphasize that such individuals need more genuine assistance from the community in order to effectively adhere to their OT plans. $^{23}$

The traditional fears of institutionalization are somewhat of a fiction with respect to OT, AOT, and PVOT statutes. This is because the "commitment" is more figurative because the state seeks to ensure that the patient remains "committed" to the treatment plan likely to be the most beneficial rather than "committed" to a hospital. ${ }^{24}$ Though the term "civil commitment" sounds

21 Forty-two of the danger-or-grave-disability statutes have an AOT component. Treatment Advoc. CTR., Assisted OutPatient Treatment 1 (2005), available at http://www.psychlaws.org/BriefingPapers/BP4.pdf.

22 Treatment Advoc. CTR., MODEL LAw For Assisted TrEATMENT, supra note 6 § 2.1 .2 (defining "assisted treatment" and "assisted outpatient treatment").

23 Telephone Interview with Ron Honberg, Director of Policy \& Legal Affairs, National Alliance on Mental Illness, in Indianapolis, Ind., Apr. 2007 (stating that the Treatment Advocacy Center coined the term).

24 An involuntary AOT plan does not require that the individual be an inpatient of a twenty-four hour psychiatric hospital or a resident of a halfway house. Ken Kress, An Argument for Assisted Outpatient Treatment for Persons with Serious Mental Illness Illustrated with Reference to a Proposed Statute for Iowa, 85 IowA L. REV. 1269, 1291 (2000). Instead, an AOT plan is court-mandated psychiatric treatment that often includes taking medication "as a condition of remaining in the community." TREATMENT ADVOC. CTR., ASSISTED OUTPATIENT TREATMENT, supra note 21 , at 1 .

A typical ... [AOT] plan involves visiting a psychiatrist or mental health professional at regular intervals (generally every four to eight weeks), taking prescribed medications, and occasionally undergoing psychotherapy.... [Sometimes], it involves case management, rehabilitation, assistance in obtaining housing, and, if appropriate, assistance in obtaining employment.

Kress, supra note 24 , at 1291 . Violation of court-ordered AOT conditions typically results in the individual being hospitalized for further psychiatric treatment. TREATMENT ADVOC. CTR., ASSISTED OUTPATIENT TREATMENT, supra note 21, at 1 . In sum, AOT statutes require the patient 
somewhat archaic and invasive, and forced medication is still invasive in many respects, outpatient commitment is an improvement for mental health care because more liberty is likely to be preserved outside of the hospital setting. ${ }^{25}$ Overall, AOT statutes represent a movement toward outpatient treatment and away from inpatient treatment, with an increasing reliance on medication.

There are currently three types of AOT statutes, one of which includes PVOT. $^{26}$ First is the preventive or early intervention AOT. ${ }^{27}$ This type of AOT includes PVOT, as well as the danger-or-grave disability statutes (though to a more distant degree of prevention), and other types of preventive treatment such as criminal diversion programs, which are often administered through local mental health courts. ${ }^{28}$ Second is psychiatric-hospital diversion AOT. ${ }^{29}$ This type of statute permits individuals who are already civilly committed to avoid inpatient hospitalization and instead obtain treatment in the community. ${ }^{30}$ Third is conditional discharge AOT. ${ }^{31}$ This type of statute permits forced outpatient treatment for individuals who are discharged from a psychiatric hospital with a continued treatment plan that they must continue to follow. ${ }^{32}$

This Note focuses on the first type of AOT statute described above: prevention and early intervention. Only a limited number of states have enacted the type of PVOT statute that this Note addresses. ${ }^{33}$ While forty-two states have enacted general AOT statutes, these statutes include all three types of AOT and can be very different in nature. ${ }^{34}$

An important side note to this discussion is that due to the variation of the three major categories of AOT statutes, and because mental health legislation varies from state-to-state (and even county-to-county), different terms and abbreviations are being used interchangeably and possibly incorrectly in academic and medical discourse on the topic. For clarification purposes, and to ensure future discussions on the topic are accurate, the existing set of terms should be

to follow a prescribed treatment plan while permitting the individual to continue to live at a residence of his or her choice. See, e.g., Kress, supra note 24, at 1291.

${ }^{25}$ Contra SAKS, REFUSING CARE, supra note 18, at 87 ("[W] volves greater restrictions on one's [physical] liberty than does medication, the latter in a sense involves greater intrusion into one's person. It changes one's mental state - one's very thought processes-and in a way that can't be resisted by any effort.").

${ }^{26}$ E.g., Honig \& Stefan, supra note 3, at 110. See also Kress, supra note 24, at 1291.

27 Honig \& Stefan, supra note 3, at 110; Kress, supra note 24, at 1291.

28 See Honig \& Stefan, supra note 3, at 110; Kress, supra note 24, at 1291. See infra Part X.A (discussing mental health courts).

29 Honig \& Stefan, supra note 3, at 110; see Kress, supra note 24, at 1291.

${ }^{30}$ Honig \& Stefan, supra note 3, at 110; see Kress, supra note 24, at 1291.

31 Honig \& Stefan, supra note 3, at 110; Kress, supra note 24, at 1291.

32 Honig \& Stefan, supra note 3, at 110; Kress, supra note 24, at 1291.

33 See infra Part VI (describing the PVOT statutes of Florida and Michigan, as well as at least three other states considering adopting PVOT). See supra note 3 (describing the PVOT statutes of North Carolina and Hawaii).

${ }^{34}$ See, e.g., Honig \& Stefan, supra note 3, at 110 \& n.5 (citing a Treatment Advoc. Ctr. paper); Kress, supra note 24, at 1291. See also TREATMENT ADVOC. CTR., AssisTED OUTPATIENT TREATMENT, supra note 21, at 1. 
consolidated or a new set should be devised in order to begin effectively distinguishing among the three types of AOT. Currently, medical and legal articles use terms such as "AOT,"35 "OT" (outpatient treatment), "PCT" (preventive commitment statutes), "POC" (preventive outpatient commitment), "COT" (community outpatient treatment), "IOC"38 (involuntary outpatient commitment), "OPC" ${ }^{39}$ (outpatient commitment), and "PACT" (preventive assisted community treatment), often, to refer to the same types of treatment. The problem - that these terms may have radically different meanings depending on the jurisdiction and context from which they arise-is somewhat of a microcosm for the broader problem that mental health care is often a local creature with few national (or sometimes even state-wide) enforcement mechanisms. Nonetheless, this Note uses the abbreviation PVOT to refer to the most recent subset of AOT statutes: those that do not require "dangerousness" (though may use it as an aspect) and permit evidence concerning the broader history of the mental illness to be taken into consideration for civil commitment.

PVOT statutes may be distinguished from traditional AOT or OT statutes even though each focuses on administering outpatient treatment under a civil commitment statute. ${ }^{40}$ The goal of PVOT is to use the latest advances in psychopharmacological drugs in conjunction with a variety of therapies and vocational counseling to foster the rehabilitation of the severely mentally ill through regular, monitored, and lengthier outpatient psychiatric treatment. ${ }^{41}$ Treatment plans under PVOT last for at least six months and involve a broader system of support between the PVOT recipient and a wide array of counselors including therapists, social workers, vocational workers, and psychiatrists. ${ }^{42}$ Treatment plans are also individually tailored to each individual, which makes it more likely that a patient will adhere to his or her outpatient treatment plan. ${ }^{43}$

35 Honig \& Stefan, supra note 3, at 110.

${ }^{36}$ Cf. Kress, supra note 24, at 1291 (proposing an assisted outpatient treatment statute with some aspects of conditional release yet referring to it as "outpatient treatment") ("Henceforward, when I deploy the phrase 'outpatient treatment' in this Article to refer to the proposed statute, I refer to preventive treatment, unless the context otherwise makes clear.").

37 Cornwell \& Deeney, supra note 3, at 209 \& n.3 ("For the purpose of uniformity, we will use the term Preventive Outpatient Commitment or POC throughout the article, recognizing that some jurisdictions prefer different terminology. For example, in New York, POC is referred to as Assisted Outpatient Treatment or AOT.").

${ }^{38}$ Honig \& Stefan, supra note 3, at 110 ("OPC, also called preventive commitment, Assisted Outpatient Treatment ('AOT'), or Involuntary Outpatient Commitment ('IOC') ....").

39 Honig \& Stefan, supra note 3, at 109-10.

40 PVOT statutes, synonymous with "model law" used by the Treatment Advocacy Center, were in a sense created by the Treatment Advocacy Center through the "compilation of the most effective provisions of existing state laws." Jonathan Stanley, Important Aspects of the Model Law, in TREATMENT AdVOC. CTR., MODEL LAW For AsSisted TREATMENT, supra note 6.

${ }^{41}$ See E. Fuller Torrey \& Mary T. Zdanowicz, Introduction to TREATMENT ADVOC. CTR., MODEL LAW For ASSISTED TREATMENT, supra note 6.

${ }^{42}$ See infra Part V.

43 Id. 
Recent reports show that PVOT statutes are having quantifiable positive effects in those states that have implemented them. ${ }^{44}$ Rates of homelessness, recidivism, incidences of harmful behaviors, and victimization of the severely mental ill are reported to have dropped significantly in the key PVOT state, New York. ${ }^{45}$ Additionally, PVOT statutes have reportedly improved both access to and effectiveness of mental health care for the severely mentally ill. ${ }^{46}$ This data suggest that states should build upon or implement PVOT to improve state mental health care systems.

\section{RECENT SCIENTIFIC AND MEDICAL ADVANCEMENTS CONCERNING SEVERE AND PERSISTENT MENTAL ILLNESS}

In order to consider any type of legal change that affects the severely mentally ill, it is important to identify the current medical and scientific understanding of the nature and development of severe mental illnesses.

\section{A. What Constitutes A Severe and Persistent Mental Illness?}

The DSM-IV ${ }^{47}$ does not define "severe and persistent mental illness.",48 Yet many mental health organizations, such as the Treatment Advocacy Center and the National Alliance on Mental Illness ("NAMI"), use the phrase to identify a certain group of mentally ill persons. ${ }^{49}$ Typically, "severely and persistently mentally ill" individuals are those who suffer from a DSM-IV Axis I

44 See infra Part VIII (discussing statistical results of the 2005 New York Final Report on Kendra's Law).

45 Id.

46 Id.

47 The Fourth edition of the Diagnostic and Statistical Manual of Mental Disorders is currently used by psychiatrists, physicians, and psychologists to diagnose mental illnesses. See AM. PSYCHIATRIC ASS'N, QUICK REFERENCE TO THE DIAGNOSTIC CRITERIA FROM DSM-IV-TR® xi (9th ed. 2005) [hereinafter AM. PsYCHIATRIC Ass'N, DSM-IV-TR].

48 Therefore medical professionals have been using it to make distinctions about a specific group of mentally ill individuals, those who are most in need of help.

The broad area of severe [and persistent] mental illness has suffered, in our view, from the lack of a clear working definition and it is time that one was agreed among those working in the field. This is necessary at a national level for assessing overall needs and resources and at local level for responding sensitively but explicitly to those persons most in need of help.

Andrew Barker \& Alain Gregoire, Defining Severe Mental Illness, in AdULT SEVERE MENTAL ILLNESS 1 (Alain Gregoire ed., 2000) (quoting Mental Health Found. 1994)(discussing some of the definitions proposed since the 1980s) (emphasis added).

49 E.g., Joe Vanable, President, NAMI Indiana, Panel Address at Norman Amaker Public Interest Law and Social Justice Retreat: Seeking Justice for People with Mental Illness (Feb. 24, 2007) (power point presentation on file with author). See generally Treatment Advoc. Ctr., http://www.psychlaws.org (last visited Mar. 9, 2006). 
disorder. ${ }^{50}$ This includes schizophrenia, schizoaffective disorder, bipolar disorder, and major depression. ${ }^{51}$

Symptoms of Axis I disorders may have three separate dimensions: 1) positive symptoms, 2) negative symptoms, and 3 ) cognitive symptoms. ${ }^{52}$ Positive symptoms include symptoms that did not exist before the development of the mental illness and are therefore new and more concrete. ${ }^{53}$ They include symptoms of hallucinations, paranoia, and delusions and are often associated with reality distortion. ${ }^{54}$ Negative symptoms include emotions that the individual may have experienced before the mental illness, such as sadness or anger, but now exhibits on a more regular basis. ${ }^{55}$ These symptoms are typically associated with a decline in emotional functioning, including social withdrawal or the inability to experience pleasure. ${ }^{56}$ Finally, cognitive symptoms include those symptoms that affect memory and attention. ${ }^{57}$

Because numerous Axis I disorders may include symptoms that are positive, negative, and cognitive, those suffering from schizophrenia, contrary to popular belief, are not the only class of severely mentally ill persons who might suffer from reality-distorting hallucinations and delusions. Those who suffer from bipolar disorder or major depression may also experience equally debilitating hallucinations or delusions. ${ }^{58}$ Hence, it is no longer accurate to think of

50 Axis I disorders do not include personality disorders, mental retardation, or psychosocial and environmental problems. AM. PSYCHIATRIC ASs'N, DSM-IV-TR, supra note 47, at 37. Physicians making a clinical diagnosis of an Axis I disorder also indicate the severity of the illness by specifying it as one of the following: "Mild, Moderate, Severe, In Partial Remission, In Full Remission, and Prior History." See id. at 2. "Severe" is defined as "[m]any symptoms in excess of those required to make the diagnosis, or several symptoms that are particularly severe, are present, or the symptoms result in marked impairment in social or occupational functioning." Id. at 3.

51 See id. at 37-38.

52 L.M. Camargo et al., Disrupted in Schizophrenia 1 Interactome: Evidence for the Close Connectivity of Risk Genes and a Potential Synaptic Basis for Schizophrenia, 12 MOLECULAR PSYCHIATRY 74, 74 (2007) (focusing on schizophrenia); Nami Family-to-Family Education Program, Symptoms Leading To a Diagnosis of Depression and Mania, at 2.25 (on file with author).

53 See Nami Family-to-Family Education Program, Symptoms Leading to a Diagnosis of Schizophrenia, at 2.20 (on file with author).

54 E.g., Camargo et al., supra note 52, at 74; Colm M.P. O'Tuathaigh et al., Susceptibility Genes for Schizophrenia: Characterisation of Mutant Mouse Models at the Level of Pheotypic Behavior, 31 NeUROSCIENCE \& BIOBEHAVIORAL REVS. 60, 61 (2007).

55 See Nami Family-to-Family Education Program, Symptoms Leading to a Diagnosis of Schizophrenia, at 2.20 (on file with author).

56 E.g., Camargo et al., supra note 52, at 74; see O'Tuathaigh et al., supra note 54, at 61.

57 See, e.g., Camargo et al., supra note 52, at 74; O'Tuathaigh et al., supra note 54, at 61; see also Christopher M. Wilk et al., No, It is Not Possible to Be Schizophrenic Yet Neuropscyhologically Normal, 19 NEUROPSYCHOLOGY 778, 778 (2005) (confirming that a core feature of schizophrenia is neuropsychological impairment).

58 Ted Coburn, In Our Own Voice, NAMI-Indiana, Opening Speaker at the 4th Annual Mental Health \& Criminal Justice Summit, Indianapolis (Mar. 23, 2007) (describing his per- 
major depression or bipolar disorder as immune from symptoms traditionally associated with the more classic severe mental illness, schizophrenia. ${ }^{59}$

\section{B. Genetics and the Environment}

Research has shown that both genetics and the environment play an important role in the development of severe mental illnesses. Genetic studies of schizophrenia suggest that the disease is caused by abnormal brain synapses. ${ }^{60}$ While no single gene has as yet been pin-pointed as the primary cause, several medical studies offer strong evidence that one or two particular genes may be closely connected with the malfunctioned synapse. ${ }^{61}$ Similarly, some medical researchers suspect that the cause of schizophrenia may be the result of a complex interaction of multiple genes, rather than any single gene. ${ }^{62}$ The multiple gene theory often incorporates the influence of environmental factors.

Studying the environment alongside genetics has been important to researchers because of the weaknesses in strict genetic theories. ${ }^{63}$ For instance, among identical twins there is estimated to be only a fifty percent chance of developing schizophrenia. ${ }^{64}$ Additionally, among fraternal twins and siblings, both of whom on average share the same percentage of parental genes, the risk of developing schizophrenia is only between nine and twenty-seven percent. ${ }^{65}$ Finally, from first-degree to second-degree relatives there is a considerable falloff in the risk of developing schizophrenia. ${ }^{66}$ These studies suggest that while a

sonal experiences with delusions and bipolar disorder). See also Richard Rende et al., Psychotic Symptoms in Pediatric Bipolar Disorder and Family History of Psychiatric Illness, $96 \mathrm{~J}$. AFFECTIVE DISORDERS 127, 127 (focusing a medical study on the relation between psychotic symptoms of pediatric bipolar patients and family history of severe mental illnesses, such as schizophrenia).

59 AM. PSYCHIATRIC Ass'N, DSM-IV-TR, supra note 47, at 198-99 (describing criteria for a severe major depressive episode with psychotic features or a severe manic episode with psychotic features).

${ }^{60}$ Camargo et al., supra note 52, at 74. Brain images of those diagnosed with schizophrenia suggest that the "reduced synaptic connectivity may result from improper neurodevelopment culminating from an underlying genetic predisposition ...." Id.

${ }^{61}$ See Camargo et al., supra note 52, at 75.

62 E.g., Lynn E. DeLisi \& Wolfgang Fleischhaker, Schizophrenia Research in the Era of the Genome, 2007, 20 CURRENT OPINION IN PSYCHIATRY 109, 110 (2007).

${ }^{63}$ One study, which focused on whole-genome association technology to study schizophrenia, supports "the presence of cytokine receptor abnormalities in schizophrenia . . . [, which] may help explain prior epidemiologic data relating to the risk for this illness to altered rates of autoimmune disorders, prenatal infection and family leukemia." T. Lencz et al., Converging Evidence for a Pseudoautosomal Cytokine Receptor Gene Locus in Schizophrenia, 12 MOLECULAR PSYCHIATRY 572, 572 (2007).

${ }^{64}$ E.g., Lencz et al., supra note 63, at 578. See also Robin McCreadie, Schizophrenia, in ADULT SEVERE MENTAL ILLNESS 12 (Alain Gregoire ed., 2000) (estimating that the concordance rate for schizophrenia in monozygotic twins is between thirty-five and fifty-eight percent); DeLisi \& Fleischhaker, supra note 62, at 110; see, e.g., O'Tuathaigh et al., supra note 54, at 61.

${ }_{65}$ McCreadie, supra note 64, at 12; DeLisi \& Fleischhaker, supra note 62, at 110.

${ }^{66}$ DeLisi \& Fleischhaker, supra note 62, at 110. 
genetic predisposition is certainly present for a disease like schizophrenia, it is arguably not the only —or even the controlling - factor. ${ }^{67}$

For some individuals, traumatic events may trigger the genetic predisposition to develop the illness. ${ }^{68}$ Other medical research studies have suggested a link between cannabis use and the development of severe mental disorders with psychotic symptoms. ${ }^{69}$ And still others show that "[w]ell-replicated findings of increased ... risk [of schizophrenia] for winter-born and urban-born individuals, combined with large-scale studies demonstrating increased risk following maternal exposure to a variety of infectious pathogens, have suggested that prenatal infection may represent a significant environmental risk factor." ${ }^{, 70}$ Additionally, a theory concerning a human virus transmitted by a parasite typically carried by cats has been proposed as an environmental factor that may influence a genetic susceptibility to schizophrenia. ${ }^{71}$

Research still needs to be conducted concerning the genetic and environmental interplay at work in the development and nature of severe mental illness. In the near future, with rapid scientific and technological advances, more con-

${ }^{67}$ Some genetic studies also show that a particular gene may influence the susceptibility of developing multiple Axis I disorders, such as bipolar disorder and schizophrenia. E.g., G. Vazza et al., Genome-Wide Scan Supports the Existence of A Susceptibility Locus for Schizophrenia and Bipolar Disorder on Chromosome 15q26, 12 MOLECULAR PSYCHIATRY 87, 87 (2007); P.A. Thomson et al., Association of Neuregulin 1 with Schizophrenia and Bipolar Disorder in a Second Cohort from the Scottish Population, 12 MOLECULAR PSYCHIATRY 94, 94, 100, 103 (2007); contra Rende et al., supra note 58, at 130 (noting a lack of association between psychosis in bipolar disorder and a family history of schizophrenia but also emphasizing the limitations of the study as the possible cause for the conclusion). Under this genetic-based theory, researchers are less focused on the classification of the mental illness but more on the extent to which any severe mental illness continues to manifest itself in the gene-sharing family. Some studies narrowing in on affective disorders, such as bipolar disorder and depression, have identified particular groups of chromosomes as potential genetic causes. David S. Baldwin, Affective Disorders, in ADULT SEVERE MENTAL ILLNESS 42 (Alain Gregoire ed., 2000). Interestingly, the genetic strength for developing bipolar disorder is stronger compared to both schizophrenia and depression. See id. at $\mathbf{4 3}$ (stating that the concordance rate for bipolar among identical twins is roughly seventy percent).

68 For example, one individual reported that his bipolar disorder, accompanied by delusions of being "the One" in the Matrix, when coupled with the tragic events and devastation he experienced on $9 / 11$, led him to violent reaction when he believed terrorists were on board an aircraft with him on a commercial plane. Ted Coburn, In Our Own Voice, NAMI-Indiana, Opening Speaker at the 4th Annual Mental Health \& Criminal Justice Summit (Mar. 23, 2007).

69 E.g., Don Linszen \& Therese van Amelsvoort, Cannabis and Psychosis: An Update on Course and Biological Plausible Mechanisms, 20 CURRENT OPINION IN PSYCHIATRY 116, 118 (2007) ("There seems to be no doubt that cannabis can induce psychosis in a subgroup of people who already are susceptible for developing psychotic symptoms."); Michael Rutter, Psychopathological Development Across Adolescence, 36 J. YOUTH ADOLESCENCE 101, 106 (2007) (discussing the potential beginning of severe mental illnesses such as schizophrenia in adolescence).

70 E.g., Lencz et al., supra note 63, at 578.

71 See TORREY, SURVIVING SCHIZOPHRENIA, supra note 12, at 143-44. 
crete data concerning both the genetic and environmental influences will become available. Once we fully understand the nature of severe mental illness, how it is caused and how we can treat or possibly cure it, the laws surrounding forced medication will undoubtedly change to reflect scientific advances.

\section{Cognition and Insight}

Deficits in attention and memory are an important cognitive feature of severe mental illnesses. Research suggests that persons with schizophrenia, for example, are "meaningfully impaired in real-world tasks that involve shifting attention in cluttered scenes. Tasks as mundane as scanning the TV listings for a preferred program or finding the right variety of soup on a shelf may require significantly more time and effort ...."72 This type of attention impairment makes it extremely difficult for a person with a severe mental illness to keep up with the daily pace of any type of employment. ${ }^{73}$

The level or lack of personal insight into a severe mental illness is critical to understanding why involuntary treatment is necessary to treat severe mental illnesses. Research suggests that about half of patients with severe mental illnesses lack the insight-awareness or understanding - that they suffer from mental illness. ${ }^{74}$ The implications of this for the law are critical since involuntary or forced treatment is a focus of many civil commitment statutes. Certainly, lack of insight means a lack of a requisite level of autonomy that is

72 Rebecca L. Fuller et al., Impaired Control of Visual Attention in Schizophrenia, $115 \mathrm{~J}$. ABNORMAL PSYCHOL. 266, 273 (all patients in the study were taking medication). See also Elyn R. SAKs, THE CENTER CANNOT HOLd: MY JouRnEY Through MADNESS 229 (2007) [hereinafter SAKS, THE CENTER CANNOT HOLD] (describing the chaotic feeling of having one's attention pulled in hundreds of directions, which is often an aspect of schizophrenia).

73 TORREY, SURVIVING SCHIZOPHRENIA, supra note 12, at 259 ("Estimates of the number of persons with schizophrenia capable of full-time work range as low as 6 percent ...."). An interactive Web site illustrates how a person suffering from schizophrenia faced with the simple task of filling a prescription in a drug store may become confused and disoriented upon hearing voices and seeing haunting figures that may lead to irrational behaviors. The Sights and Sounds of Schizophrenia (NPR broadcast 2002), available at http://www.npr.org/templates/story/story.php?storyId=1149147. Contra SAKS, THE CENTER CANNOT HOLD, supra note 72, at passim (describing how focusing on her work, and in her case, highly rigorous academic work, helped to keep her functioning in the world during critical periods of her struggle with schizophrenia; simultaneously, it helped to preserve her core identity outside of mental illness, which became like a life vest that kept her from sinking deeper into mental illness).

74 E. Fuller TORREY, OUT OF THE SHADOWS: CONFRONTING AMERICA's MENTAL ILlNESS CRISIS 154 (1997) [hereinafter TORREY, OUT OF THE SHADOWS]. In a study published by Xavier Amador and his colleges in New York, fifty-seven percent of persons with schizophrenia were unaware that they were psychiatrically impaired. Id. In a study published by Anthony David and his colleges at London's Institute for Psychiatry, forty-seven percent of patients had impaired insight into their illnesses. Id. See also XAVIER AMADOR, I AM Not Sick, I Don'T NEED HELP! 31-32 (2d ed. 2007) (describing how poor insight is a symptom of severe mental illness that is neurologically based). 
typically required to make a voluntary decision. ${ }^{75}$ Without autonomy, arguably, no truly free decision can be made. ${ }^{76}$ Studies have shown that the level of a severely mentally ill person's insight into his or her own illness is likely to vary based upon age, duration of the illness, and possibly the tendency toward the commission of violent acts. $^{77}$

\section{Violence}

Violent acts are typically the means by which the public hears about se-

75 See John StuarT Mill, ON LiberTy (Penguin Books 1974) (1859) (referring to such persons through a broader reading of his language). "Mill himself found nothing inconsistent in applying libertarianism only to those lacking a mental disorder." John Monahan, John Stuart Mill on the Liberty of the Mentally Ill, A Historical Note, 134 AM. J. PSYCHIATRY 1428, 1428 (1977) [hereinafter Monahan, Mill on the Liberty of the Mentally Ill].

Mill's general theory on autonomy is that a government may justifiably restrict an individual's autonomy only when the individual's actions or behavior poses a danger to other persons in society. MnL, supra note 75 , at $68-69,141-42,145,149$. This theory has typically been used to reinforce the policies of the danger-or-grave-disability statutes; thus, that the severely mentally ill should only be involuntarily treated when they are a danger to themselves or to others. E.g., Monahan, Mill on the Liberty of the Mentally Ill, supra note 75, at 1428. There are several explicit exceptions, however, to Mill's general theory on governmental paternalism that are sometimes overlooked. See id. For instance, Mill states that children, teenagers, persons "in a state to require being taken care of by others," and persons in a "backward state[] of society" are expressly excluded from the general rule that paternalistic action is justified only to prevent danger to others. MiLL, supra note 75, at 69. Professor Monahan points out that this exception may also be read as applying to those who lack "the maturity of their faculties" and are "in a state to require being taken care of by others." Monahan, Mill on the Liberty of the Mentally Ill, supra note 75, at 1428 (quoting MILL, ON LIBERTY, supra note 75, at 69). Therefore, the great libertarian himself, and his theory on the tension between governmental paternalism and individual autonomy, tend to create an exception that would permit involuntary treatment of the severely mentally ill even when they fail to pose a danger to others or to themselves.

76 See Jayne Breeze, Can Paternalism Be Justified In Mental Health Care?, 28 J. AdVANCED Nursing 260, 262 (1998) (citing T. L. BEAUChAMP \& J.F. CHILDRESS, PRINCIPLES OF BIOMEDICAL ETHICs (3d ed. 1989); Gerald Dworkin, Paternalism, in PHLOSOPHY OF LAW (2d ed.

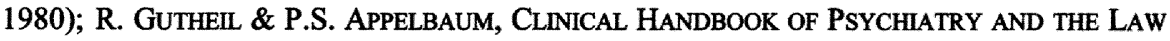
(1982)) (discussing "weak" or justified paternalism in the context of rational autonomy and how it can promote individual autonomy by restoring the missing element of rationality).

77 Some scientists argue that insight into a developing severe mental illness is best in the early stages of the disease's development. Under this theory, incremental damage to specific parts of the brain leads to decreased awareness overtime. TORREY, SURVIVING SCHIZOPHRENIA, supra note 12, at 51. Therefore, a person who is older and has had a severe mental illness for a longer period of time is more likely to suffer from greater lack of insight and will be less likely to seek voluntary treatment. See id. Other scientists argue, however, that individuals who lack the greatest insight into their severe mental illnesses are those more prone to violence: particularly, those who were arrested or committed a violent act in the previous year. Eric B. Elbogen et al., The Impact of Perceived Need for Treatment on Risk of Arrest and Violence Among People with Severe Mental Illness, 34 CRIM. JUST. \& BEHAV. 197, 206 (2007). 
verely mentally ill persons. The media attention surrounding the Virginia Tech massacre illustrates this phenomenon. ${ }^{78}$ But contrary to popular belief, many scientific studies have struggled to find a concrete link between violence and severe mental illness. ${ }^{79}$ The results of these studies range depending upon any of the following variables: the target diagnosis of the study; ${ }^{80}$ the particular symptoms reported (rather than diagnosis itself); ${ }^{81}$ the type of crime committed or studied; ${ }^{82}$ neurological data of the illness; geographic location of the study; ${ }^{83}$ prior hospitalizations; previous criminal conduct of the individual; the living

${ }^{78}$ Letters to the Editor, Virginia Tech Shootings; Media Attention Encourages Next Attack, Detrort Free Press, Apr. 23, 2007, at 14A.

79 See infra notes $80-95$.

${ }^{80}$ For example, researchers might study incidences of violence among schizophrenics, manic-depressives, or those suffering from major depression. One prominent study showed that persons with schizophrenia had lower rates of violence compared to those with bipolar disorder and depression. JOHN MONAHAN ET AL., RETHINKING RISK ASSESSMENT: ThE MACARTHUR StUdy of MENTAL Disorder AND Violence 64 (2001) [hereinafter MonaHAN ET AL., MACARTHUR STUDY]. After one year, those with bipolar and depression had a violence incidence rate of $22 \%$ and $28.5 \%$ (respectively), compared to those with schizophrenia who had a reduced rate of 14.8\%. Id.; but see TORREY, OUT OF THE SHADOWS, supra, at 74 (citing a 1994 English study that found a higher risk of violence among schizophrenic patients compared to controls with other psychiatric diagnoses); Patricia A. Brennan \& Amanda Alden, Schizophrenia and Violence: The Overlap, in CRIME AND SCHIZOPHRENIA: CAUSES AND CURES 25-26 (Adrian Raine ed., 2006) ("The weight of the evidence suggests a significant and large effect of schizophrenia on risk for violence.").

${ }^{81}$ Some studies suggest that the level or degree of a particular symptom may be the best predictor of violent behaviors rather than sheer clinical diagnosis. Skeem et al., Psychiatric Symptoms and Community Violence Among High-Risk Patients: A Test of the Relationship at the Weekly Level, 74 J. ConsUlting \& CliniCAL Psychol. 967, 968 (2006) (citing prior studies). A recent study challenged this hypothesis and found that average levels of hostility, rather than general distress or other symptoms (such as depression, anxiety, and thought control), of high risk patients discharged from inpatient hospitals (emergency rooms) was the best indicator of violence over a six month period. Id. at 972,974 (patients were monitored on a weekly basis). Hostility was measured as "feeling easily annoyed or irritated; temper outbursts that he or she could not control; having urges to beat, injure, or harm someone; having urges to smash things; and getting into frequent arguments." Id. at 973. Hence, deterioration in symptoms of depression, anxiety, or thought-control (often related with schizophrenia) did not correlate with an increased risk in violence in the short term, particularly on an arguably "imminent" weekly basis. See id. at 976 . The Skeem et al. study suggests that in order to reduce violence among the severely mentally ill, resources should be channeled to improve anger management and reduction. Id. at 977.

${ }^{82}$ For example, some researchers have studied the incidence of subway-pushings, which apparently seems to be a crime related primarily to those with mental illness. TORREY, OUT OF THE SHADOWS, supra note 74, at 46-47.

${ }^{83}$ One national study in the United States estimated that in 1992 persons with mental illness were responsible for 770 out of 23,000 homicides in the United States (roughly 3.3\%). TORREY, OUT OF THE SHADOWS, supra note 74, at 49 (noting that in Iceland, a country with an extremely low homicide rate, twenty-eight percent of its homicides were committed by mentally ill persons over an eighty year period). 
environment of the mentally ill individual ${ }^{84}$ and whether or not there is a diagnosis of a co-occurring substance abuse disorder. ${ }^{85}$

Some studies have shown that an increased level of psychotic symptoms may be the best predictor of the likelihood of committing a violent act. ${ }^{86}$ Other studies suggest that one important predictor of future violence among the severely mentally ill is non-adherence to medication. ${ }^{87}$ There is also evidence that a failure to provide effective treatment on an outpatient basis is another contributing factor to the incidence of violence with severe mental illness. ${ }^{88}$

One of the most prominent studies in the field, the MacArthur Study, suggests there is a link between violence and severe mental illness but cautions that it is complex, multi-faceted, and therefore difficult to clinically predict. ${ }^{89}$ The study followed roughly one thousand severely mentally ill individuals after discharge from inpatient hospitals and measured their rates of violence at two key intervals: at the initial five month mark after release and at the full year mark after release. ${ }^{90}$ For persons with schizophrenia, bipolar disorder, and depression, the one year rate of violence post discharge was $17.9 \%$ compared to a lower $10.1 \%$ after the first five months post discharge. ${ }^{91}$ Hence, the longer time after discharge - the greater the distance from the time intensive treatment is administered - the more likely violent acts were to be committed. ${ }^{92}$ The MacArthur Study also challenged (inadvertently) the reliability of single categorical correlations between delusions, hallucinations, anger, or violent thoughts and violent acts by severely mentally ill individuals. ${ }^{93}$

While most individuals suffering from a severe mental illness are not violent, researchers tend to agree that a small percentage seem to have a violent propensity. ${ }^{94}$ Nonetheless, there fails to be a magic bullet study linking any particular risk factor or symptom of any particular severe mental illness with

${ }^{84} I d$. at 47 (including whether or not the individual is living with a non-mentally ill family member at the time).

${ }^{85}$ Compare id. at 48 (citing a Swedish study that found severely mentally ill men and women were 4.2 and 27.5 times more likely, respectively, to have committed a violent crime compared to controls) with Skeem et al., supra note 81, at 967 ("[T] he nuances of the relationship between mental disorder and violence remain elusive.").

${ }^{86}$ TORREY, OUT OF THE SHADOWS, supra note 74, at 46 (regarding a study conducted in 1992 by Bruce Link and his colleagues at the New York State Psychiatric Institute).

${ }_{87}^{87}$ E.g., id. at 50.

88 Id. at 53-54.

89 MONAHAN ET AL., MACARTHUR StUdy, supra note 80, at 142 ("Perhaps unsurprisingly, the complexity of human behavior has thus far frustrated . . . attempts to find unitary causes of and solutions to violen[t acts committed by severely mentally ill individuals].")

90 Id. at 63-64, 64 tbl.4.1.

91 Id.

92 See id.

93 Id. at 77, 80, 85, 89 (arguing, however, that such symptoms are still important factors to consider when predicting violence among the severely mentally ill).

94 See, e.g., TORREY, SURVIVING SCHIZOPHRENIA, supra note 12, at 306. 
future violent acts. ${ }^{95}$

\section{E. Medication and Other Forms of Treatment}

Today, medication is the primary course of treatment for severe mental illnesses. Schizophrenia, for example, "[c]ontrary to the popular stereotype, is an eminently treatable disease" 96 even though the cause and cure are still unknown. ${ }^{97}$ Schizophrenia is also a chronic mental illness, so even though treatment measures are available, it tends to be a lifelong illness that never fully disappears even with the most successful treatments. ${ }^{98}$ While medication has proven to be the most effective treatment for schizophrenia, ${ }^{99}$ and in turn dramatically improves the quality of life for such individuals, ${ }^{100}$ it is not the only treatment available. Psychotherapy, ${ }^{101}$ cognitive behavioral therapy, electro-

95 Id. Even so, the MacArthur Study is widely known for having offered practitioners a multi-variable risk assessment tool that has since been used by many researchers in predicting future acts of violence by severely mentally ill individuals. See MONAHAN ET AL., MACARTHUR STUDY, supra note 80 , at 113 . It is described by its authors as an "interactive and contingent model of violence, one that allows many different combinations of risk factors to classify a person as high or low risk." Id. (including clinical variables, such as diagnosis, delusions, psychopathy, violent thoughts, and hallucinations, and criminological variables, such as prior violence and criminality, gender, neighborhood, and child experiences). The MacArthur Study reports that

no single intervention is likely to enable the successful management of potential violence. Multiple targets for intervention will exist, and they will differ from person to person. The multivariate interactive causal model of violence that is most consistent with our data ... implies that effective interventions need not eliminate all or even most of a person's risk factors. It should be sufficient only to reduce the presence of these factors below the threshold ... at which their combined effect is likely to cross the threshold at which violence occurs.

Id. at 143 . The 2006 study undertaken by Skeem et al., like many prominent studies in the field, employed the MacArthur actuarial risk assessment tool. Skeem et al., supra note 81, at 969, 976.

96 TORREY, SURVIVING SCHIZOPHRENIA, supra note 12, at 156.

97 "Successful treatment means the control of symptoms, whereas cure means the permanent removal of their causes." Id.

98 See, e.g., Michelle Kramer et al., Paliperidone Extended-Release Tablets for Prevention of Symptom Recurrence in Patients With Schizophrenia: A Randomized, Double-Blind, Placebo-Controlled Study, 27 J. ClinICAL PsYchophaRMACOLOGY 6, 6 (2007). See also SAKS, REFUSING CARE, supra note 18 , at 51 ("[S]ome mentally ill people . . . are treatable to only a modest degree.").

99 TORREY, SURVIVING SCHIZOPHRENIA, supra note 12, at 196, 199 (stating that studies show approximately seventy percent of persons with schizophrenia significantly improve if they take first generation antipsychotics, such as chlorpromazine or Thorazine).

100 Cf. Jeanette Hewitt, Critical Evaluation of the Use of Research Tools in Evaluating Quality of Life for People with Schizophrenia, 16 INT'L J. MENTAL HEALTH NURSING 2, 2 (2007) (describing tools for measuring the quality of life for severely mentally ill individuals including independence, the absence of pain, and the ability to be physically active).

101 Paul H. Lysaker et al., Psychotherapy and Recovery in Schizophrenia: A Proposal of 
convulsive therapy, and nutritional treatments often supplement and enhance medication-based treatments of schizophrenia. ${ }^{102}$ Further, most of the antipsychotic medications used to treat schizophrenia only help to treat the positive symptoms and so medication should be supplemented with other forms of treatment to help cope with the negative and cognitive symptoms of the disease. ${ }^{103}$

One of the major problems with medication as a form of treatment for severe mental illness is ensuring that the patient adheres to the medication, which is sometimes also related to lack of insight into the illness. In many cases, patients may begin to feel better once regularly taking medication and decide to stop taking it precisely because they feel they have recovered. In other cases, patients who experience side effects, such as movement disorders, ${ }^{104}$ weight gain, ${ }^{105}$ or sexual dysfunction eventually stop taking their medication in order to

Key Elements for an Integrative Psychotherapy Attuned to Narrative in Schizophrenia, 4 PSYCHOL. SERVS. 28, 35 (emphasizing the need for psychotherapy and developed narratives as part of the treatment course for schizophrenia); SAKS, REFUSING CARE, supra note 18, at 119; SAKS, THE CENTER CANNOT HOLD, supra note 72, at 185, 187-88 ("Psychoanalytical treatment kept me out of the hospital while I actually completed my Oxford degree.").

102 E.g., TORREY, SURVIVING SCHIZOPHRENIA, supra note 12, at 184-94. See also DUKAKIS \& TYE, supra note 10 (discussing the therapeutic benefits of ECT).

103 P.F. Buckley \& S.M. Stahl, Pharmacological Treatment of Negative Symptoms of Schizophrenia: Therapeutic Opportunity or Cul-de-sac?, 115 ACTA PSYCHIATRICA SCANDINAVICA 93, 94 (2007). Recent research suggests that a new drug may treat both negative and positive symptoms of schizophrenia. Sandeep T. Patil et al., Activation of mGlu2/3 Receptors As a New Approach to Treat Schizophrenia: A Randomized Phase 2 Clinical Trial, 13 NATURE MED. 1102 (2007); see also Alex Berenson, New Schizophrenia Drug Shows Promise In Trials, N.Y. TIMES, Sept. 3, 2007, at A9.

Additionally, recent evidence suggests that the use of antidepressants to treat the negative symptoms of bipolar disorder is ineffective, leading researchers to believe that better treatment for this disorder may lie in the use of antipsychotics. Karen Augé, Antidepressants Fail in Bipolar Test, DENV. Post, Mar. 29, 2007, at A19 (citing the results of a seven year study recently released and funded by the National Institutes of Health surveying twenty-two sites across the country and roughly five thousand bipolar patients).

104 Kramer et al., supra note 98, at 6; McCreadie, supra note 64, at 21, 24 (describing two types of movement disorders: 1) parkinsonian side-effects such as tremor and rigidity, which usually require prescription of anti-parkinsonian medication and 2) tardive dyskinesia that may result in abnormal movements of the face).

105 Another criticism of the use of medication as the primary form of treatment for severe mental illnesses is that side-effects, such as weight gain, may lead to other medical and public health issues for this population. Indeed, some studies have indicated a possible link between the use of second generation antipsychotics and the development of adult obesity and diabetes, conditions which raise other serious medical concerns. Christopher Reist et al., SecondGeneration Antipsychotic Exposure and Metabolic-Related Disorders in Patients with Schizophrenia: An Observational Pharmacoepidemiology Study From 1988 to 2002, 27 J. CLINICAL PSYCHOPHARMACOLOGY 46, 49, 50 (2007). See also Jose de Leon, Weight Gain During a Double-Blind Multidosage Clozapine Study, 27 J. ClinICAL PsychopHARMACOLOGY 22, 22 (2007) (noting that the incidence in weight gain is higher with the medication clozapine compared to olanzapine but suggesting that "base-line [body mass index], dosing, and, possibly, the AfricanAmerican race may be major determinants of clozapine-induced weight gain."). 
avoid the side effects. This type of self-administered drug withdrawal can be very dangerous for persons with severe mental illnesses because there is some evidence that psychiatric medications are less effective after a patient has withdrawn from them. ${ }^{106}$ Nonetheless, recent studies show that newer, secondgeneration antipsychotics have fewer side-effects than first-generation antipsychotics. $^{107}$

Other researchers are looking for ways to ensure that the very form and chemical structure of a medication helps to improve treatment adherence. ${ }^{108}$ For example, extended-release tablets ${ }^{109}$ and depot injections ${ }^{110}$ have been used as alternatives to taking daily oral pills. With depot injections, the patient may be required to report to an outpatient facility where a provider will inject the medication on a bimonthly or monthly basis depending on the medication. ${ }^{111}$ The injection method has been criticized, not only because it can lead to prolonged pain at the injection site, but also because the injection remains in the bloodstream for roughly two weeks. ${ }^{112}$ Consequently, patients utilizing the injection method are unable to avoid the negative side-effects once the injection has been administered. New research suggests that small biodegradable devices

106 Some studies show that providers need to be careful when lowering the dose of antipsychotic medication for a patient "below the level to which the patient initially responded," because the lower administered dosage may lead to a relapse or problems with future treatment. E.g., I. Lipkovich et al., Predictors of Risk for Relapse in Patients with Schizophrenia or Schizoaffective Disorder During Olanzapine Drug Therapy, 41 J. PSYCHIATRIC RES. 305, 309 (2007). In general, "[r] elapse has been attributed to a variety of factors, including poor compliance with antipsychotic drug therapy, inadequate dosing, residual psychopathology, poor insight into the illness and need for treatment, comorbid substance abuse and poor relationships between patients, families and care providers." Id.

107 E.g. TORREY, SURVIVING SCHIZOPHRENIA, supra note 12, at 216 (noting fewer Parkinsonian-like symptoms in particular). Clozapine, a key second-generation antipsychotic, was first introduced to the U.S. in 1990. See id. at 197, 219-20. See also Peter Malik, Sexual Dysfunction in Schizophrenia, 20 CURRENT OPINION IN PSYCHIATRY 138, 141 (2007) (showing reduced sexual side effects in second generation antipsychotics).

108 Contrary studies suggest that the best predictor of whether or not a severely mentally ill individual adheres to medication is a care provider's genuine explanation of how and why the individual needs to take the medication. $C f$. Richard Gray et al., Adherence Therapy for People with Schizophrenia, 189 BRIT. J. PSYCHIATRY 508, 508-09, 511 (2006) (concluding that directly involving patients in understanding their medication had roughly an equal adherence rate with broader general health education).

${ }^{109}$ Kramer et al., supra note 98, at 6, 12 (2007) (discussing the positive findings of the twenty-four hour drug release tablets).

110 Kayla L. Metzger et al., Pharmacokinetic and Behavioral Characterization of a LongTerm Antipsychotic Delivery System in Rodents and Rabbits, 190 PSYCHOPHARMACOLOGY 201, 202 (2007).

111 See ToRrey, SURVIVING SCHIZOPHRENIA, supra note 12, at 199. Patients not reporting to an outpatient facility may be required to self-administer the injections roughly twenty-four times a year. Metzger et al., supra note 110, at 202.

112 Metzger et al., supra note 110, at 202. 
may also be used to physically implant psychiatric medication into the body. ${ }^{113}$ Such a device would be surgically implanted, and therefore, at the first sign of a negative side-effect it could be immediately (surgically) removed. ${ }^{114}$ Medication administered in this manner would remain effective for up to six months (and would be biodegradable), assuming that the onset of negative side-effects did not necessitate its removal. ${ }^{115}$

It should also be noted that recent improvements in the tools of diagnostic medicine, such as history and mental status examinations, physical and neurological examinations, blood count and urinalysis, psychological tests, MRI and CT scans, lumbar punctures, and EEGs have made diagnosing severe mental illnesses much easier today. ${ }^{116}$ Some studies even suggest that brain scans taken of individuals with a family history of diseases, such as schizophrenia, may be able to predict whether the individual is likely to develop the disease before any negative onset. ${ }^{117}$ Understanding the current medical nature of severe mental illnesses is critical because it reveals the truth as to how mental illnesses operate and helps those in the legal field determine how to draw the appropriate balance between civil liberties, public and private health, and protecting citizens from harm.

\section{ROBERT'S STORY: A HUMAN FACE TO THE FAILURES OF THE DANGER- OR-GRAVE-DISABILITY STATUTES}

Meet Robert. ${ }^{118} \mathrm{He}$ is forty-seven years old and was diagnosed with paranoid schizophrenia twenty years ago. ${ }^{119} \mathrm{He}$ has been homeless for roughly the

113 Id.

114 Id.

115 Id. at 202, 206-07 (noting that it may take up to two weeks for the medication to begin to work, which is also typical of other forms of medication).

116 TORREY, SURVIVING SCHIZOPHRENIA, supra note 12, at 162-66. See also PAUL L. WEGKAMP, JR., THE NORTHUMBERLAND NIGHTMARE: WHEN JUSTICE IGNORES MENTAL ILLNESS 95 (2004) ("The [CT] scan shows that Chad has neurological damage in the form of enlarged cerebral ventricles. ... The cavities become enlarged because of the loss of brain tissue, putting pressure on the brain.").

117 Bridget M. Kuehn, Brain Scan May Predict Schizophrenia, 297 J. AM. MED. Ass'N 253, 253 (2007). These brain scans focus on the theory that "a reduction of the brain's gray matter precedes the onset of schizophrenia." Id.

118 Robert Gilmore is one of the mentally ill individuals on Doctor E. Fuller Torrey's "preventable tragedies" Web site. Dr. Torrey, one of the leading activists of PVOT, keeps a Web site of preventable tragedies that have occurred in the United States from 1987 to the present date. Treatment Advoc. Ctr., "Preventable Tragedies" Database Search, http://www.psychlaws.org/ep.asp (last visited Feb. 18, 2006). At least 3,000 deaths have occurred since Dr. Torrey and the Treatment Advocacy Center starting keeping tally of incidents from various statewide news articles. Id. Nonetheless, each of these deaths is somehow related to a diagnosed mentally ill individual who remained untreated in the community. Id.

119 Id. 
same period of time. ${ }^{120}$ Robert has also been arrested more than forty times. ${ }^{121}$ The charges are generally for wandering onto public property, urinating in public, or disobeying an officer. ${ }^{122}$ His family continually offers him shelter, finances, and care, but he repeatedly declines such offers and chooses to live on the streets, alone. ${ }^{123}$ Robert is not receiving any treatment for his paranoid schizophrenia. $^{124}$

Recently, Robert was arrested when asked to leave a municipal parking garage in his hometown in Kansas, presumably for seeking shelter from the winter cold. ${ }^{125}$ He struck a police officer when asked to leave and was taken to jail. ${ }^{126}$ His mother and brother picked him up upon his release but Robert declined their financial and housing assistance yet again. ${ }^{127}$ Robert chose to return to the streets, without any income, companionship, or stable shelter, instead accompanied by his untreated symptoms of paranoid schizophrenia. ${ }^{128}$

\section{A. Robert's Chances for Treatment Under A Typical Danger-or-Grave- Disability Statute}

Robert's violent action of striking a police officer (when being asked to leave the public parking garage) fails to meet the threshold of most variations of the danger-or-grave-disability statutes. Striking a police officer with a fist is not a threat of "imminent" substantial bodily harm or death or a "substantial risk" that it might occur. Likewise, Robert's chronic homelessness does not meet either the "gravely disabled" or the imminent "danger of harm to self" standard. These statutory provisions would likely only help Robert obtain involuntary treatment if he began to manifest signs of severe malnutrition or malfunction. This is premised on someone discovering Robert and reporting him to an officer, by which time it may be too late.

Many would argue that Robert's paranoid schizophrenia has taken hold of his life and liberty during at least twenty years of his life. Notice that his family, though arguably the most reliable witnesses to the development of his disease, has been unable to help him get the treatment he needs, even though he is chronically homeless and severely mentally ill. One way of thinking of this predicament is that it is Robert's mental illness, and not Robert himself, that has controlled his ability to comprehend the nature of his illness as it has grown

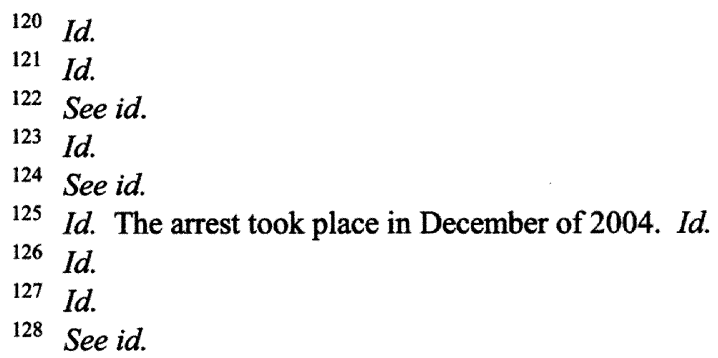


into him over the last twenty years. ${ }^{129}$ Each year, he loses more insight and grows into the illness even further. Schizophrenia has disordered his thinking and his very ability to consent to the point that he does not recognize that he needs help.

Through the application of Robert's case to the "danger or grave disability" statutes, one can see that the public policy of these statutes is that Robert should be free to live homeless though he is also diagnosed with a severe mental illness, is in need of medical treatment, and has been arrested forty times for misdemeanor violations. This public policy trusts the severe mental illness over the medical and scientific evidence that his illness has impaired his very ability to consent.

\section{B. Robert's Chances for Treatment Under a PVOT Statute}

Two factors make Robert an excellent candidate for treatment under a PVOT statute: his chronic condition and prior criminal record. The facts show that Robert has been chronically homeless for twenty years and has had forty misdemeanor violations. Medical and criminal history are two of several factors considered when determining whether Robert is an eligible candidate for PVOT. ${ }^{130}$ Additionally, under a PVOT statute, aside from a police officer making an arrest, Robert's parents or siblings could petition the court to have a mental health professional examine his condition, and the professional would then make recommendations to the court about a specific treatment regimen for him. If a court found that Robert was a proper candidate for PVOT by the traditional clear and convincing evidence standard, they could order him to begin taking medication. He might also be required to start meeting with doctors, social workers, and vocational counselors regularly to get him back to the point where he is able to function in society and begin to make some independent and arguably autonomous decisions ${ }^{131}$ in his life.

In summary, involuntary outpatient commitment through a PVOT statute has the power to give Robert-a non-violent but severely mentally ill homeless individual - his liberty back as opposed to fostering neglect for an illness that is destroying his personality and dignity. With medication, Robert may hold a job, find meaningful relationships, or live in a home of his own someday. The options of meaningful choices and lifestyles are greatly enhanced. ${ }^{132}$

129 TORREY, SURVIVING SCHIZOPHRENIA, supra note 12, at 51. See supra note 77 and accompanying text (discussing insight).

${ }^{130}$ See infra Part V.

131 See Stephen Darwall, The Value of Autonomy and Autonomy of the Will, 116 ETHICS 263,265 (2006) (identifying four types of autonomy one of which is rational autonomy). See also supra note 75 and accompanying text (discussing paternalism).

132 Contra Margo Flug, No Commitment: Kendra's Law Makes No Promise of Adequate Mental Health, 10 GEO. J. ON POVERTY L. \& POL'Y 105, 108-09 (2003) (arguing that PVOT is coercive and restricts liberty interests of mentally ill individuals). 


\section{THE LANGUAGE OF THE MODEL PVOT STATUTES: KENDRA'S LAW AND LAURA'S LAW}

The two primary PVOT statutes currently in existence are those of New York and California: Kendra's Law and Laura's Law, respectively. Each law takes the name of an innocent-bystander victim who was killed as a result of the impulsive and violent actions of chronically mentally ill individuals who remained untreated in the community, though family members had tried for years to obtain treatment for them. Kendra Webdale, an aspiring writer in her earlythirties, was killed by a man suffering from schizophrenia who randomly pushed her off a New York subway platform and into an oncoming train. ${ }^{133}$ Laura Wilcox, a nineteen-year-old, was killed by an individual diagnosed with schizophrenia in a random-fire shooting along with two other innocent victims. ${ }^{134}$ Though similar to one another in form, Kendra's Law and Laura's Law each represent slightly different policy positions on PVOT. Since their enactment, several other jurisdictions have sought to adopt similar legislation. ${ }^{135}$

One unifying concept, among others that will be discussed in more detail below, is that treatment plans under PVOT statutes typically start with an initial six months of forced treatment and are available for renewal depending upon the patient's progress. ${ }^{136}$ Hence, they are unique compared to other AOT stat-

133 Kendra Webdale was killed by Andrew Goldstein, a twenty-nine-year-old jobless, college dropout "who had a history of schizophrenia and violent assaults." Fritz, supra note 8, at A12. A unique factor in Kendra's case was that Andrew Goldstein " voluntarily sought commitment or supervised living thirteen times prior"' to killing Kendra ... but due to lack of resources, such as hospital beds, he was refused adequate treatment each time. Flug, supra note 132, at 111-12 (quoting a New York state report on quality care for the mentally ill).

134 Laura Wilcox was the youngest of the victims when in 2001 "a deranged catfish farmer went on a rampage in a small Northern California town, killing three people and igniting public outrage." Fritz, supra note 8, at A12.

${ }^{135}$ See infra Part VI.

136 Compare Laura's Law, CAL. WELF. \& INST. CODE § 5346(g), (h) (West Supp. 2007) (stating that the initial order is not to exceed 180 days but every sixty days the director of the PVOT program shall file an affidavit affirming that the person still meets the PVOT criteria at which time the person subject to the PVOT commitment has a right to a hearing) with Kendra's Law, N.Y. MENTAL HYG. LAw $\S 9.60(j)(2)$, (k) (McKinney 2006) (stating that the initial treatment period of PVOT shall not exceed six months; petitions for additional periods of treatment must be made within thirty days prior to expiration of the PVOT order in which the court may order PVOT for a further period not to exceed one year). New York's Kendra's Law permits for an arguably more stable and longer lasting treatment period compared to California's Laura's Law.

One of the key reasons that a lengthier initial treatment period is used in PVOT statutes is that medication does not always instantly become effective once it is taken. TORREY, SURVIVING SCHIZOPHRENIA, supra note 12, at 204. "On one end of the clinical spectrum are individuals who respond dramatically within forty-eight hours of being started on medication, whereas on the other end are individuals who respond very slowly over several months." Id. In one prominent study of first-episode patients with schizophrenia, the mean interval between starting medication and achieving the estimated maximum clinical improvement was thirty-five 
utes, including danger-or-grave-disability statutes, which typically only permit an initial, brief "seventy-two hour hold," 137 followed by further holds only so long as the danger-or-grave-disability criteria continue to be met. Therefore, under the danger-or-grave-disability statutes, many severely mentally ill persons are released back into the community too soon because they fail to continue to meet the danger-or-grave-disability criteria during the first seventy-two hour hold. Failure to meet commitment criteria might occur if a medication begins to work during the brief hold, or in the alternative, moods, psychotic breaks, or emotions cool. PVOT statutes address this problem directly by providing for lengthier initial treatment periods.

Understanding the different policy approaches taken through the specific language of Kendra's Law and Laura's Law will help shed light on the kinds of choices that legislatures and public policy makers have when deciding whether or not to implement PVOT. At the same time, this analysis will highlight the general goals and primary functions of PVOT statutes.

\section{A. Kendra's Law of New York}

\section{Eligibility Requirements}

Kendra's Law ${ }^{138}$ requires that seven evidentiary elements each be met by clear and convincing evidence ${ }^{139}$ in order for a person to receive PVOT in the state of New York. ${ }^{140}$ Each of the seven elements is distinct and detailed. Additionally, the very nature of requiring seven separate prima facie evidentiary elements to trigger PVOT eligibility suggests the statute is narrowly drawn and that its scope targets a specific population of severely mentally ill individuals. The seven statutory elements for PVOT treatment eligibility are as follows.

First, in order to be eligible for PVOT the mentally ill individual must be at least eighteen years old. ${ }^{141}$ Therefore, children and teenagers are not subject to Kendra's Law. Second, the individual must be "suffering from a mental ill-

weeks, or roughly nine months, though half of the patients had achieved maximum improvement by eleven weeks, or roughly three months. $I d$. (citing a study conducted by Dr. Jeffrey Lieberman and his colleagues). The initial six month commitment order under PVOT statutes therefore is medically critical to assisting severely mentally ill persons in making genuine headway toward recovery.

137 See generally BEBE MOORE CAMPBELL, 72 HOUR HOLD passim (2005) (illustrating through fiction a parent's struggle to obtain treatment for an adult child under California's danger-or-grave-disability statute, the Lanterman-Petris-Short Act).

${ }^{138}$ Kendra's Law, N.Y. MENTAL HYG. LAW $\S 9.60$ (McKinney 2006). Kendra's Law became effective in 1999 and currently has a sunset provision in 2010 (unless amended or deleted before that date). Id. See also Kendra's Law, ch. 408, 1999 N.Y. Laws 2870 (codified at N.Y. MENTAL HYG. LAW $\S 9.60$ ).

139 Id. $\S 9.60(\mathrm{j})(2)$.

140 See id. $\S 9.60(\mathrm{c})(1)-(7)$.

141 Id. $\S 9.60(\mathrm{c})(1)$. 
ness . . .."142 This determination requires a clinical diagnosis by a mental health provider. Nevertheless, it should be noted that the severity of the mental illness is not at issue for this criterion; all that is required is a diagnosis of a mental illness that presumably causes the person to suffer in some respect. Third, the individual must be "unlikely to survive safely in the community without supervision, based on a clinical determination ...."143 This provision gives power to the medical professional to determine whether the individual is capable of living safely on his or her own. Concomitantly, the criterion targets the severity of the illness as it focuses on whether "supervision" is needed in order for the individual to "survive safely."144

Fourth, the individual must have a "history of lack of compliance with treatment for mental illness" that has manifested itself in one of two situations, not including any incident within the most recent six months: ${ }^{145} 1$ ) psychiatric hospitalization or receipt of psychiatric services in a correctional facility at least twice within the last three years; ${ }^{146}$ or 2) at least one act of, threat of, or attempt at, "serious physical harm to self or others" within the last four years. ${ }^{147}$ The second prong of the fourth criterion is similar to the danger statutes. Yet, terms such as "threat of" or "attempt at" move away from the immanency-type standards typically required of the danger statutes. So albeit similar, this broadens the scope of what would traditionally be considered evidence under a dangeror-grave-disability statute.

The first prong of the fourth criterion, however, is more clearly a movement away from the danger-or-grave-disability statutes into new civil commitment territory. The first prong considers the medical history of the illness but further limits this into three subcategories that each must be present for the evidence to be admissible: 1 ) the medical history must be confined to either inpatient psychiatric hospitalization or receipt of psychiatric services in jail or prison, 2) that such medical history is only considered within the most recent three year period, excluding the most recent six months (excluding any receipt of services administered on the single incident that led to the civil commitment order), and 3) that there are at least two separate incidents (excluding the most recent six months) of psychiatric treatment in these physical environments. So while on the one hand the introduction of medical history of the illness seems to be a broad expansion away from the danger-or-grave-disability statutes, the his-

142 Id. $\$ 9.60(\mathrm{c})(2)$.

${ }^{143} I d$. $\S 9.60(\mathrm{c})(3)$. One critic has argued that "unlikely" to survive in the community may be a vague substitute for a "competency" determination. Gutterman, supra note 10 , at 2437.

${ }_{144}$ In many senses, this sounds like the gravely-disabled prong of the danger-or-gravedisability statutes. In time, how broadly or narrowly this criterion will be interpreted by the courts will show us how similar or different it is in function from the grave-disability prong.

145 N.Y. MENTAL HYG. LAW § 9.60(c)(4).

146 Id. $\S 9.60(\mathrm{c})(4)(\mathrm{i})$.

147 Id. $\$ 9.60(\mathrm{c})(4)(\mathrm{ii})$. 
tory is limited to a narrow population of mentally ill individuals: those who have been physically hospitalized or incarcerated. Hence, receipt of medication through an outpatient treatment plan, even under a danger-or-grave disability statute, would not be admissible evidence. This is a weakness of the statute as it fails to protect a larger population of severely mentally ill individuals who may not have received medication in an inpatient facility (quite possibly due to the lack of availability of a bed in a hospital or the public policy of pursuing outpatient over inpatient treatment) or while incarcerated. Nonetheless, a virtue of this criterion is that it seems to narrowly target a specific population of severely mentally ill individuals: those who are typically incarcerated or physically hospitalized for their illness. ${ }^{148}$

Fifth, the individual, "as a result of his or her mental illness [must be] unlikely to voluntarily participate in outpatient treatment that would enable him or her to live safely in the community ...."149 This criterion asks whether the individual lacks sufficient insight into his or her illness and therefore would not voluntarily submit to treatment. Sixth, in view of the individual's history and current behavior, the individual must be in need of PVOT to "prevent a relapse or deterioration which would be likely to result in serious harm to the person or others ...." While this criterion also rings similar in tone to the danger statutes, the word "likely" arguably reduces its burden; hence imminent or actual harm is not required. Seventh, and finally, the individual must be "likely to benefit from ... [PVOT]."

The absence of any one of these seven factors by a clear and convincing evidence standard denies PVOT eligibility. ${ }^{152}$ Certainly, far more power is given to the medical professional in helping the court determine whether the civil commitment should be ordered since much of the focus of the statutory language is on the severity of the illness and various ways it might manifest itself. But Kendra's Law is a middle ground approach as there is still a high evidentiary burden built into the statute. The combination of medical and legal limitations in the eligibility criteria makes Kendra's Law one that will likely only be considered by attorneys in cases in which a severe and persistent mental illness is at issue.

The fourth criterion of Kendra's Law seems to be one of the most critical requirements that deserves further discussion. The requirement focuses on the individual's history of mental illness and the extent to which it has manifested

148 See Kendra's Law, ch. 408, 1999 N.Y. Laws 2870 (codified at N.Y. MENTAL HYG. LAW $\S 9.60$ ) ("The legislature finds that there are mentally ill persons who are capable of living in the community with the help of family, friends and mental health professionals, but who, without routine care and treatment, may relapse and become violent or suicidal, or require hospitalization.")

149 N.Y. MENTAL HYG. LAW $§ 9.60(c)(5)$.

${ }^{150} I d . \S 9.60(\mathrm{c})(6)$.

151 Id. $\S 9.60(\mathrm{c})(7)$.

152 Id. $\S 9.60(\mathrm{j})$. 
itself in prior hospitalization, forced medication while in jail, or prior acts of violence. It permits events dating back to a maximum of three years for hospitalization and four years for violence to be used as evidence in the petition for treatment-but it goes no further. ${ }^{153}$ Hence, the nature of this criterion is such that it is likely to effectively distinguish between severely mentally ill persons and those persons who suffer from more minor conditions of mental illness. Certainly, there are many "mentally ill" persons who have not been hospitalized or incarcerated as a result of their illnesses. Kendra's Law does not seek to force treatment on such persons. Instead, the fourth criterion seeks to identify an emerging pattern of symptoms in those chronically and severely mentally ill persons, while additionally balancing civil liberties of the subpopulation by not permitting evidence of the illness dating back further than either three or four years, depending on the provision being applied. ${ }^{154}$

To understand better how Kendra's Law might screen out certain nonseverely-mentally-ill individuals, and further illustrate the intricacies of the fourth criterion, it may be useful to consider the story of Robert Gilmore again (the homeless forty-seven-year-old who suffers from paranoid schizophrenia). ${ }^{155}$ Depending on the circumstances, it is possible that even Robert would not be eligible for PVOT under Kendra's Law. Though we know Robert has been arrested in his hometown forty times in the last twenty years, we do not know how many arrests he has had within the last three years that have resulted in incarceration or hospitalization (excluding the most recent six months, which would include his striking a police officer that led to the most recent arrest). This is the critical question under Kendra's Law. Let us assume that his eligibility hinges on the first prong of the fourth criterion (two incidents of receipt of psychiatric services in a hospital, jail, or prison). ${ }^{156}$ Assuming this, either one of two scenarios must have occurred in his recent past for him to be eligible for PVOT under Kendra's Law.

The first is that, to be eligible for PVOT, Robert must have been incarcerated on two separate occasions within the past three years that each resulted in receipt of medication, excluding the most recent six months. This is not easy to establish unless one is severely mentally ill and has been incarcerated. Being

153 For details on the application of this criterion under New York Law see In re Dailey, 713 N.Y.S.2d 660, 662-63 (N.Y. Sup. Ct. 2000) (regarding inpatient hospitalization). See also

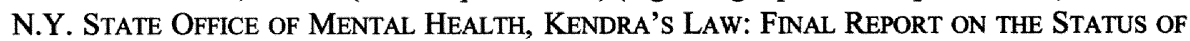
ASSISTED OUTPATIENT TREATMENT app.2 at 45-47 (2005).

154 Contra Gutterman, supra note 10, at 2434-35 ("Civil libertarians and patients' rights advocates vigorously oppose outpatient statutes, such as Kendra's Law ... They fear that such legislation is nebulous because it fails to delineate clear criteria for outpatient commitment, and will ultimately restore high rates of inpatient commitment.").

${ }^{155}$ See supra Part IV.

156 Since he was not a "danger to himself or others" when striking a police officer, this aspect of the fourth criterion is not discussed. See id. 
arrested but not incarcerated will not meet the criterion. ${ }^{157}$ Further, in Robert's case it is certainly possible that he was not medicated on any of the forty occasions he was arrested and incarcerated (and this is assuming he was taken to jail upon arrest and there was a need to medicate). But if Robert had been medicated under such circumstances, Kendra's Law asserts this would be highly probative of his deteriorating and unstable condition. Seen in this light, the first prong has established a high evidentiary standard that protects the liberty interests of non-severely mentally ill individuals who are not in need of PVOT. Even someone like Robert might not be considered severely ill enough, although he has been homeless for twenty years due to his illness and has been arrested forty times. Therefore, an inherent weakness of Kendra's Law is that, under certain circumstances, it may require literal "criminalization of the mentally ill" before it will step in to assist severely mentally ill persons. In light of this type of policy consideration, state legislatures might consider omitting the actual incarceration-coupled with forced medication-requirement of Kendra's Law and supplementing a requirement of high incidence of arrest, possibly even for misdemeanor crimes that result in a fine or ticket.

Second, in alternative to the first option described above, Robert must have been hospitalized (either by voluntary or involuntary means) twice within the last three years, excluding the most recent six months. Clearly, this standard of proof is not analogous to an individual who seeks out counsel or medication from a psychiatrist, general practitioner, or psychoanalyst, independent of hospitalization. Nor is it analogous to an individual who meets with a psychiatrist in his or her office upon an outpatient basis. Hence, accepting medication based on a voluntary doctor-patient relationship outside of a hospital setting is not the type of evidence that would ever meet this burden. The nature of this aspect of the fourth criterion relies inherently on the existing danger-orgrave-disability statutes. Thus, a critique of this provision is that it requires a nearly impossible threshold for the state to meet since most danger-or-gravedisability statutes require actual, imminent, or substantial risk of harm or extreme grave disability.

Nonetheless, a strength of the eligibility requirements under Kendra's Law is that it seeks to protect the liberty interests of severely mentally individuals to a high degree. It is very conservative in its willingness to depart from the danger-or-grave-disability statutes. Provisions that do diverge from the dangeror-grave-disability statutes seem to be highly cautious in their initial construction. The general requirement of three or four years of medical history that results in forced medication (an oversimplification) also fails to address younger individuals who may be developing a severe mental illness. Kendra's Law requires, in effect, that the individual continue to deteriorate for at a minimum of

157 It is also possible that some arrests that might typically result in jail time (at least awaiting trial) are waived because the police officer has past experience with the individual and knows he or she is severely mentally ill. 
three years before being willing to step in with a PVOT treatment plan. Medical research shows, however, that those who begin manifesting signs of a severe mental illness have the greatest chances for recovery if they receive treatment at earlier stages. ${ }^{158}$ Yet, Kendra's Law generally targets an older age bracket of those suffering from severe mental illnesses. ${ }^{159}$ Nonetheless, because Kendra's Law's seven eligibility criteria comprise a difficult legal burden to establish, Kendra's Law addresses a narrowly defined group of severely mentally ill individuals.

\section{Third Parties That May Petition the Court to Determine Eligibility}

Another aspect of Kendra's Law, compared to some danger-or-gravedisability statutes, is that parents or siblings of the severely mentally ill individual are among those who may bring a petition seeking treatment for the individual. ${ }^{160}$ Under Kendra's law, eight classes of persons may file a petition

158 See TORREY, SURVIVING SCHIZOPHRENIA, supra note 12, at 205-06 ("In 1991 Dr. Richard Wyatt reanalyzed twenty-two studies on the course of schizophrenia and concluded that 'early intervention with neuroleptics in first-break schizophrenic patients increases the likelihood of an improved long-term course.' . . . The implication of these studies is that the failure by mental illness professionals to treat individuals with schizophrenia with antipsychotic medications as early in the course of their illness as possible may produce a worse outcome."); see also WEGKAMP, supra note 116, at 78, 252 (describing a family's struggle to obtain treatment for their college-age son diagnosed with schizophrenia after an initial psychotic episode). But $c f$. TORREY, SURVIVING SCHIZOPHRENIA, supra note 12, at 102-03 ("In general, the younger the age at which schizophrenia develops, the poorer the outcome. A person who is first diagnosed with schizophrenia at age fifteen is likely to have a poorer outcome than a person with the onset at age twenty-five.")

159 This leads one to wonder how preventive Kendra's Law really is in effect.

160 See Kendra's Law, N.Y. MENTAL HYG. Law § 9.60(d) (McKinney 2006). But see ALA. CODE $\S 22-52-1.2$ (LexisNexis 2006) (permitting any person to file a petition seeking the involuntary commitment of another person provided, among other criteria, that the petitioner "has reason to believe the respondent is mentally ill" and "that the beliefs of the petitioner are based on specific behavior, acts, attempts, or threats" specified in detail); ARK. CODE ANN. $§ 20$ 47-207 (2001 \& Supp. 2005) (requiring, however, that the petitioner state whether the person is believed to be a danger to himself or herself).

Yet, seeking a PVOT order is not the only route by which a family member may petition the court for involuntary treatment of a severely mentally ill individual in both New York and California. Under the danger-or-grave-disability statutes, such petitions are permitted so long as they are accompanied by a certified physician's statement that the civil commitment criteria are met. N.Y. MENTAL HYG. LAW $\S 9.27$ (b), (d) (stating that an application for involuntary treatment may be filed by "any person with whom the person alleged to be mentally ill resides[,] . . . the father or mother, husband or wife, brother or sister, or the child of any such person or the nearest available relative[,] ..." and several other professionals who may have knowledge of the alleged mental illness); Lanterman-Petris-Short Act, CAL. WELF. \& INST. CODE $\S 5201$ (West 1998) ("Any individual may apply to the person or agency designated by the county for a petition alleging that there is in the county a person who is, as a result of mental disorder a danger to others, or to himself, or is gravely disabled, and requesting that an evaluation of the person's condition be made."). See infra notes 179-80 and accompanying text (dis- 
requesting that an individual receive PVOT.

First, a person who is eighteen years or older "with whom the subject of the petition resides" may file a petition. ${ }^{161}$ On the one hand this sounds broad, but because the petitioner must be an adult who also lives with the individual it is far narrower than one might initially imagine. Though the issue has not as yet come before the New York courts, the statute would likely be interpreted to exclude those, for example, living in the same apartment complex building but in different apartments. Likewise, it would likely exclude neighbors who live in adjacent homes from filing a petition on someone they suspect to be suffering from a severe mental illness, no matter how genuine the petition. Nonetheless, the emphasis on having a residence, in general, may not encompass a fair amount of severely mentally ill persons and therefore may not make the most sense when aiming to protect this class of persons. After all, a sizable proportion of severely mentally ill persons have no residence. Many, such as Robert, ${ }^{162}$ are homeless or are incarcerated in some capacity.

Second, "[a] parent, spouse, sibling eighteen years of age or older, or child eighteen years of age or older" may file a petition seeking treatment for a mentally ill relative. ${ }^{163}$ Nieces, nephews, uncles, aunts, grandparents, grandchildren, and cousins are not on the list, and will not have authority to bring a petition, unless they are over eighteen and reside with the subject of the petition. While it seems the policy of this PVOT statute is to target those emotionally closest to the severely mentally ill individual, strict familial lines may be a weakness of the statute. ${ }^{164}$ For example, it leaves open the question of whether step-parents and half-siblings would equally qualify. Additionally, the general familial-emotional-attachment policy of the statute is inherently rebutted by the fact that most severely mentally ill persons have few emotional attachments. Some may be estranged from family members or have moved across the country and broken ties. In such a situation, a more pragmatic statutory provision of one who may bring this petition makes better sense. For example, an apartment neighbor or landlord who believes the individual may be in need of treatment because of specific reports or evidence they might have obtained. Hence, other states may wish to implement broader classes of persons who may bring a petition for PVOT based on these potential shortcomings of Kendra's Law.

The third through eighth groups of persons who may bring a petition to

cussing further the Lanterman-Petris-Short Act and identifying those who may file a petition under Laura's Law in California).

161 N.Y. MENTAL HYG. LAW $\$ 9.60(\mathrm{e})(1)(\mathrm{i})$. It is highly unlikely that a roommate of short duration (such as college dorm residents) would qualify because of the requirement that the illness must have manifested itself at least twice within the past three or four years in either hospitalization or forced medication during incarceration.

162 See supra Part IV.

163 N.Y. MENTAL HYG. LAW $\S 9.60(\mathrm{e})(1)(\mathrm{ii})$.

164 Cf. Moore v. City of East Cleveland, 431 U.S. 494, 495-96, 503-04, 506 (1977) (striking down a city housing ordinance that excluded grandparents from the definition of family). "Especially in times of adversity ... the broader family has tended to come together for mutual sustenance and to maintain or rebuild a secure home life." Id. at 505. 
the court include medical professionals and police officers who have past experience with the particular individual sought to be treated. ${ }^{165}$ While these final categories of persons authorized to file a petition make a great deal sense, one would also query as to whether any person over eighteen-for example, a teacher, landlord, neighbor, or supermarket owner-who has "past experience with the particular individual sought to be treated" might also be permitted to file a petition. Should not the policy of the statute be to protect severely mentally ill persons over drawing explicit ties to residence partners, family members, or mental health or law enforcement professionals? Certainly, if such broad petitions were permitted to be filed they would need to continue to be screened for abuse. ${ }^{166}$

Though several classes of persons are statutorily authorized under Kendra's Law to file a petition on behalf of a severely mentally ill individual, the petition must also include the sworn statement of a physician, who has examined the person within ten days of the filing of the petition, which attests to the need for PVOT. 167 Additionally, a person who files a "false petition" by "making a false statement or providing false information or false testimony in a petition or hearing" is subject to criminal prosecution. ${ }^{168}$ Jurisdictions that wish to adopt Kendra's Law or a PVOT statute similar to it should consider the policy positions it represents before enacting the identical language into law.

\section{B. Laura's Law of California}

Laura's Law uses virtually identical language to Kendra's Law, however, since it was modeled two years after Kendra's Law took effect, Laura's Law is modified in areas where Kendra's Law was vague or unclear. ${ }^{169}$ For example, Laura's Law states at the front-end of the statute that a court must find each of the criteria by the "clear and convincing evidence" standard. ${ }^{170}$ In New York, while the same standard is applied under Kendra's Law, it is buried within the detailed language of the statute. ${ }^{171}$ Hence, some of the revisions of Laura's Law are more technical than substantive, though initially they may appear otherwise.

165 N.Y. MENTAL HYG. LAW $\S 9.60(e)(1)($ iii)-(viii).

166 Id. $\$ 9.60(\mathrm{e})(3)(\mathrm{i}),(\mathrm{p})$.

167 Id. $\S 9.60(\mathrm{e})(3)(\mathrm{i})$.

168 Id. $\$ 9.60(\mathrm{p})$.

169 Laura's Law, CAL. WeLF. \& INST. CODE $\S \S 5345-5349.5$ (West Supp. 2007). The bill was signed into law in 2002, and it became effective in 2003. Assisted Outpatient Treatment Demonstration Project Act of 2002 ("Laura's Law"), ch. 1017, 2002 Cal. Legis. Serv. 5046 (West); Cal. Treatment Advoc. Coalition, Laura's Law Implementation, http://www.psychlaws.org/StateActivity/California.htm (last visited Mar. 17, 2007). The law currently has a sunset provision set for 2013. CAL. WELF. \& INST. CODE $§ 5349.5(a)$.

170 CAL. WELF. \& INST. CODE $\S 5346(a)$.

$171 C f$. N.Y. MENTAL HYG. LAW $\S 9.60(\mathrm{j})(2)$. 


\section{Eligibility Requirements}

Laura's Law sets forth nine criteria that must each be met by clear and convincing evidence for an individual to receive PVOT. ${ }^{172}$ Seven out of those nine criteria are substantively identical to Kendra's seven criteria. Only two new eligibility criteria are presented. Compared to Kendra's Law, Laura's Law's two additional criteria may raise the threshold for treatment eligibility slightly.

First, Laura's Law requires that "the person's condition is substantially deteriorating." 173 This "substantial deterioration" criterion does not appear radically different from the narrower requirement of Kendra's Law (that Laura's Law also retains) that treatment be necessary "to prevent a relapse or deterioration that would be likely to result in grave disability or serious harm." ${ }^{174}$ Nonetheless, the criterion does seem to reflect a policy that deterioration of a mental illness is not only captured through evidence of grave disability or serious harm to self-or-others. Yet, if the legislature thought this was the case, why would they retain the other provision that requires this specific finding of grave disability or harm? Hence, Laura's Law's requirement of a general finding that the individual's condition is deteriorating while retaining the narrower finding that deterioration is likely to result in harm seems to be a revision without much effect. It would seem that other jurisdictions looking to model a PVOT statute after Laura's Law should consider the policy implications of each before choosing whether to retain or omit the additional factor. A movement away from the danger-or-grave-disability statutes would be best reflected by retaining the broad criterion in Laura's Law and omitting the narrower criterion that requires a finding of likelihood of serious harm.

Second, Laura's Law requires that "participation in the assisted outpatient treatment program ... be the least restrictive placement necessary to ensure the person's recovery and stability." 175 While the least restrictive treatment doctrine is not constitutionally required, the doctrine has some constitutional status in civil commitment cases and requires that the recommended treatment be the least invasive treatment available before a physician orders it. ${ }^{176}$ Nonetheless,

172 CAL. WELF. \& INST. CODE $\S 5346(a)(1)-(9)$.

173 Id. $\S 5346(\mathrm{a})(6)$.

174 Id. $\S 5346(\mathrm{a})(8)$ (emphasis added); N.Y. MENTAL HYG. LAW $\S 9.60(\mathrm{c})(6)$.

175 CAL. WELF. \& INST. CoDE $\$$ 5346(a)(7) (emphasis added).

176 It has not yet been resolved as to whether the least restrictive alternative doctrine has constitutional status with respect to civil commitment proceedings. See Youngberg v. Romeo, 457 U.S. 307, 321. For support that the doctrine may have some constitutional status, see Lake v. Cameron, 364 F.2d 657, 660-61 (D.C. Cir. 1996), cert. denied, 382 U.S. 863 (1965) (remanding for a determination of other available courses of treatment outside of inpatient treatment). "The alternative course of treatment or care should be fashioned as the interests of the person and of the public require in the particular case.... [it is] the court's duty to explore alternatives in such a case." Id. at 660. See generally RALPH REISNER, CHRISTOPHER SLOBOGIN \& ARTI RAI, LAW AND The MENTAL HEALTH SySTEM: Civil AND CRIMINAL ASPECTS 750-51 (4th ed. 2004). 
Kendra's Law also provides that the least restrictive treatment be used, however, it is detailed in a different section of the statute. ${ }^{177}$ Even so, Laura's Law's codification of the least restrictive treatment doctrine up front in the statute may bring more clarity to courts and laypersons as to how the statute is to be applied.

More theoretically, one has to wonder what the parameters of a doctrine such as the "least restrictive treatment" are in an era of psychiatric treatment that is more often administered in physically non-restrictive environments through taking medication. It will be interesting to see in the years aheadwith a continued shift toward more outpatient treatment and medication-how the courts will begin to interpret this doctrine in light of psychopharmaceutical advances. $^{178}$

\section{Third Parties That May Petition the Court to Determine Eligibility}

Aside from Laura's Law's slight deviations from Kendra's Law with respect to the treatment eligibility criteria, one of the biggest differences between the two statutes concerns those who are permitted to file a petition seeking medical treatment on behalf of a severely mentally ill individual. Laura's Law is more conservative than Kendra's Law and only allows the county mental health director to file the petition. ${ }^{179}$ Similar to Kendra's Law, however, it permits nuclear family members, a person with whom the individual resides, or mental health experts and police officers with whom the individual has established contact, to request that the mental health director file the petition. ${ }^{180}$ Hence the language of the statute covers all of the same groups that Kendra's Law covers. It is prefaced, however, by the statement that "a request may be made only by any of the following persons to the county mental health department for the filing of a petition to obtain an order authorizing assisted outpatient treatment." 181

One critique of this provision is that it makes a bureaucratic governmental system the threshold check, which could stymie the PVOT application process. Further, it is not established how the department will evaluate the requests for

177 N.Y. MENTAL HYG. LAW $\S 9.60(j)(2)$.

178 For example, will least restrictive mean the least side-effects? If so, who determines which side effects are more restrictive than others? See also REISNER, SLOBOGIN \& RAI, supra note 176, at 751-52 (citing Browning Hoffman \& Lawrence Foust, Least Restrictive Treatment of the Mentally Ill: A Doctrine in Search of Its Senses, 14 SAN DIEGO L. REV. 1100, 1139-43 (1977)).

179 CAL. WeLF. \& INST. CoDE $§ 5346$ (b). Under California's Lanterman-Petris-Short Act, which is the state's danger-or-grave-disability statute, any person may file a petition in good faith on behalf of another he or she believes to be severely mentally ill and in need of involuntary outpatient treatment. CAL. WeLF. \& INST. CODE $\$ \S 5201,5203,5300$ (a) (West 1998). See supra note 160 for the precise language of the statute.

180 CAL. WeLf. \& INST. CODE $\S 5346(\mathrm{~b})(2)$.

181 Id. 
filing the petitions. The counterargument, however, is that limiting the class of persons who may file a petition to the county mental health department alleviates the risk of personal bias and will better ensure that civil liberties are upheld and fraudulent petitions are not filed. Further, it is possible from a psychological perspective that reserving the power to file a petition to the county mental health department will be less fraught with emotion than having someone with whom the individual has built emotional trust file the petition. ${ }^{182}$ On the other hand, having those who know the individual best file the petition for outpatient treatment might better persuade the individual to comply with treatment. If the severely mentally ill individual sees that those who care for him or her believe psychiatric treatment is needed, it is possible the severely mentally ill individual might be more likely to comply with treatment.

\section{JURISDICTIONS THAT HAVE MODELED LEGISLATION AFTER KENDRA AND LAURA}

Laura's Law and Kendra's Law each provide slightly different policy positions that other jurisdictions may follow or learn from. Florida, Michigan, and Ontario, Canada, have enacted PVOT statutes similar to Laura's Law and Kendra's Law. New Mexico, Tennessee, and Ohio currently have PVOT bills pending. New Jersey's legislature has also recently proposed a PVOT bill, but in light of the strength of the opposition, it does not appear likely that PVOT will be adopted in New Jersey at this time.

\section{A. Enacted PVOT Statutes}

Florida's PVOT law became effective in $2005 .{ }^{183}$ It is virtually identical to Laura's Law in having incorporated eight of the nine criteria set forth for treatment eligibility of a mentally ill individual. ${ }^{184}$ Florida's PVOT statute, however, further limits the number of persons who may file a petition for treatment in comparison to both Kendra's Law and Laura's Law. The only persons who may file a petition are " $[t]$ he administrator of a receiving facility; or ...

182 See generally Perlin, supra note 3, at 206 (analyzing Kendra's Law from a therapeutic jurisprudence perspective).

183 FLA. Stat. ANN. § 394.4655(1)(a)-(i) (West Supp. 2007); Act of June 30, 2004, ch. 385,2004 Fla. Laws 2964 . The law was initiated after a plumber who was severely mentally ill wounded two deputies in 1998 and shot another to death. Fritz, supra note 8, at A12.

184 See Fla. STAT. ANN. § 394.4655(1)(a)-(i) (West Supp. 2007); compare with CAL. WELF. \& INST. CODE § 5346(a)(1)-(9). Florida's PVOT statute omits the criterion in Laura's Law that requires a general finding that the "person's condition is substantially deteriorating." Compare FLA. STAT. ANN. § 394.4655(1) with CAL. Welf. \& INST. CODE § 5346(a)(6). Therefore, the Florida statute retains nine criteria total, having split one criterion of Laura's Law into two parts. Compare Fla. STAT. ANN. § 394.4655(1)(d), (e) with CAL. WeLF. \& INST. CodE § 5346(a)(4). 
[t]he administrator of a treatment facility." statute expressly permitting family members or other individuals who may have intimate knowledge of the individual's condition to request that an administrator of a treatment facility file a petition. ${ }^{186}$ Leaving this language out may deter family and community involvement in ensuring treatment is provided for someone believed to be severely mentally ill. ${ }^{187}$ Nonetheless, the statute does not expressly say that family members or community members may not make such requests.

Michigan's PVOT statute, titled Kevin's Law, ${ }^{188}$ also became effective in 2005 . $^{189}$ Kevin's Law, however, was integrated within the language of existing Michigan mental health statutes. For instance, Kevin's Law expands the definition of "person requiring treatment" under the Michigan Mental Health Code, rather than drafting a separate subsection within the code (as other states have done). ${ }^{190}$ Kevin's Law, nonetheless, seems to have incorporated elements of both Kendra's Law and Laura's Law but has also boiled them down into five primary criteria for eligibility. ${ }^{191}$ Reducing the criteria for treatment eligibility may lighten the state's burden slightly. Nonetheless, Kevin's law has retained the most difficult eligibility criteria. ${ }^{192}$ Additionally, Kevin's Law permits any person over the age of eighteen to bring a petition requesting that an individual

185 Fla. Stat. ANN. § 394.4655(3)(a)(1)-(2).

186 See Kendra's Law, N.Y. MENTAL HYG. LAW § 9.60(e)(i)-(ii) (McKinney 2006); CAL. WELF. \& INST. CODE § 5346(b)(2)(A)-(B).

187 See supra notes $181-82$ and accompanying text.

188 Kevin's Law was named after Kevin Heisinger, a twenty-four-year-old college student who was beaten to death in 2000 by a Vietnam veteran with a history of schizophrenia. Fritz, supra note 8, at A12.

189 See The Beginning of Hope: Kevin's Law to Aid the Mentally Ill, TrEATMENT AdVOC. CTR., Mar. 30, 2005, at http://www.psychlaws.org/PressRoom/rls-kevinslawlaunched.htm.

190 Kevin's Law, Mich. CoMP. LAWS ANN. § 330.1401(401)(1)(d)(West Supp. 2007); see also Governor Granholm Signs Kevin's Law, Creates New Treatment Options for Mentally Ill, MICHIGAN.GOV, Dec. 29, 2004, at http://www.michigan.gov/gov/0,1607,7-168-23442_21974107105--M_2004_12,00.html.

191 First, the presence of a mental illness must be established. Second, a lack of insight that makes the individual unlikely to participate in voluntary treatment must be established. Third, the individual must currently be noncompliant with treatment. Fourth, forced treatment will prevent a relapse or deterioration. And, fifth, that noncompliance has been a factor in the individual's placement in a psychiatric hospital, prison, or jail at least twice within the last four years. See Mich. CoMP. LAWS ANN. § 330.1401(401)(d).

192 MICH. COMP. LAWS ANN. § 330.1401(401)(1)(d) (requiring, in particular, that "noncompliance with treatment has been a factor in the individual's placement in a psychiatric hospital, prison, or jail at least 2 times within the last 48 months or whose noncompliance with treatment has been a factor in the individual's committing 1 or more acts, attempts, or threats of serious violent behavior within the last $\mathbf{4 8}$ months."). Note that both Kendra's Law and Laura's law restrict the first prong of this test to three rather than four years. See Kendra's Law, N.Y. MENTAL HYG. LAW § 9.60(c)(4)(i)-(ii) (McKinney 2006); Laura's Law, CAL. WELF. \& INST. CODE $\S 5346(a)(4)$ (West Supp. 2007). 
receive PVOT. ${ }^{193}$ This policy permits a teacher or landlord to file a petition, and may therefore facilitate PVOT in the most preventive fashion, as the petitioner need not wait until a police officer or mental health professional encounters the severely mentally ill individual. Further, under Kevin's Law, like the other PVOT statutes, the petition must be accompanied by a clinical certificate by a physician or an affidavit explaining why none was able to be secured. ${ }^{194}$

Finally, in 2000, the province of Ontario, Canada, enacted a PVOT statute called Brian's Law. ${ }^{195}$ Brian's Law eliminates the prior Canadian immanency requirement of dangerousness as the threshold for treatment, and now permits evidence of deteriorating and chronic condition through evidence such as prior hospitalizations. ${ }^{196}$ Similar to the American PVOT statutes, Brian's Law allows family members and mental health professionals to file petitions on behalf of a mentally ill individual. ${ }^{197}$

\section{B. Other Jurisdictions Transitioning to Add PVOT}

New Mexico's House of Representatives passed a bill in 2007 that may

193 Mich. Comp. LaWs ANN. § 330.1434(434)(1) (West 1999).

194 Mich. COMP. LAWS ANN. § 330.1401(434)(3).

195 E.g., Cornwell \& Deeney, supra note 3, at 230-31. Brian was a well known sportscaster who was shot to death by a man diagnosed with paranoid schizophrenia who refused treatment despite the advice of his psychiatrists. E.g., David A. Harris, Brian's Law Broadens Criteria For Treating the Mentally Ill, BURLINGTON PosT, Oct. 17, 2001, available at $\mathrm{http} / / / \mathrm{www}$. lawyers.ca/dharris/articles/brianslaw.htm (last visited Mar. 5, 2006).

196 E.g., Gov'T OF ONTARIO, CANADA, Ministry OF HEALTH AND LONG-TERM CARE, MENTAL HEALTH: BRIAN's LAW 2 (2000), available at http://www.health.gov.on.ca/english/public/pub/mental/brianslaw.html (last visited Mar. 6, 2006).

${ }^{197}$ Id. "As in the United States, this legislative initiative has proven quite controversial in Canada. Although critics have offered many of the same objections directed at ... [PVOT], they have the added concern that Canadian mental health consumers lack the same measure of constitutional protection enjoyed by their American counterparts." Cornwell \& Deeney, supra note 11 , at 231 .

Additionally, Illinois recently passed a civil commitment statute that is similar to PVOT in some key respects. Illinois Gov. Signs Legislation to Improve State's MI Treatment Law, MENTAL HeAlTH WeEKLY, Sept. 24, 2007, at 3. The term "person subject to involuntary admission" in the existing Illinois civil commitment statute has been expanded to include

a person with mental illness who, because of the nature of his or her illness, is unable to understand his or her need for treatment and who, if not treated, is reasonably expected to suffer or continue to suffer mental deterioration or emotional deterioration, or both, to the point that the person is reasonably expected to engage in dangerous conduct.

S.B. 234, 95th Gen. Assem., Reg. Sess. (Ill. 2007) (emphasis added). While the statute still focuses on potential dangerousness as a trigger for treatment, the definition of dangerousness is now much broader and therefore is very similar to other PVOT statutes. See id. (defining dangerousness as "threatening behavior or conduct that places another individual in reasonable expectation of being harmed ....") (emphasis added). 
create a PVOT statute in New Mexico in the near future. ${ }^{198}$ The proposed bill includes elements of both Kendra's Law and Laura's Law. ${ }^{199}$.The earlier version even proposed to take Kendra's name for the bill, ${ }^{200}$ though the current bill is titled "mandated community treatment." 201 There are seven eligibility criteria for PVOT under the bill, as well as a preamble that requires the proposed treatment be the least restrictive. All but one of the criteria, the first criterion, appear similar to both Kendra's Law and Laura's Law.

The first criterion of the New Mexico bill is unique in that it requires that the mentally ill individual lack capacity. Capacity is defined in the bill as "a person's ability to understand and appreciate the nature and consequences of proposed mental health treatment, including significant benefits and risks and alternatives to the proposed mental health treatment, and to make and communicate an informed mental health treatment decision." "202 While Kendra's Law and Laura's Law fail to expressly require a "capacity" criterion, it is arguably implicit (as "capacity" is defined by the New Mexico bill) in those criteria that require the individual be unlikely to voluntarily participate in outpatient treatment or unlikely to survive safely in the community without supervision. By comparison, the proposed New Mexico bill retains the "unlikely to voluntarily participate" criterion but omits the "unlikely to survive safely without supervision" criterion. ${ }^{203}$ While the proposed definition of "capacity" in the bill seems

198 H.B. 609, 48th Leg., 1st Sess. (N.M. 2007) (passed Feb. 24, 2007). While forty-two states have some form of AOT laws, New Mexico is one of the eight states that currently has no form of AOT. Hence adoption of PVOT would be a radical shift for the New Mexico mental health system as no form of outpatient treatment is otherwise available. See also Treatment Advoc. Ctr., Top Policy Makers Support AOT for New Mexico, http://psychlaws.blogspot.com/2006/02/top-policymakers-support-aot-for-new.html (last visited Mar. 31, 2007). The event which spurred citizens and legislators to draft a new bill to adopt PVOT occurred in August 2005. See H.B. 174, 47th Leg., 2d Sess. (N.M. 2006). John Hyde, forty-eight-years-old and diagnosed with schizophrenia and bipolar disorder, shot and killed five people in Albuquerque, including two police officers who were dispatched to the scene. See id. According to his family, for at least five months prior to the shooting, John had been off his medication. See id. Even local church officials had previously called the police to have John hospitalized, but he was continually released after short periods of time, in one case, just four hours. See id. See also Help Mentally Ill Out of Danger Zone AlBUQUERQUE J., Jan. 1, 2006, at B2, segment available at http://www.psychlaws.org/StateActivity/NewMexico.htm. Representative Gutierrez commented that "[e]xisting New Mexico law essentially forces people who lack insight into their illness to hit rock bottom before they can be helped ... [and that f]orced deterioration is cruel and inhumane." Id.

199 H.B. 609, 48th Leg., \$4, 1st Sess. (N.M. 2007) (passed Feb. 24, 2007).

200 H.B. 174, 47th Leg., 2d Sess. (N.M. 2006); see also Cal. Network of Mental Health Clients, AB 2357-Why Oppose It, www.californiaclients.org/policy/ab2357.cfm [hereinafter Cal. Network of Mental Health Clients, AB 2357-Why Oppose It] (last visited Apr. 1, 2007) (stating that this version of New Mexico bill died on the floor of the legislature).

201 H.B. 174, 47th Leg., 2d Sess. (N.M. 2006); H.B. 609, 48th Leg., 1st Sess. (N.M. 2007).

202 H.B. 609, 48th Leg., § 2B, 1st Sess. (N.M. 2007) (defining capacity).

203 Laura's Law, CAL. WELF. \& INST. CODE § 5346(a)(3) (West Supp. 2007); Kendra's 
narrowly tailored to target severely mentally ill individuals, it may have the effect of creating a higher standard than the legislature intended (or that PVOT statutes in general are aiming toward). A more appropriate term to use for this criterion might be "insight" because capacity is generally a weightier legal term, and as generally defined it could effectively prohibit the use of PVOT for a large portion of severely mentally ill individuals. ${ }^{204}$

Additionally, the New Mexico bill, similar to Kendra's Law, permits family members, among a long list of eleven other persons, to file a petition for PVOT. ${ }^{205}$ The bill further proposes that "the director of a public or charitable organization ... where the respondent resides or provides mental health services" also be permitted to file the petition. ${ }^{206}$ This expands the scope of persons permitted to file a petition for PVOT compared to Kendra's Law.

Tennessee's General Assembly introduced a PVOT bill in $2007 .{ }^{207}$ The bill is virtually identical to Kendra's Law. ${ }^{208}$ It includes the same PVOT eligibility criteria as well as the classes of persons permitted to file a petition to seek a PVOT order on behalf of a third party. ${ }^{209}$ Similarly, Ohio introduced a PVOT bill in 2007 that is nearly identical to Kendra's Law. ${ }^{210}$ Though the proposed bill alters some terms, the core substance of the bill is the same. ${ }^{211}$

New Jersey proposed a PVOT bill in 2006 named Gregory's Law. ${ }^{212}$ The bill that was passed by the senate six months later, however, omitted the originally proposed PVOT language. ${ }^{213}$ Thus, the bill currently passed by the senate and awaiting confirmation by the assembly is a general AOT statute rather than a PVOT statute. New Jersey, like New Mexico, currently has no form of AOT whatsoever, and therefore the need for AOT, in any form, is great. ${ }^{214}$ The original bill introduced in the senate, however, was modeled after Kendra's

Law, N.Y. MENTAL HYG. LAW $§ 9.60(c)(3)$ (McKinney 2006).

204 See supra Part III.C.

205 H.B. 609, 48th Leg., §5, 1st Sess. (N.M. 2007) (passed Feb. 24, 2007).

${ }^{206}$ H.B. 609, 48th Leg., $\$ 5(A)(6)$, 1 st Sess. (N.M. 2007) (passed Feb. 24, 2007).

207 H.B. 1883, 105th Gen. Assem. (Tenn. 2007) (introduced Feb. 8, 2007).

208 See id.

209 Id. $\S(\mathrm{c})(1)-(7),(\mathrm{e})$.

210 H.B. 299, 127th Gen. Assem., Reg., Sess. (Ohio 2007) (introduced Aug. 21, 2007).

211 See id. For example, instead of listing all the various medical professionals who may file a petition under that section of the statute, see N.Y. MENTAL HYG. LAW § 9.60(e)(i)-(viii) (McKinney 2006), the proposed Ohio bill defines "mental health professional" in much the same manner in the definitions section of the statute. H.B. 299, 127 th Gen. Assem., Reg., Sess. (Ohio 2007).

212 S.B. 1093, $\S 2 \mathrm{~m}(2), 212$ th Leg. (N.J. 2006) (introduced Jan. 26, 2006). The New Jersey Assembly also introduced a nearly identical bill during the same month that never made it out of committee. A.B. 367, 212th Leg. (N.J. 2006) (introduced Jan. 10, 2006).

213 S.B. 1093, § 2m, 212th Leg. (N.J. 2006) (substituted June 15, 2006) (passed June 22, 2006 and sent to the Assembly).

${ }^{214}$ See Press Release, Treatment Advoc. Ctr., Governor's Task Force on Mental Health Recommends AOT for New Jersey (Mar. 31, 2005), available at http://www.psychlaws.org/PressRoom/rls-NJTaskForce.htm. 
Law. ${ }^{215}$ It provided five criteria for treatment eligibility similar to both Kendra's Law and Laura's Law. ${ }^{216}$ Additionally, Gregory's Law would have permitted any individual to petition the court for a PVOT order on behalf of a severely mentally individual by submitting two clinical certificates, one from a psychiatrist, to the court. ${ }^{217}$ While it appears that Gregory's Law did not survive the senate chambers as originally proposed, Gregory's Law shows yet another jurisdiction whose legislature has considered adopting a PVOT statute, though in this instance, and at the current time, it appears New Jersey has decided against its adoption.

\section{CONSTITUTIONAL ANALYSIS OF PVOT STATUTES}

While the previous sections have highlighted a variety of policy positions at work in PVOT statutes, assessing the constitutionality of PVOT statutes is critical in order to better anticipate the constitutional strength of PVOT statutes in years ahead. The constitutional status of PVOT statutes has not reached the United States Supreme Court. ${ }^{218}$ Nonetheless, the highest court in New York upheld the constitutionality of Kendra's Law in In re K.L. ${ }^{219}$ In In re K.L. the court held that Kendra's Law was narrowly tailored to achieve state goals, and that New York had a compelling interest under state law ${ }^{220}$ to order PVOT under both its police and parens patriae powers. ${ }^{221}$ The court thus upheld

215 See S.B. 1093, 212th Leg. (N.J. 2006) (introduced Jan. 26, 2006). Gregory's Law was named after eleven-year-old Gregory Katsnelson who was stabbed to death in October 2002 while riding his bicycle near his home by twenty-six-year-old Ronald Pituch who had just beaten his own mother to death with a barbell because she had refused to buy him cigarettes. $I d$. Pituch had a lengthy history of treatment for schizophrenia but denied that he was mentally ill and refused to take medication. Id. Members of Pituch's family had attempted to get him forced treatment but were unable to have him civilly committed without his consent and due to the high evidentiary threshold in the danger statutes. See id.

216 S.B. 1093, 212th Leg. (N.J. 2006) (introduced Jan. 26, 2006).

217 S.B. 1093, § 2m, 212th Leg. (N.J. 2006) (substituted June 15, 2006) (passed June 22, 2006 and sent to the Assembly); see also A.B. 367, 212th Leg. (N.J. 2006) (introduced Jan. 10, 2006).

218 For arguments that PVOT is constitutional see generally Cornwell \& Deeney, supra note 3, at 219-25, and Watnik, infra note 222, at 1208. For arguments that PVOT is unconstitutional see generally Gutterman, supra note 10 , at 2403, 2439-44, Campbell, infra note 238, at $175,185-99$, and O'Connor, supra note 3, at 339-58. Each of these law review articles (the latter three were comments or notes) was published between 2000 and 2003.

${ }^{219}$ In re K.L., 806 N.E.2d 480, 486, 487 (N.Y. 2004).

220 New York applies a higher level of scrutiny-requiring a "compelling" interest-than that which would be applied by the federal courts. See infra notes 230-33 and accompanying text.

221 There are two sources of power from which states may enact civil commitment statutes. See U.S. ConST. amend. X. First is each state's police power. See, e.g., Hortas, supra note 11 , at 164 . This is the power of each state to protect the health, safety, and welfare of its citizens. See, e.g., id. Second is each state's parens patriae power. E.g., id. Parens patriae means "parent of the country." E.g., Gutterman, supra note 10, at 2428 (quoting BARBARA A. 


\section{Kendra's Law on substantive and procedural ${ }^{222}$ due process grounds. ${ }^{223}$}

Weiner \& Robert M. Wettstein, Legal IsSues in Mental Health Care 47 (1993)). This power allows the state to step in as a paternal figure to care for an individual who typically lacks a certain level of capacity or competency. REISNER, SLOBOGIN \& RAI, supra note 176, at 712-16. Generally, most AOT statutes are a simultaneous exercise of both police and parens patriae powers.

PVOT statutes, like the danger-or-grave-disability statutes, are an exercise of both police and parens patriae powers. PVOT statutes seek to prevent harm and danger to the public or the individual even though based on more probabilistic tendencies towards violence than the danger statutes. Hence, PVOT may be a more vivid exercise of the parens patriae powers in comparison to the danger statutes because of the focus on effectively treating and rehabilitating the individual far sooner than the actual occurrence or "immanency" of harm.

${ }^{222}$ In re K.L., 806 N.E.2d 480, 487 (N.Y. 2004). Ultimately, procedural due process is determined by judicial balancing based on the particular process given under any PVOT or AOT statute. Therefore the precise outcome of any particular PVOT statute on this issue will always depend on the particular procedure the statute provides for.

In the instant case, K.L. argued that Kendra's Law violated procedural due process by failing to provide notice and a hearing prior to his temporary removal to a hospital for failure to comply with the PVOT order. See In re K.L., 806 N.E.2d at 486 . The court rejected this argument, again focusing on the state's "quite strong" interest in removing from the streets persons who as a result of noncompliance are at risk of relapse or deterioration likely to result in harm to themselves or others. $I d$. at 487 . The court noted that a physician is still required to re-examine the patient to determine whether hospitalization is necessary upon failure to comply with PVOT. Id. The court also stated that a pre-removal judicial hearing during the middle of court-ordered PVOT would significantly reduce the speed with which the patient can be evaluated and potentially begin to receive needed treatment if a physician has reason to believe it is needed. $I d$.

While there is no strict formula for determining whether procedural due process has been met by a particular PVOT statute, the United States Supreme Court in Mathews v. Eldridge articulated a balancing test, which requires that procedural protections reflect the level of infringement on the claimant's interests. Mathews v. Eldridge, 424 U.S. 319, 334-35(1976). See also Ilissa L. Watnik, Comment, A Constitutional Analysis of Kendra's Law: New York's Solution for Treatment of the Chronically Mentally Ill, 149 U. PA. L. REV. 1181, 1209 (2001) (discussing the application of the Mathews balancing test to procedural claims against PVOT statutes). "Consistent with the sliding scale approach of the Matthews [sic] balancing test, all states have granted fewer procedural protections to outpatients than to inpatients, due to the lower restriction on liberty involved in outpatient treatment." Id. at 1208. Hence, procedural processes for PVOT and AOT might not need to be as stringent as those for hospitalization, since more freedoms are taken when someone is physically confined. Nonetheless, some would argue that forcibly medicating someone-that is altering their mental state - even if in an outpatient setting, is more violative of liberty interests than being physically confined. SAKS, REFUSING CARE, supra note 18, at 87 . Yet medication has become one of the best tools for treating the severely mentally ill. Therefore, analyzing procedural due process claims under PVOT and AOT statutes in terms of literal physical barriers or liberty interests may no longer be the best way to evaluate whether due process has been satisfied.

Nonetheless, legal academics have identified several critical constitutional minimums for civil commitment procedures: 1) legal representation at all stages of the hearing, 2) testimony from the examining physician at the hearing stating the rationale for the recommended treatment, 3) availability of the physician and other adverse witnesses for cross-examination, and 4) notice of the hearing served to the subject of the petition. See Watnik, supra note 222, at 1209,1227 (discussing the procedural due process concerns under Kendra's Law but concluding it is likely a constitutional exercise of state power). These procedural prerequisites are ad- 
In In re K.L., K.L. was diagnosed with schizoaffective disorder ${ }^{224}$ and also had a history of noncompliance with treatment and psychiatric hospitalization. $^{225}$ K.L. raised several arguments regarding the constitutionality of Kendra's Law, under which he had been involuntarily court-ordered to receive psychiatric treatment, including attending case management meetings, submitting to regular blood testing, attending individual therapy sessions, and selfadministering the antipsychotic Zyprexa. ${ }^{226}$ In holding for the state and permitting PVOT under Kendra's Law to be administered, ${ }^{227}$ the New York court em-

dressed by the current PVOT statutes. Protection of constitutional rights and liberties were clearly in mind when PVOT statutes were drafted. Kendra's Law, ch. 408, 1999 N.Y. Laws 2870, 2874-75 (codified at N.Y. MENTAL HYG. LAW $\S 9.60$ ) (describing the right to counsel and various levels of hearings); Assisted Outpatient Treatment Demonstration Project Act of 2002 ("Laura's Law"), ch. 1017, 2002 Cal. Legis. Serv. 5046 (West) (codified at CAL. WELF. \& INST. CODE $§ \S 5345-5349.1$ ) ("This bill would specify ... various rights of the person who is the subject of the petition, and hearing procedures."). See also Kendra's Law, N.Y. MENTAL HYG. LAW § 9.60(m), (n) (McKinney 2006) (specifying, for example, a maximum seventy-two-hourhold for a hospital psychiatric exam, if none other is able to be obtained). Ultimately, whether any particular state PVOT statute meets procedural constitutional standards will depend on the specific language of each state's PVOT statute.

${ }^{223}$ In re K.L., 806 N.E.2d 480, 486 (N.Y. 2004).

224 Schizoaffective disorder is a subtype of schizophrenia that includes significant symptoms of mood disturbances. See AM. PSYCHIATRIC Ass'N, DSM-IV-TR, supra note 47, at 159. K.L. had a diagnosis of Schizoaffective with bipolar type. In re K.L., 806 N.E.2d at 482.

225 In re K.L., 806 N.E.2d at 482.

226 Id.

227 Id. at 486. K.L. argued that Kendra's Law violated substantive due process because it lacked a determination of incapacity before permitting forced medication or treatment against the patient's will. Id. at 483-84. In Rivers v. Katz, 495 N.E.2d 337 (N.Y. 1986), the New York Court of Appeals held that where the state does not have a police power interest in forcing medication but merely a parens patriae power interest, mentally ill patients who are competent have a constitutional right to refuse medication. $I d$. at $343-44$. Therefore a finding of incapacity is required under New York law in situations in which only the parens patriae power is implicated to permit forced medication. Id. In Rivers, at issue was the forced medication of several severely mentally ill persons in an inpatient facility in which the court determined the police powers were no longer implicated. Id. at 339, 343-44. The court in In re K.L. rejected the incapacity argument by distinguishing the case from Rivers, stating that Kendra's Law "neither authorizes forcible medical treatment in the first instance nor permits it as a consequence of noncompliance ...." and emphasizing that both the police powers and parens patriae powers were implicated under Kendra's Law, thereby eliminating the application of Rivers. See In re K.L., 806 N.E.2d at 484-85. In particular, the court's statement that Kendra's Law does not require treatment by medication is slightly ambiguous. See id. at 484 . Certainly, a PVOT recipient may be an active part of developing the written treatment plan and ensuring it is the least restrictive treatment, however, it is not clear that there is a realistic alternative to forced medication if the court decides by clear and convincing evidence that such treatment is necessary and is the least restrictive. N.Y. MENTAL HYG. LAW § 9.60(i)(1)-(3), (j); see In re K.L., 806 N.E.2d at 484. Further, the N.Y. Report shows that medication adherence is an integral part to the success of Kendra's Law and effectively treating the severely mentally ill. See N.Y. REPORT ON KENDRA's LAW, infra note 247 , at 12 . Aside from this ambiguity regarding medication, the incapacity rule of Rivers was still not binding because the police powers are an integral part of PVOT. See In re K.L., 806 N.E.2d at 485. 
phasized that the "right of mentally ill persons to refuse treatment may have to yield to compelling state interests[,]"228 the findings must be made by clear and convincing evidence, and that the treatment proscribed must be the least restrictive alternative. ${ }^{229}$

With respect to the right to refuse psychiatric medication, the United States Supreme Court has identified the existence of a right to refuse medication, but only in inpatient hospitalization and incarceration contexts. ${ }^{230}$ Further, the Court has been consistent in refusing to define the right as fundamental, which would require the Court to apply strict scrutiny. ${ }^{231}$ With respect to mentally ill individuals who are hospitalized in an inpatient setting, the Court has held that mentally ill individuals have a liberty interest in avoiding the unwanted administration of antipsychotic drugs. ${ }^{232}$ The Court has left great leeway to the states for striking the constitutional balance between a patient's interest to refuse medication and state's interest in medicating a patient already in a controlled hospital setting. ${ }^{233}$

With respect to mentally ill individuals in the prison setting, the Court has applied two differing standards of review to two different groups of imprisoned individuals: 1) those held in jail awaiting or during trial and 2) those already convicted and sent to prison. In the former instance, the Court has applied midlevel scrutiny, ${ }^{234}$ holding that the state must make a "finding that might support a conclusion that administration of antipsychotic medication was necessary to accomplish an essential state policy ....,235 In the latter instance, concerning an inmate convicted of a crime, the court has held that the state's interest in medicating an inmate against his will must be merely reasonably related to a legitimate penal objective. ${ }^{236}$

The shifting standards of review the court has articulated with respect to the right to refuse medication thus far depend on the setting in which the medication is sought to be administered. Critically, the standard of review depends on the strength of the liberty interest in the particular setting in which medica-

${ }^{228}$ In re K.L., 806 N.E.2d at 485 (applying a state level of scrutiny).

229 Id. at 486 .

230 See Washington v. Harper, 494 U.S. 210, 222-23, 229 (1990) (prison); Mills v. Rogers, 457 U.S. 291, 299 (1982) (hospitalization).

${ }^{231}$ See Rogers, 457 U.S. at 303 (emphasizing that states may recognize broader liberty interests than those protected by the Constitution).

${ }^{232}$ See Rogers, 457 U.S. at 299 (assuming that the "Constitution recognizes a liberty interest in avoiding the unwanted administration of antipsychotic drugs" in the hospital context).

${ }^{233}$ Rogers, 457 U.S. at 300 (emphasizing that the state law in this instance, which appeared to require an "overwhelming State interest" to forcibly medicate, was broader than those rights protected by the federal Constitution); Gutterman, supra note 10, at 2418.

${ }^{234}$ See Riggins v. Nevada, 504 U.S. 127, 136 (1992) (O'Connor, J.) ("Contrary to the dissent's understanding, we do not 'adopt a standard of strict scrutiny."').

${ }^{235}$ Riggins, 504 U.S. at 138 (emphasis added).

236 Washington v. Harper, 494 U.S. 210, 226 (1990) ("[The prison policy] is a rational means of furthering the State's legitimate objectives."). 
tion is administered. The setting in which PVOT is administered is on an outpatient basis, but after a determination has been made that the individual meets PVOT criteria and is severely mentally ill. Therefore, this setting appears to be more analogous to the individual hospitalized or convicted of a crime than the individual awaiting trial in jail. This is because a determination that the individual is severely mentally ill has already been made, unlike the setting in which an individual, irrespective of mental illness, is presumed innocent and is waiting to be tried for a crime. ${ }^{237}$

Some scholars argue that the standard of review in an outpatient setting should be at least as great, and possibly greater, than the standard of review for those in a hospital or prison setting. ${ }^{238}$ But it could also be argued, to the contrary, that severely mentally ill individuals neither hospitalized nor incarcerated pose a higher risk ${ }^{239}$ to the public on the streets than when confined to the hospital or prison setting. Under this line of reasoning, after the state has proven by clear and convincing evidence that the individual is severely mentally ill and in need of PVOT, the level of scrutiny might be reduced rather than enhanced. In such an instance, akin to the standard of review of an individual who is hospitalized for his or her severe mental illness, the burden of proof would be on the severely mentally ill individual to prove that PVOT was not reasonably related to a legitimate state interest.

Additionally, legislative findings directly support that PVOT statutes seek to prevent inpatient hospitalization and incarceration, and in a sense replace these treatment avenues. Therefore, it is unclear as to why the standard of review would be higher for PVOT statutes in the outpatient setting. Further, since the right to refuse medication is not a "fundamental right" (when mental health is at issue $)^{240}$ strict scrutiny is not likely to be applied, and therefore, the government would only need to show a substantial (rather than compelling) or rational interest for the state to administer PVOT that is narrowly tailored to some degree. In sum, the precise standard of review to be applied to the right to refuse medication is in a PVOT setting is unclear, although it is likely to be somewhat deferential to the PVOT statute. ${ }^{241}$

Equal protection arguments are also often raised in challenges to involuntary treatment under state civil commitment statutes. The more interesting equal protection argument arises between different classes of mentally ill per-

${ }^{237}$ In Riggins, the defendant's mental health only became an issue after he was taken into custody. Riggins, 504 U.S. at 129.

${ }^{238}$ See Kristina M. Campbell, Note, Blurring The Lines of the Danger Zone: The Impact of Kendra's Law on the Rights of the Nonviolent Mentally Ill, 16 NOTRE DAME J. L. ETHICS \& PUB. POL'Y 173, 186-87 (2002).

${ }^{239}$ See supra Part III.D (discussing the relation between violence and severe mental illness).

240 See, e.g., Washington v. Harper, 494 U.S. at 223, 229; Mills v. Rogers, 457 U.S. 291, 299-300 (1982).

241 See, e.g., Washington v. Harper, 494 U.S. at 223; Rogers, 457 U.S. at 299-300. 
sons. For example, severely mentally ill persons subject to PVOT are arguably treated differently than those subject to inpatient treatment. There may be a persuasive justification, however, for the different classifications and treatments permitted under law. ${ }^{242}$ For instance, hospitalized mentally ill individuals have often met requisite dangerousness criteria, whereas individuals subject to PVOT and AOT might not always rise to the level of dangerousness. Yet the Court has continued to apply the rational review standard (or minimum scrutiny) ${ }^{243}$ to mentally ill individuals in Equal Protection cases and has not expressly applied either strict or mid-level scrutiny. For example, in City of Cleburne v. Cleburne Living Center ${ }^{244}$ the Court refused to formally apply a heightened standard of scrutiny to the developmentally disabled, even though the ordinance discriminating against such persons was ultimately invalidated under an unusually rigorous minimum scrutiny examination. ${ }^{245}$ Because minimum scrutiny is likely to be applied to different classifications of severely mentally ill persons, such challenges to statutes regarding these classifications will likely not prevail. ${ }^{246}$ This is because there are often legitimate (if not compelling or substantial) reasons why individuals with relevantly different mental illness should receive differing forms of psychiatric treatment.

Though PVOT has not yet reached the United States Supreme Court, In re K.L. is not the first constitutional attack on Kendra's Law in New York to be rejected. Kendra's Law has repeatedly been upheld as a constitutional exercise of state power in New York's lower courts. ${ }^{247}$ Nonetheless, In re K.L. is the first case that challenged the constitutionality of Kendra's Law to reach the New York Court of Appeals. ${ }^{248}$ As one academic stated:

With its decision in In re K.L[.], the Court has made it abundantly clear that Kendra's Law passes constitutional

242 See Cornwell \& Deeney, supra note 3, at 221.

243 In general rational review requires that the statute be rationally related to a legitimate state interest. E.g., City of Cleburne v. Cleburne Living Ctr., 473 U.S. 432, 440 (1985).

244 City of Cleburne, 473 U.S. at 432.

245 Id. at $442,448-450$.

246 Id. at 442; Watnik, supra note 222, at 1211-12.

247 E.g., In re Urcuyo, 714 N.Y.S.2d 862, 869, 873 (N.Y. Sup. Ct. 2000) (rejecting respondent's arguments that Kendra's Law violated due process and equal protection under both New York's constitution and the U.S. Constitution because a judicial finding of incapacity was not a criteria for treatment eligibility). N.Y. STATE OFFICE OF MENTAL HEALTH, KENDRA's LAW: FinAL REPORT ON THE STATUS OF ASSISTED OUTPATIENT TREATMENT app.2 at 35-53 (2005), available at $\mathrm{http}$ //www.omh.state.ny.us/omhweb/Kendra_web/finalreport/PVOTFinal2005.pdf (last visited Mar. 31, 2007) [hereinafter N.Y. REPORT ON KENDRA's LAw] (detailing the constitutional challenges to Kendra's Law). But see Perlin, supra note 3, at 200-02 (discussing the right to refuse medication).

248 N.Y. REPORT ON KENDRA's LAW, supra note 247, at 39. See also Paul S. Appelbaum, Assessing Kendra's Law: Five Years of Outpatient Commitment in New York, 565 PsYCHIATRIC SERVS. 791, 791 (2005). 
muster. Given its demonstrated effectiveness in improving outpatient outcomes for mentally ill patients and promoting public safety, there is little question that Kendra's Law will continue to be utilized to ensure public safety and patient health when mentally ill patients return to the community. ${ }^{249}$

In Matter of K.L. signals to other state and federal courts that PVOT statutes are likely to be constitutional in structure and practice. ${ }^{250}$

\section{REPORTS AND DATA ON THE EFFECTS OF PVOT STATUTES}

The most recent report on PVOT was published in March 2005, was authored by the New York State Office of Mental Health, and is titled "Kendra's Law: Final Report on the Status of Assisted Outpatient Treatment" ("N.Y. Report"). ${ }^{251}$ The N.Y. Report was statutorily required pursuant to the enactment of Kendra's Law. ${ }^{252}$ Several other research studies have been conducted to evaluate other types of AOT and OT laws that provide for conditional release, hospital diversion, or some variation of PVOT. ${ }^{253}$ But since these earlier studies were conducted prior to the specific PVOT statutes that this Note addresses, it is not clear how much weight should be placed on them. ${ }^{254}$ For instance,

249 Edward F. McArdle, 2003-2004 Survey of New York Law: Health Law, 55 SYRACUSE L. REV. 1107, 1141 (2005). See also Emily S. Huggins, Note, Assisted Outpatient Treatment: An Unconstitutional Invasion of Protected Rights or a Necessary Government Safeguard?, 30 J. LEGIS. 305, 316-17 (2004) (concluding that In re K.L. suggests that future challenges to the constitutionality of Kendra's Law will be struck down).

250 See In re K.L., 806 N.E.2d 480, 486, 487 (N.Y. 2004).

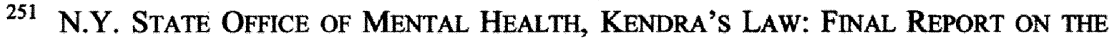
STATUS OF ASSISTED OUTPATIENT TREATMENT (2005), available at http://www.omh.state.ny.us/omhweb/Kendra_web/finalreport/PVOTFinal2005.pdf(last visited Mar. 31, 2007) [hereinafter N.Y. REPORT ON KENDRA'S LAW].

252 N.Y. REPORT ON KENDRA's LAW, supra note 251, at 1.

253 The New York Involuntary Outpatient Commitment Pilot Program (also known as the Bellevue Pilot Project) also studied AOT laws from 1995 to 1998 just prior to the adoption of Kendra's Law in 1999 but interestingly found no statistical evidence supporting the effectiveness of PVOT. O'Connor, supra note 3, at 326-27; see also Honig \& Stefan, supra note 3, at $111,114-15$.

254 For the most part, these prior studies found that assisted outpatient treatment works. See Honig \& Stefan, supra note 3, at 109; O'Connor, supra note 3, at 360 \& n.228. A 2001 meta-analysis study (of several other AOT studies) by RAND suggested that both the Duke Study and New York Pilot Study were flawed. Honig \& Stefan, supra note 3, at 114 \& 21. RAND is a non-profit research organization that reevaluates scientific studies for the purpose of identifying errors in data collection and conclusions. See generally RAND Corporation, Objective Analysis: Effective Conclusions, http://www.rand.org (last visited Feb. 20, 2006). The name RAND was derived from a merging of the terms research and development. Id. RAND's meta-analysis concluded that AOT was not effective in reducing hospitalization rates, as was suggested by both studies RAND reviewed. See Honig \& Stefan, supra note 3, at 114. The 
some of the earliest PVOT statutes, such as that of North Carolina, are similar to the specific statutes that this Note addresses, but over the last couple of decades have been updated procedurally and substantively. Hence, the N.Y. Report contains the most valuable and current research data concerning the effectiveness of PVOT statutes.

The N.Y. Report documents the empirical findings since the implementation of Kendra's Law in 1999, covering just over a five year period. The findings are derivative of three sources. First, an electronic tracking system was used in each county to compile basic information concerning each recipient's gender, illness, age, and court order. ${ }^{255}$ Second, paper-based surveys were used by case managers to collect data concerning the progress of recipients. ${ }^{256}$ Specifically, case managers were expected to keep assessments for each recipient at the critical intervals of treatment: 1) at the onset of the court order, 2) at the end of the initial court order, and 3) if the court order was renewed, then every six months for the duration of the order. ${ }^{257}$ Third, face-to-face interviews conducted by researchers and office staff were conducted with a sample of PVOT recipients in New York City. ${ }^{258}$

Overall, the N.Y. Report documents the widespread success of Kendra's Law throughout the state of New York, noting that recipients of PVOT "are able to make gains in their recovery process and maintain them over the duration of ... participation and beyond." ${ }^{, 59}$ As a result of these positive findings, the New York legislature deleted the initial 2005 sunset date of Kendra's Law and extended it to $2010 .{ }^{260}$ The New York Office of Mental Health had previously recommended, based on the N.Y. Report alone, that the New York legislature delete the sunset provision indefinitely and extend Kendra's Law permanently. ${ }^{261}$ In re-enacting another sunset provision to Kendra's Law, however, the legislature appears most interested in obtaining more data concerning Kendra's Law before making any more permanent amendments. This bolsters the argument more generally that states considering adopting PVOT should do so sooner rather than later in order to help further the data being compiled concerning the potential effectiveness or ineffectiveness of PVOT.

specific findings of the RAND analysis, however, may actually support the development of the recent PVOT statutes this Note addresses since they tend to require better monitoring of patients, which was one of the critiques of AOT. Cf. Honig \& Stefan, supra note 3, at 117.

255 N.Y. REPORT ON KENDRA's LAW, supra note 251, at 7.

256 Id.

257 Id.

258 Id.

259 Id. at 22.

260 Kendra's Law, ch. 158, 2005 N.Y. Laws 2740 (codified at N.Y. MENTAL HYG. LAw § 9.60 (McKinney 2006)) (stating that 2010 is the controlling sunset date unless amended or deleted prior to that date).

261 N.Y. REPORT ON KENDRA's LAW, supra note 251, at 22. 


\section{A. What Types of Severely Mentally Ill Persons-and How Many-Are Be- ing Treated Under PVOT?}

The N.Y. Report shows that PVOT recipients suffer from the most severe and debilitating Axis I mental illnesses. Seventy-one percent of PVOT recipients under Kendra's Law had a diagnosis of schizophrenia, and thirteen percent had a diagnosis of bipolar disorder. ${ }^{262}$ One study critiquing the effectiveness of general AOT laws concluded that AOT statutes could reduce readmissions only if they were "imposed upon individuals with psychotic-as opposed to affective-disorders." 263 The N.Y. Report supports this finding because almost three quarters of PVOT recipients had a diagnosis of the psychotic disorder schizophrenia. Further, recent research suggests that bipolar and depression may have psychotic or positive symptoms. ${ }^{264}$ Therefore we might assume that the percentage of PVOT recipients who have a primary diagnosis of an affective disorder, such as bipolar or depression, suffer from the most severe forms of these disorders, which might include psychotic symptoms. ${ }^{265}$

In terms of the sheer number of individuals receiving treatment through PVOT, less than half of the individuals who were referred to the N.Y. Mental Health Director for PVOT received a court order obligating them to enter treatment. $^{266}$ In total, 10,078 individuals were referred to determine potential eligibility for a court order (between 1999 and 2004) ${ }^{267}$ Petitions were filed to the court, however, for only 4,041 out of the 10,078 individuals referred, roughly forty percent of all persons referred. ${ }^{268}$ Of the petitions filed, court orders were issued for 3,766 individuals or thirty-seven percent of all persons referred or ninety-three percent of all individuals for whom petitions were filed. ${ }^{269}$ While ninety-three percent of individuals for whom petitions were filed received a PVOT court order, it should be kept in perspective that sixty percent of the individuals initially referred to the director never reached the court door. ${ }^{270}$

262 Id. at 9. "An estimated 4.5 million Americans today suffer from the severest forms of brain disorders, schizophrenia and manic-depressive illness ( 2.2 million people suffer from schizophrenia and 2.3 million suffer from bipolar disorder)." Treatment Advoc. Ctr., Homelessness, Incarceration, Episodes of Violence: Way of Life for Almost Half of Americans with Untreated Severe Mental Illness, http://www.psychlaws.org/generalresources/fact2.htm (last visited Mar. 31, 2007).

263 Honig \& Stefan, supra note 3, at 114 (two other criteria were mentioned).

264 See supra notes 58-59 and accompanying text.

265 In addition, fifty-two percent of all PVOT recipients had a diagnosis of concurrent substance abuse problems, which is often a mechanism for self-medicating a severe mental illness. N.Y. REPORT ON KENDRA's LAW, supra note 251, at 9.

266 See id. at 7.

267 Id.

268 Id.

269 See id.

270 See id. Additionally, it should be noted that the mean age of recipients was thirtyseven-and-a-half years. Id. at 9 . The majority of recipients, sixty-six percent, were men, and 
The fact that PVOT is being ordered for less than half of all petitions filed to the Director of Mental Health is the kind of evidence that suggests Kendra's Law is targeting a specific population of severely mentally ill individuals and is also narrowly tailored to achieve those goals. ${ }^{271}$

\section{B. How Long Are PVOT Treatment Orders Lasting: Are Patients Complying with Their Medication and Treatment Plans Under PVOT?}

Initial PVOT court orders under Kendra's Law are generally six months in duration. "Court orders, however, can be renewed and recipients may receive additional court orders after previous orders expire."272 Of the 3,766 individuals that received treatment in New York during the five year period, roughly one-third were treated for the duration of six months. ${ }^{273}$ Just over two-thirds of the 3,766 individuals, however, had their court orders renewed beyond the initial six months. ${ }^{274}$ The average treatment period for all 3,766 recipients was one year and four months. ${ }^{275}$

One of the critiques of PVOT statutes is that OT fails in the long-term because after initial treatments take place, mental health centers fail to follow up with recipients, and eventually lose track of patients. ${ }^{276}$ In undertaking a review of a key OT study, one group of prominent researchers determined that OT "could reduce readmissions and total hospital days, but only if court orders were sustained for more than 180 days [and] was combined with intensive treatment . ..."277 PVOT addresses these two concerns directly.

First, PVOT statutes permit renewal of treatment orders after the initial six month period, or roughly 180 days. $^{278}$ In fact, the N.Y. Report found that the average treatment period was one year and four months, far beyond the six month period. ${ }^{279}$ Second, PVOT provides intensive treatment programs. ${ }^{280}$

seventy-five percent of all recipients were single and had never been married. Id.

271 One might argue to the contrary, however, that most of the screening is being done at the Office of Mental Health and the courts appear to be granting most of the petitions-ninetythree percent of those received. But it is certainly possible that the Office of Mental Health is doing most of the screening and therefore that petitions are only being filed for those individuals the Office genuinely believes meet the criteria for PVOT.

272 N.Y. REPORT ON KENDRA's LAW, supra note 251, at 8; Kendra's Law, N.Y. MENTAL HYG. LAW $\S 9.60(\mathrm{k})$ (McKinney 2006); Laura's Law, CAL. WELF. \& INST. CODE $§ 5346(\mathrm{~g})$ (West Supp. 2007).

273 See N.Y. REPORT ON KENDRA's LAW, supra note 251, at 8 (reporting thirty-six percent were treated for six months).

274 Id. (stating sixty-four percent were treated longer than six months).

275 Id.

276 See Honig \& Stefan, supra note 3, at 114 (discussing RAND's meta-analysis of AOT statutes and the need for "intensive" treatment).

277 Id. (emphasis added).

278 Kendra's Law, N.Y. MENTAL HYG. LAw $§ 9.60(j)(2)$ (McKinney 2006); Laura's Law, CAL. Welf. \& INST. CODE $\S 5346(d)(5)(B)$ (West Supp. 2007).

279 See N.Y. REPORT ON KENDRA's LAW, supra note 251, at 8.

280 N.Y. MENTAL HYG. LAW § 9.60(a); CAL. WelF. \& INST. Code § 5348. See also N.Y. 
Unlike conditional release or hospital diversion laws, PVOT specifically monitors patients through a variety of mechanisms: case management programs, group and individual therapy, vocational planning, and also administering tests to ensure patients are adhering to their medication. ${ }^{281}$ Hence, PVOT has proven to be intensive, collaborative, and reliable. ${ }^{282}$

The N.Y. Report's general finding that patients were adhering to treatment on average for just over a year is powerful data for PVOT because it reveals that Kendra's Law is maintaining treatment regimens that are structured enough to keep recipients complying with treatment. ${ }^{283}$ The statistics proving patient adherence to treatment plans, which for the majority of patients spanned longer than one year, suggest that PVOT has the power to dramatically change and enhance the lives of severely and chronically mentally ill individuals. ${ }^{284}$ In turn, the general public is better protected from future harms that might have otherwise resulted from a mentally ill individual's failure to comply with his or her treatment. ${ }^{285}$

Additionally, for the 3,766 PVOT recipients in New York, adherence to medication doubled after six months of treatment, in comparison to prior adherence at the onset of PVOT. ${ }^{286}$ At the onset, thirty-four percent of individuals reported already adhering to psychiatric medication, though presumably still having extreme difficulties with living. ${ }^{287}$ But by the six month evaluation mark, sixty-nine percent of patients were adhering to their medication regimens. ${ }^{288}$ This is a thirty-five percent increase in medication adherence after six months of intensive PVOT treatment. ${ }^{289}$ In addition to medication adherence, there was an eighty-nine percent increase in participation with case management services, and a forty-seven percent increase with individual or group therapy. ${ }^{290}$ At the six month evaluation mark, there was also a reported twenty-two percent reduction in difficulties with social relations and a forty-four percent reduction for the incidence of harmful behaviors. ${ }^{291}$ Increases in medication adherence and reduction of overall harmful and anti-social behaviors suggest

REPORT ON KENDRA's LAW, supra note 251, at 11 tbl.5.

281 N.Y. MENTAL HYG. LAW $\$$ 9.60(a)(1) (defining “assisted outpatient treatment"); CAL. WELF. \& INST. CODE $\S 5348$. See also N.Y. REPORT ON KENDRA's LAW, supra note 251, at 11 tbl.5.

282 See N.Y. REPORT ON KENDRA's LAW, supra note 251, at 11 tbl.5.

283 See id. at 11 tbl.5, 12 fig.3. See also N.Y. MENTAL HYG. LAW $\$ 9.60(a)(1),(4)$ (describing the services provided under a PVOT order).

${ }^{284}$ See N.Y. REPORT ON KENDRA's LAW, supra note 251, at 11 tbl.5.

285 See id. at 16 tbl.9.

286 See id. at 11-12, 11 tbl.5, 12 fig.3 (stating that case managers' reports based on faceto-face interviews with the patients and urine samples were used to determine medication adherence).

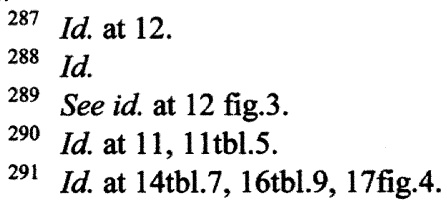


that during the first six months of PVOT patients improved substantially. ${ }^{292}$ Additionally, for those who had previously been hospitalized, there was a seventy-seven percent reduction rate in hospitalization. ${ }^{293}$

Additional AOT research studies have raised concerns as to whether AOT laws rely too heavily on medication, ${ }^{294}$ fail to ensure patient compliance with treatment, ${ }^{295}$ or fail to improve the quality of life of recipients. ${ }^{296}$ These assertions are each rebutted by the findings of the N.Y. Report. ${ }^{297}$ Furthermore, as mentioned previously, many AOT studies have not undertaken the specific procedures of PVOT statutes, or have done so in tandem with other branches of AOT such as conditional release and diversion statutes. Hence, researchers of PVOT should be wary when searching for studies regarding the general effectiveness of both AOT and PVOT statutes. Often, without explicitly mentioning it, these studies are reaching conclusions about conditional release programs from incarceration or hospital diversion programs rather than the forms of PVOT this Note addresses. While PVOT is a form of AOT, it is also a completely new branch of civil commitment. This is all the more reason that a new set of terms should be agreed upon by researchers to delineate the practices, so as not to cause further confusion in both legal and medical fields. ${ }^{298}$ As a final point, the N.Y. Report does not include data with respect to medication adherence after the first sixth months of treatment, ${ }^{299}$ however, other long-term improvements of recipients' conditions have been documented and are listed below.

${ }^{292}$ See id. at 12 fig.3, 17 fig.4, 10-16.

293 Id. at 17, 18tbl.10 \& fig.5 (rate based on the entire duration of PVOT).

294 Proponents assert that reliance on medication-based treatments encroaches on the liberties of mentally ill individuals, particularly due to serious side effects of certain psychiatric medications. For example, the FDA issued a Public Health Advisory in 2004 asking manufacturers of antidepressants to add warning statements concerning worsening depression or emergency suicide. E.g., Honig \& Stefan, supra note 3, at 116. Nonetheless, studies of antipsychotics, such as a Lancet's 2003 meta-analysis of the new generation of antipsychotics, have found that Clozapine is associated with fewer neurological side effects and higher efficacy than the older antipsychotics. Id.

295 Some studies have questioned whether AOT is effective in monitoring patients and keeping them compliant with treatment programs. Nonetheless, some of these same studies have found individuals who received extended AOT orders and intensive community services had significant increased compliance with treatment. See Honig \& Stefan, supra note 3, at 117 (citing Swartz et al. study).

296 These studies suggest that people subjected to AOT feel coerced and that homelessness, number of arrests, criminal victimization, violent behavior, and substance abuse are not different at the end of AOT compared to the beginning of AOT. See Honig \& Stefan, supra note 3 , at 118 .

297 See N.Y. REPORT ON KENDRA's LAW, supra note 251, at 10-14, 20-21.

298 See supra notes 35-39 and accompanying text (discussing various terms used to identify PVOT).

299 Compare with N.Y. REPORT ON KENDRA's LAW, supra note 251, at 12 (stating the medication adherence during the first six months). 


\section{What Are The Effects of PVOT on Incarceration Rates?}

For patients who had previously been incarcerated, the N.Y. Report documented an eighty-seven percent reduction in incarceration rates for PVOT recipients. ${ }^{300}$ Further, for those who had previously been arrested, though not incarcerated prior to their court order, there was an eighty-three percent reduction in the incidence of arrests in New York. ${ }^{301}$ These statistics suggest that New York's PVOT is having a large impact on reducing the incidences of "criminalization of the mentally ill" with Kendra's Law in place.

Criminalization of the mentally ill refers to the fact that "at least sixteen percent of the total jail and prison population in the United States, or nearly 300,000 people, have a serious mental illness . . ."302 The idea is that these individuals are effectively being incarcerated in the criminal system for their illnesses rather than aided with proper psychiatric treatment under a civil commitment statute. The national average of persons in prison or jail the United States with a serious mental illness is, sadly, more than four times higher than the total number of mentally ill persons in state mental hospitals in the United States. ${ }^{303}$ Additionally, statistics show that the vast majority of those jail inmates with serious mental illnesses have been arrested for non-violent misdemeanors such as trespassing, disorderly conduct, or alcohol and drug related charges. ${ }^{304}$ Thus, on a national average, under the danger-or-grave-disability statutes, we are effectively incarcerating our non-violent severely mentally ill rather than assisting them in receiving necessary treatment for their illnesses.

300 Id. at 18 tbl.10 \& fig.5. For patients who continued with PVOT after the first six months, reduction in harmful behaviors dropped to fifty-eight percent. Id. at 20 fig.8.

${ }^{301}$ Id. at 18 tbl. 10 \& fig.5.

302 Treatment Advoc. Ctr., Criminalization of Americans with Severe Mental Illnesses, at

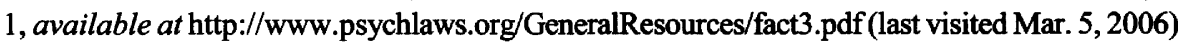
[hereinafter Treatment Advoc. Ctr., Criminalization of Severe Mental Illnesses] (citing 1999 U.S. DEP'T OF JUSTICE REPORT) (emphasis added).

303 Id.

304 Id. at 2. See also Pete EARLEy, Crazy: A Father's SEARCh Through AMErica's MENTAL HEALTH MADNESS 52, 119 (2006) (non-fiction book exploring the criminalization of the mentally ill in the Miami area and at the Miami-Dade prison). "Gilbert," whom Earley met on the psychiatric wing of the Miami-Dade prison, had been arrested twenty times in the past six years for trespassing, panhandling, and defecating in public. Id. at 52. In Los Angeles County, two-thirds of inmates who were reported to have mental illnesses had been incarcerated for nonviolent crimes. Steve Lopez, Mentally Ill in the Jail? It's a Crime, L.A. TimES, Dec. 11, 2005, at B1. "The jailhouse, in fact-despite the horrors and staffing problems-is one of the few places where mental health care is available." Id. at B13. Severely mentally ill persons who are arrested for traditional felony crimes, however, may have been led to do so due to a psychotic outbreak. WEGKAMP, supra note 116, at 32,38 (describing the true story of his then twentyyear-old son Chad who robbed a bank to raise adequate funds because he believed he needed a medical surgery to eliminate emerging voices in his head); EARLEY, supra note 304, at 20-21 (describing the story of his severely mentally ill son, a recent college graduate, who broke into a residential home but instead of stealing items ended up taking a bubble bath). 
Without PVOT, this population of severely mentally ill individuals will not receive involuntary treatment because they fail to meet the imminent or substantial risk tests of the danger-or-grave-disability statutes.

Jail or prison, even for a short period, is often a lethal setting for an individual with a mental illness for several reasons. ${ }^{305}$ First, mentally ill individuals are often victims of violence and abuse in prison due to their mental weaknesses and susceptibilities. ${ }^{306}$ Second, suicide by inmates with schizophrenia or manic-depressive illness in jails is more common than suicide among those without mental illnesses. ${ }^{307}$ Third, illogical thinking, delusions, auditory hallucinations, and severe moods swings often lead to bizarre behavior by severely mentally ill persons in jails and prisons, making them more susceptible to solitary confinement or breaking prison rules and receiving additional punishment. ${ }^{308}$ Fourth, there is often a lack of psychiatrists to treat the prison inmates since prison is not first-and-foremost considered a mental health treatment facility. ${ }^{309}$ Fifth, jail and prison formularies often are unable to accommodate cer-

305 See TORREY, OUT OF THE SHADOWS, supra note 74, at 31-35 (1997) ("Being in jail or prison when your brain is playing tricks on you is often brutal.").

${ }^{306}$ Due to a shortage of space in Los Angeles County Jails, on November 16, 2005, thirty-five year old mentally ill Shane Cochran was placed in a group jail setting and was beaten to death after being tortured. Lopez, supra note 304, at B1. " 'He was a fish out of water ... These inmates were sharks, and he was in the shark tank." Id. (quoting L.A. County Sheriff Lee Baca). See generally EARLEY, supra note 304, at passim (providing a vivid glimpse into the lives of the severely mentally ill who are incarcerated). Severely mentally ill prisoners also may be preyed upon for information related to their charges in order to get other prisoners' sentences reduced. E.g., WEGKAMP, supra note 116, at 134 (describing how Chad told an older inmate about the robbery he committed while in jail and the inmate handed the information over to the prosecutor).

307 A study of New York State jails between 1977 and 1982 reported that half of all inmates who committed suicide had previously been psychiatrically hospitalized. Treatment Advoc. Ctr., Criminalization of Severe Mental Illnesses, supra note 302, at 2. A recent federal lawsuit against the Indiana prison system, which ended in a beneficial settlement for severely mentally ill prisoners, alleged that "years of isolation in [7-foot-by-12-foot] windowless cells led four mentally ill inmates to kill themselves since 2000 and others to attempt suicide, hallucinate or rip chunks of flesh from their bodies." Brendan O'Shaughnessy, Cells Will Open for Isolated Inmates: Mentally Ill Prisoners Have been Confined 23 Hours a Day, But That Will Change, INDIANAPOLIS STAR, June 2, 2006, at A1; Jon Murray, Prison pact a win for mentally ill; Deal limiting use of maximum-security cells is a good first step, advocates say, INDIANAPOLIS STAR, Feb. 5, 2007, at B1. See also EARLEY, supra note 304, at 296 (telling the true story of "Weaver," a severely mentally ill individual who dove head-first off his bunk in prisonpresumably to commit suicide-and survived as a quadriplegic).

308 Treatment Advoc. Ctr., Criminalization of Severe Mental Illnesses, supra note 302, at 3; William Kanapaux, Guilty of Mental Illness, PsychiATRIC TimES, Jan. 2004, at http://www.psychiatrictimes.com/p040101a.html. See also EARLEY, supra note 304, at 46, 24042 (describing the tragic account of several uneducated prison guards at the Miami-Dade county jail psychiatric floor who beat a mentally ill individual due to their fear of severely mentally prisoners more generally, which was expressed by one of the guards in the following words: “ '[with] crazy inmates . . . if you don't scare them, then they will hurt you"').

${ }^{309}$ EARLEY, supra note 304, at 57 (documenting a prison psychiatrist who makes the 
tain prescriptions inmates may already be receiving outside of prison. Therefore, mentally ill prisoners are often switched to older and cheaper drugs that may have increased side effects and be less effective than other prescription drugs. ${ }^{310}$ Sixth, inmates are typically prohibited from speaking or visiting with family or friends, except at rare and designated visiting hours. ${ }^{311}$ Seventh, the physical design of incarceration - a system designed to punish and deterfurther antagonizes the development and deterioration of mental illness generally. ${ }^{312}$ Yet despite all these reasons, the severely mentally ill more often wind up being "treated" in prison or jail rather than through the civil system.

PVOT statutes aim to alleviate criminalization of the mentally ill. They seek to rehabilitate such individuals rather than incarcerate them, ultimately reducing costs in prison settings as well. The N.Y. Report illustrates how Kendra's Law is seeking to eliminate the number of severely mentally ill persons who are incarcerated due to their illness. ${ }^{313}$

\section{What Are the Effects of PVOT on Rates of Homelessness?}

The N.Y. Report showed a seventy-four percent reduction in the incidence of homelessness beyond the six month treatment period for those who reported being homeless at the beginning of PVOT. ${ }^{314}$ These statistics reveal that PVOT has the capacity to bring a halt to, what some have termed, the revolving-door phenomenon at work in the failures of the mental health system. ${ }^{315}$ This revolving-door refers to the cycling of mentally ill persons through jail, homelessness, and hospitalization due to inadequate mental health care systems. $^{316}$ The N.Y. Report is one of the first to specifically link PVOT to this type of socio-economic data. The results are an impressive model for other jurisdictions, especially large metropolitan areas. Nonetheless, more data needs to accumulate to either support or refute the results of the N.Y. Report. A criti-

early morning rounds visiting ninety-two psychiatric inmates at roughly 12.7 seconds per inmate; the doctor is saddened that there are not more psychiatrists on staff and that he cannot provide better care for them by telling Earley, “ 'Mentally ill people don't belong in jail . . . By its very design, a jail like ours is intended to dehumanize and humiliate a person.... This sort of atmosphere is counter to treatment or helping to improve anyone's mental health ....'”).

${ }^{310}$ E.g., id. at 54 (describing an account of an inmate at Miami-Dade who tells the prison psychiatrist that he is bipolar and taking Zyprexa, but the prison does not prescribe it to him because the psychiatrist is required to prescribe Risperdal first as it is less expensive).

311 WEGKAMP, supra note 116, at 73-77, 93, 161 (describing the family's frustration at being prohibited from visiting their mentally ill son in prison except for brief thirty minute phone visits-behind a glass wall-once a week).

312 See EARLEY, supra note 304, at 45, 47 (describing the unsanitary conditions at the Miami-Dade county jail on the psychiatric floor, which arguably speed up the development of a severe mental illness).

${ }^{313}$ N.Y. REPORT ON KENDRA's LAW, supra note 251, at 18 tbl.10 \& fig.5.

314 Id.

315 See, e.g., Kress, supra note 24, at 1273.

316 See id. (stating that the revolving-door phenomena refers to mentally ill persons who "continuously revolve in and out of hospitals"). 
cism of the N.Y. Report is that it is based on only the first five years of data. ${ }^{317}$ Further, adherence to treatment past the initial six months is still largely unknown and needs to be monitored.

Several researchers have suggested that one reason why there are so many mentally ill homeless persons today is a result of the deinstitutionalization movement, which began in the mid-1950s. During this movement, accelerated by the Medicaid exclusion, ${ }^{318}$ numerous patients were released from hospitals, and sometimes the mental hospitals themselves were shut down. To illustrate, in 1955 , the United States had 558,239 patients in state and county psychiatric hospitals, when the total population was 164 million. ${ }^{319}$ But by 1996 , the number of patients in state and county psychiatric hospitals had dropped to only 61,722 in a population that had increased to 265 million. ${ }^{320}$ This is a dramatic ninety-three percent reduction rate in the hospitalization of the mentally ill. ${ }^{321}$ While a return to the horrors of institutionalization is certainly not the answer today, these dramatic figures hint that a substantial number of persons, especially in light of population increases, may be in need of mental health treatment. Instead, a large percentage of such persons may be living on the streets.

In general, the majority of homeless persons are not homeless due to a mental illness and are typically homeless for only a short period of time, often attributed to an unexpected event such as an eviction, natural disaster, or house fire. ${ }^{322}$ Nonetheless, those who are homeless for longer periods, including the chronically homeless, tend to have disabling health problems, such as mental illness. $^{323}$ Of the estimated 200,000 people who experience chronic homelessness, at least twenty percent have serious mental illness. ${ }^{324}$

317 See N.Y. REPORT ON KENDRA's LAW, supra note 251, at 1, 5, 7.

318 See supra note 12.

319 Davoli, supra note 9, at $174 \&$ n. 84 (quoting Treatment Advoc. Ctr., Briefing Paper: Repeal of the Institutions for Mental Disease Exclusion, available at http://www.psychlaws.org/HospitalClosure/Repeal.htm (last visited Apr. 11, 2007)).

320 Id.

321 Id.

322 U.S. Dep'T HeAlth \& Human SERvs., Blueprint for ChANGE: Ending Chronic HOMELESSNESS FOR PERSONS WITH SERIOUS MENTAL ILLNESS AND/OR CO-OCCURRING SUBSTANCE USE DISORDERS 3 (2003), available at http://download.ncadi.samhsa.gov/ken/pdf/SMA043870/SMA04-3870.pdf [hereinafter ENDING CHRONIC HOMELESSNESS FOR PERSONS WITH SERIOUS MENTAL ILLNESS].

${ }^{323}$ Id.

${ }^{324}$ Id. Los Angeles County recently released its 2005 report on homeless populations. L.A. HOMELESS SERVS. AUTH., 2005 GREATER LOS ANGELES HOMELESS COUNT (2006), available at http://www.lahsa.org/homelesscount/pdfs/LAHSA\%20Report\%20-\%20Final\%20Version64.pdf [hereinafter L.A. HOMELESS SERVS. AUTH.]. Of the total 82,291 homeless individuals at any given point in time in Los Angeles County, over thirty-four percent reported to be experiencing mental illness. Id. at 3, 8. This is a higher percentage than suggested by the United States Department of Health and Human Services' national survey of the homeless who are mentally ill. ENDING Chronic Homelessness for PERsons WITH Serious MENTAL Illness, supra note 322 (estimating twenty percent). The Los Angeles Report noted that approximately 
Additionally, "as many as two-thirds of all people with serious mental illnesses have experienced homelessness or have been at risk of homelessness at some point in their lives. ${ }^{325}$ There are several reasons why severely mentally ill persons might have difficulty obtaining stable housing over the course of a developing lifelong illness. Mentally ill individuals may be evicted from apartments for actions such as disturbing neighbors, missing rent or utility payments, and neglecting general housekeeping. ${ }^{326}$ Eviction may also result from a difficulty in developing and maintaining comfortable social relationships with other tenants or neighbors. ${ }^{327}$ Mentally ill individuals may become lonely and isolated, and often have social conflicts with family, employers, landlords, and neighbors. ${ }^{328}$ Also, mentally ill persons who are subject to hospitalization or incarceration may lose their housing when they are unable to pay rent during such periods. ${ }^{329}$ Mentally ill persons may also have difficulty in both obtaining and maintaining employment due to their illnesses, and therefore may be unable to pay utilities or rent payments. Discrimination and stigma associated with mental illness, coupled with homelessness, are often significant impediments to accessing housing. ${ }^{330}$ Furthermore, mentally ill homeless individuals may also become victims of assault on the streets or in shelters, and may be ill equipped to defend themselves in a life threatening situation due to their illnesses. ${ }^{33}$

Lack of economic resources or low socio-economic status, however, does not correlate with homeless persons who are mentally ill. ${ }^{332}$ This tends to suggest that personal financial resources are not the cure for such a mentally ill individual's illness or chronic homelessness. Additionally, mentally ill individuals may be homeless due to choice, or due to their self-perceived inability to live near others stemming from unwanted delusions and hallucinations. Such an individual may genuinely be happier (amidst the illness), regardless of how much money he or she has, to remove him-or-herself from society altogether. Hence the root cause of chronic homelessness as it intersects with per-

fifty percent $(34,512)$ of the homeless were experiencing "chronic homelessness." L.A. HOMELESS SERVS. AUTH., supra note 324, at 6. Chronic homelessness was defined as "[a]n unaccompanied individual with a disabling condition who has been continually homeless for one year or more, or has experienced four or more episodes of homelessness within the past 3 years." Id. at 6. The Los Angeles Report supports national statistics regarding the correlation of homelessness and mental illnesses, and in addition to being the most recent and thorough study of homelessness in a large metropolitan area, suggests that combating mental illness may alleviate some of the percentages of those who are chronically homeless.

325 HOMELESS SERVS. AUTH., supra note 324, at 12.

${ }^{326}$ Id. at 12. E.g., Michael Jenuwine \& Robert Jones, Professors of Law, University of Notre Dame University Law School, Panel Address at Norman Amaker Public Interest Law and Social Justice Retreat: Seeking Justice for People with Mental Illness (Feb. 24, 2007).

${ }^{327}$ HOMELESS SERVS. AUTH., supra note 324, at 12.

328 Id.

329 Id. at 13.

$330 \mathrm{Id}$. at 25

${ }^{331}$ See id. at 15.

${ }^{332}$ Davoli, supra note 9, at 176. 
sons who are mentally ill may simply be the severity of the illness itself. Addressing the illness first and foremost through statutes such as PVOT seems to be an appropriate step in remedying the problem of the mentally ill who are homeless.

\section{E. Other Benefits of PVOT}

New York counties also reported that the implementation of PVOT resulted in beneficial structural changes to local mental health service delivery systems. ${ }^{333}$ The N.Y. Report identified three beneficial administrative changes: "[1] ... enhanced accountability in local mental health service systems. ... [2] improved access to services for high need individuals, ... [ [and 3] the development of more collaborative relationships between the mental health and court systems."334 Hence, the structure and detailed procedures of PVOT improved the general quality of mental health care throughout the state of New York. ${ }^{335}$

Additionally, in compiling data for the N.Y. Report, patients themselves were surveyed and asked about how they felt about their experience with PVOT. Certainly, some patients reported that being court-ordered for purposes of receiving psychiatric treatment was an embarrassing and humiliating event, yet sixty-two percent of patients reported that being court-ordered into treatment was an overall "good thing." 336 Of this sixty-two percent, additional positive responses regarding treatment were reported. Eighty-one percent reported that "the pressures or things people have done to get them to stay in treatment helped them to get and stay well.",337 Seventy-five percent reported that treatment helped them gain control over their lives. ${ }^{338}$ Ninety percent reported that treatment had made them more likely to keep appointments and take medication. ${ }^{339}$ And eighty-eight percent reported that they trusted their case managers and felt good that they also had a role in determining their own treatment plan. ${ }^{340}$ While thirty-eight percent of patients appeared not to have a positive response to PVOT, the majority of the patients in the end felt positive about the treatments they were receiving, though it was no doubt a very difficult emotional process.

In sum, the N.Y. Report provides positive and promising evidence to link to the current policy efforts to implement PVOT statutes. The results suggest that PVOT is targeting a specific population of severely mentally ill individuals, is helping to assist these individuals with treatment, and at the same time is im-

337 Id. at 20-21.

$338 I d$. at 21.

339 Id.

340 See id. 
proving the mental health delivery system.

\section{The TRUTH BEHIND LAURA'S LAW-THE CALIFORNIA GHOST LAW}

Unlike Kendra's Law, which automatically became the law in the entire state of New York upon its enactment (and was sufficiently funded to do so), ${ }^{341}$ Laura's Law has not been adopted on a state-wide basis in California. ${ }^{342}$ Instead, Laura's Law has been enacted with a provision that makes it optional for counties to adopt it. ${ }^{343}$ Therefore, if a California county chooses to adopt the law, ${ }^{344}$ that county alone is required to provide the funds for the PVOT treatment plans as well as adhere to specific requirements regarding provider services according to state law. ${ }^{345}$

341 For example, during the fiscal year of 2005-2006 New York Governor George E. Pataki budgeted thirty-two million dollars for the operation of services in support of Kendra's Law. See id. at 2. During that same fiscal year, Governor Pataki also budgeted more than $\$ 125$ million to "expand the capacity of the existing community-based mental health system and to strengthen the cohesiveness and coordination of that system." Id. at 3.

342 Laura's Law, CAL. WELF. \& INST. CODE $\S \S 5346$ (a), 5348 (West Supp. 2007). The mental health system in California, however, is statutorily authorized and financed on a countyby-county basis. See Bronzan-McCorquodale Act, CAL. WeLF. \& INST. CODE $§ 5600$ (West 1998).

${ }^{343}$ Id. One unique issue that Laura's Law's county-enactment provision seems to suggest is that persons in different counties throughout the state who are severely mentally ill may be subject to radically different types of treatment throughout the same state. See generally CAL. WELF. \& INST. CODE $§ 5600$ (authorizing a county-by-county mental health care system in California). So a person in Los Angeles County might be able to receive PVOT (if the county had adopted it) but a person in Alameda County might not (assuming PVOT were not adopted). Therefore it might be said that the state of California is denying the equal protection of severely mentally ill persons throughout the state under the optional county provision, in which geographic county location determines the level and type of psychiatric treatment. But the United States Supreme Court has never held that mentally ill persons constitute a suspect classification, which would implicate mid-level or strict scrutiny of the county provision. See supra Part VII and notes 231, 243-44 and accompanying text. Even so, similar to City of Cleburne v. Cleburne Living Ctr., 473 U.S. 432 (1985), a heightened level of rational review would likely be applied to evaluate the constitutionality of the county provision. See supra Part VII and notes 244-46 and accompanying text. Under a heightened rational review standard, a court would likely find that the state of California has a rational interest in enacting Laura's Law on a county basis that is reasonably tailored to the state's objectives. Namely, California lacks the resources to implement Laura's Law on a statewide basis and counties are arguably the best judges of how their mental health systems should be run.

344 In Los Angeles County there are five members of the Board of Supervisors who made the decision to implement Laura's Law and finance it on behalf of Los Angeles County. Telephone Interview with Kirsten Deichert, Legislative and Public Information Officer, L.A. County Department of Mental Health, in L.A., Cal. (Jan. 2006). Other counties in California that wish to implement Laura's Law should contact their county Board of Supervisors. TREATMENT Advoc. Ctr. \& Cal. Treatment Advoc. Coal., A Guide to Laura's Law: California's New LAW FOR ASSISTED OUTPATIENT TREATMENT 15 (2d ed. 2003).

345 CAL. WELF. \& INST. CODE $§ 5348(a)-(d)$. 
For example, Laura's Law requires that each county provide mental health teams that have no more than ten patients per mental health provider. ${ }^{346}$ While the small patient to provider ratio creates an optimal health care setting for mental health providers and patients, in reality, this is extremely costly and difficult to follow for counties with limited resources. Quite possibly, even the standard influx of employees that may leave a mental health hospital would have the power to make any county's use of Laura's Law unlawful and in violation of the statute. Additionally, Laura's Law requires that counties must provide the following mental health services under PVOT: 1) outreach to families whose severely mentally ill relative lives with them as well as family support services generally $;^{347} 2$ ) staff with the cultural background and linguistic skills necessary to help patients who cannot speak English; ${ }^{348} 3$ ) therapy that employs psychosocial rehabilitation, ${ }^{349} 4$ ) services aimed to help mentally ill adult individuals age twenty-five or younger who are at a significant risk of becoming homeless; ${ }^{350} 5$ ) services reflecting the special needs of women, including issues such as domestic violence and raising children; ${ }^{351} 7$ ) supportive housing that is immediate, transitional, and/or permanent; ${ }^{352}$ and 8 ) a designated mental health personal services coordinator for each patient. ${ }^{33}$ To the extent feasible, Laura's Law requires that counties design treatment programs that include the following services: 1) vocational counseling and academic planning, ${ }^{354}$ 2) maintenance of and access to physical health care; ${ }^{355}$ and 3 ) substance abuse counseling. ${ }^{356}$ Furthermore, each county that adopts Laura's Law must provide data to the State Department of Mental Health that will generate an annual report to the legislature concerning Laura's Law. ${ }^{357}$ The report must include the following (creating yet another expense for counties, ${ }^{358}$ though certainly crucial to evaluating the success or failure of the law): 1) the number of patients receiving

${ }^{346} I d . \S 5348(a)(1)$. Compare with Kendra's Law, N.Y. MENTAL HYG. LAw $\S 9.60(a)(1)$ (McKinney 2006). See also N.Y. MENTAL HYG. LAW $§ 41.42$ (family support programs); $\S$ 41.39 (vocational programs); $\S 41.13$ (powers and duties of local government units).

${ }^{347}$ CAL. WELF. \& INST. CODE $\S 5348(a)(2)(B),(E)$.

$348 \quad I d . \S 5348(\mathrm{a})(2)(\mathrm{B})$.

349 Id. $\S 5348(\mathrm{a})(2)(\mathrm{F})$.

350 Id. $\S 5348(\mathrm{a})(2)(\mathrm{H})$.

351 Id. $\S 5348(\mathrm{a})(2)(\mathrm{I})$.

${ }^{352} I d . \S 5348(\mathrm{a})(2)(\mathrm{J}),(4)(\mathrm{A})$.

${ }^{353}$ Id. $\S 5348(\mathrm{a})(3)$.

${ }^{354}$ Id. § 5348(a)(4)(B), (D), (E).

355 Id. $\S 5348(\mathrm{a})(4)(\mathrm{G})$.

356 Id. § 5348(a)(4)(J).

${ }^{357}$ Id. $\S 5348(\mathrm{~d})$.

358 Cf. Barbara A. Collins, Mental Health Court Judge, Marion County, Ind., Remarks at Starting a Mental Health Court in Your Community, Panel Speaker at the 4th Annual Mental Health \& Criminal Justice Summit, Indianapolis (Mar. 23, 2007) (stating that the cost of keeping data concerning a judge-driven mental health court is nearly impossible without increased funding). 
PVOT; ${ }^{359} 2$ ) the number of patients with a criminal history and the extent to which criminal behaviors are reduced with the implementation of PVOT; ${ }^{360} 3$ ) number of persons participating in employment programs; ${ }^{361} 4$ ) days of psychiatric hospitalization that have been reduced or avoided; ${ }^{362} 5$ ) medication adherence rates; ${ }^{363} 6$ ) violent acts committed by persons in the program; ${ }^{364} 7$ ) substance abuse reduction rates; ${ }^{365} 8$ ) social functioning of persons in the program; ${ }^{366}$ and 9) reports from patients and family members as to the success or failure of PVOT. ${ }^{367}$ Additionally, any California county that wishes to adopt PVOT must provide all of the same services on a voluntary basis. ${ }^{368}$ Therefore, any county that wishes to adopt PVOT in order to target the population of persons who are severely mentally ill and arguably lack insight into their illnesses must also equally provide such services to persons who meet the criteria but wish to obtain the treatment voluntarily.

Based on the laundry list of requirements Laura's Law imposes on counties that choose to adopt PVOT (though it is a very positive laundry list), it is easy to see how very quickly the adoption of Laura's Law in any given county effectively requires an expensive renovation of an entire mental health service delivery system. While this is a noble undertaking that should be encouraged, it is also extremely expensive for most counties to undertake single-handedly without state-wide financial support. Many California counties are already under-budgeted for mental health care services and are trying to do the best they can with the resources available. ${ }^{369}$ Therefore, Laura's Law's mental health services requirements seem to set up an unfortunate barrier to the implementation of Laura's Law in California, provided that the state continues to place the entire financial responsibility in the laps of local counties.

Los Angeles County is the only one of the fifty-eight counties in Califor-

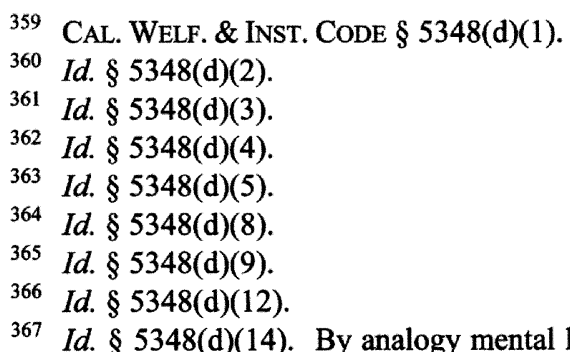
sources to keep such data on those that are diverted though their courts. Mental Health Court Panel at the 4th Annual Mental Health \& Criminal Justice Summit, Indianapolis (Mar. 23, 2007).

368 CAL. WeLF. \& INST. CoDE $\S \S 5347(a)$, 5346(e)(1)-(2); see also E-mail from Rusty Selix, Executive Director, Mental Health Association in California (Mar. 11, 2007, 10:42:16 EDT) (on file with author).

369 Scott Gold, Lee Romney \& Evan Halper, Program for mentally ill eliminated; Before signing the budget, Schwarzenegger kills the \$55-million initiative that aids the homeless. Counties can fund it, an aide says., L.A. TIMES, Aug. 25, 2007, at B1 ("Counties across... [California] are facing the slow erosion of their traditional mental health budgets.”). 
nia that has attempted to implement Laura's Law. ${ }^{370}$ Nevada County, the county in which Laura Wilcox was murdered by a man suffering from schizophrenia, has also taken a close look at adopting the law, though it has not as yet done so. ${ }^{371}$ Nonetheless, Los Angeles County's attempt at implementing Laura's Law has been extremely limited, but not limited enough to fail to stirup major controversy within the state and instigate a lawsuit against the county that ended in settlement. Ultimately, Los Angeles County's use of Laura's Law has proven, for the most part, nearly nonexistent. ${ }^{372}$ This effect seems to have trickled over and throughout the rest of the state.

The program to implement Laura's Law in Los Angeles County was not technically Laura's Law as we know it. Rather, it was a voluntary pilot program with a few of the same concepts since the county was not able to fund a full adoption of the law. ${ }^{373}$ In effect, the partial adoption excluded the core language and purpose of Laura's Law, acting more as a diversion program for persons already in the criminal justice system..$^{374}$ Nonetheless, the partial adoption may have proven to be more legally problematic than Los Angeles County ini-

${ }^{370}$ See County of L.A., State of Cal., Resolution Implementing A Pilot Project of "Laura's Law" (Assembly Bill 1421): "Assisted Outpatient Treatment" (2002) (on file with author); County of L.A., State of Cal., Minutes of the Board of Supervisors (Oct. 7, 2002) (on file with author); Letter from Marvin J. Southard, Director of the Department of Mental Health in the County of L.A., to Each Supervisor of L.A. County (Nov. 5, 2002) (on file with author) ("To comport with the spirit of the statute, but given the fiscal and program restraints at this time, DMH proposes a limited implementation of AOT in collaboration with the Superior Court. DMH proposes that intake to the AOT program exist for individuals who are exiting the criminal justice system with relatively minor offenses."); Letter from Marvin J. Southard, Director of the Department of Mental Health in the County of L.A., to Supervisors of L.A. County (Jan. 16, 2003) (on file with author) (recommending that the Board of Supervisors adopt the pilot project of Laura's Law). Contra Cal. Network of Mental Health Clients, AB 2357-Why Oppose It, supra note 200 (arguing that the law was never formally adopted).

371 Cal. Network of Mental Health Clients, AB 2357-Why Oppose It, supra note 200. Some have argued Nevada County's attempts to implement the law are part of a settlement agreement with Laura Wilcox's family over her death. Id. See also Dave Moller, Second Try for Laura's Law: It is Hoped New Version Will Retire Sunset Date, Add Funds, THEUNION.COM, Mar. 2, 2006, at $h t t p: / / w w w . t h e u n i o n . c o m / a r t i c l e / 20060302 / N E W S / 103020136$ (stating Nevada County was hoping to use Proposition 63 funds to implement it).

372 See Fritz, supra note 8, at A12 (suggesting Laura's Law has yet to be used even in Los Angeles County).

373 See CAL. WELF. \& INST. CODE $§ 5347$ (adopting only the subsection, titled "Voluntary Treatment; Settlement Agreements," made it possible for Los Angeles County to use Laura's Law to divert some severely mentally ill persons from the criminal justice system to the mental health system arguably without adopting the subsections that included eligibility criteria and third party petitions). See also Complaint for Declaratory and Injunctive Relief and Petition for Writ of Mandate at 7, Cal. Network of Mental Health Clients v. County of L.A. (No. BC310719) (Super. Ct. Cal., L.A. County, Feb. 18, 2004) [hereinafter Complaint].

374 E-mail Attachment from Alisa Dunn, Director, L.A. County Mental Health Department, Voluntary Assisted Outpatient Treatment Program (Mar. 27, 2007, 04:55:31 EDT) (on file with author). 
tially realized. ${ }^{375}$

A lawsuit was filed against Los Angeles County, the Los Angeles County Board of Supervisors, and the Los Angeles County Department of Mental Health by a non-profit mental health organization that is politically against involuntary treatment and Laura's Law. ${ }^{376}$ The Complaint alleged that the defendants of Los Angeles County had arbitrarily operated an involuntary PVOT program because Laura's Law only permits PVOT if express statutory criteria are met. ${ }^{377}$ Even though the lawsuit ended in settlement, ${ }^{378}$ it is certainly possible that Los Angeles County had not carefully adhered to all of the arguably expensive and expansive criteria required by Laura's Law. These criteria included meeting the detailed service provider requirements ${ }^{379}$ as well as providing voluntary services to persons selected for PVOT. ${ }^{380}$

Specifically, plaintiffs alleged that the persons whom Los Angeles County had selected for PVOT were never offered PVOT on a voluntary basis because they were already in the criminal justice system when PVOT was offered. ${ }^{381}$ Hence, PVOT was being used as a device to divert them from charges or jail, and was arguably not being offered simultaneously on a true voluntarily basis. ${ }^{382}$ Additionally, the Complaint alleged that Los Angeles County was selectively hand-picking those persons that it wanted to divert through PVOT based on open-seat availability, thereby not offering it to all persons who might otherwise qualify under Laura's Law. ${ }^{383}$ This is the way that many mental health courts currently lawfully operate throughout the country today, but because Los Angeles County chose to implement this diversion program under the guise of aspects of Laura's Law, this posed legal problems that many other counties throughout the country would not have endured. The Complaint further alleged more generally that

${ }^{375}$ Complaint, supra note 373, at passim. The L.A. County Program was effective in 2003. Id. at 9.

${ }_{376}$ Id. at passim; see generally Cal. Network of Mental Health Clients, Policy Arguments Against Implementation of AB 1421, http://www.californiaclients.org/policy/policy_arguements.cfm (opposing Laura's Law) (last visited Apr. 1, 2007); Cal. Network of Mental Health Clients, AB 2357-Why Oppose It, supra note 200 (opposing Laura's Law).

377 Complaint, supra note 373, at 2.

378 See Final Settlement Agreement and General Release, Cal. Network of Mental Health Clients v. County of L.A. (No. BC 310719) (Sept. 28, 2005) (on file with author) [hereinafter Final Settlement Agreement].

379 Complaint, supra note 373, at 6,9. See also CAL. WeLf. \& INST. CodE § 5348(a)

(West Supp. 2007). See supra notes 344-51 and accompanying text.

${ }^{380}$ Complaint, supra note 373 , at 9.

381 Id. at 7, 9.

382 Id. at 7-8. Los Angeles County's Program was to exist for individuals found to be incompetent to stand trial in misdemeanor cases. Id. at 8.

${ }^{383}$ Id. at 9 ("Based on information and belief, defendants will offer voluntary services to persons subject to a ... [PVOT] investigation only if there are slots available under the county's existing ... programs ...."). 
[d]efendants' actions and inactions force persons with psychiatric disabilities into unnecessarily restrictive settings instead of providing appropriate outpatient treatment, erode mental health client trust, infringe on the fundamental right to privacy and informed choice, perpetuate discrimination and stigma, undermine statutorily mandated court processes, and threaten to increase police detention of people with psychiatric disabilities for petty offenses to obtain appropriate services. ${ }^{384}$

Defendants responded by ducking most of the substantive issues raised by the Complaint and focusing on procedural issues in hopes of a judgment at the pleading stage in their favor. ${ }^{385}$ They also highlighted the recently upheld constitutionality of Kendra's Law in New York, ${ }^{386}$ and expressed that under the County's pilot program, petitions for PVOT were only filed for persons who agreed to accept services under the voluntary agreement for services section. ${ }^{387}$

One year and six months after the original Complaint was filed, the parties reached a settlement and the case was dismissed. ${ }^{388}$ The final settlement includes the following agreement between the parties, which will expire on January 1, 2008 (presumably, this date was chosen because at the time of the agreement, this was the date on which Laura's Law would have sunset, however, the sunset date was recently amended and extended until January 1, 2013) ${ }^{389}$ First, the parties agreed that the term "Laura's Law" would not be used by the Los Angeles County Mental Health Department in reference to its limited PVOT program based on Laura's Law. ${ }^{390}$ " 'Any law named after a single person can be an emotional reaction," "said the Executive Director of the nonprofit agency that brought the suit. ${ }^{391}$ Instead, the Los Angeles County

384 Id. at 3.

385 Points and Authorities In Support of Motion for Judgment on the Pleadings at 4, 9, Cal. Network of Mental Health Clients v. County of L.A. (No. BC 310719) (Sept. 22, 2004) (on file with author) [hereinafter Defendant's Motion for Judgment on the Pleadings]. Defendants made two primary procedural arguments in response to the Complaint: 1) that the plaintiff corporation lacked standing; and 2) that the Plaintiff failed to name indispensable parties. Id. Contra Memorandum of Points and Authorities In Opposition to Defendants' Motion for Judgment on the Pleadings, Cal. Network of Mental Health Clients v. County of L.A. (No. BC 310717) [sic] (Mar. 24, 2005) (on file with author).

386 See Defendant's Motion for Judgment on the Pleadings, supra note 385, at 6.

387 Id. at 3.

388 Request for Dismissal, Cal. Network of Mental Health Clients v. County of L.A. (No. BC 310719) (Sept. 29, 2005) (on file with author).

389 Final Settlement Agreement, supra note 378, at 7. See also Laura's Law, CAL. WELF. \& INST. CODE $§ 5349.5$ (West Supp. 2007) (extending the sunset date until 2013 but requiring that the State Department of Mental Health submit a report regarding the use of Laura's Law in California by July 31,2011 ).

390 See Final Settlement Agreement, supra note 378, at 2,

391 Dave Moller, Laura's Law May Be Extended, THEUNION.COM, Apr. 24, 2006, avail- 
Mental Health Department agreed and is therefore only permitted to refer to its limited application of "Laura's Law" as the "Voluntary Assisted Outpatient Treatment Program." 392 The term "voluntary," however, is clearly contrary to one of the key purposes of Laura's Law: to treat the severely mentally ill who lack insight into their illnesses and therefore are unlikely to seek voluntary treatment. ${ }^{393}$ Nonetheless, Los Angeles County maintained from the beginning that it had only adopted Laura's Law on a voluntary basis through the criminal diversion program. Second, the parties agreed that Los Angeles County would be permitted to continue to operate its limited pilot program of Voluntary Assisted Outpatient Treatment but under a few conditions: 1) if the program ever exceeds fifty patients, the County must notify Plaintiff's counsel; 2) if the County wishes to change or recommend any changes that would make the program involuntary in any nature, it must provide Plaintiff's counsel thirty days advanced notice prior to filing any letter of such recommendations to the Board of Supervisors; 3) the County will make clear that the only aspect of Laura's Law being used is the voluntary settlement process. ${ }^{394}$ Simply conceding that the program will likely never exceed fifty patients also suggests how limited the application of this pilot program is due to lack of resources to finance it. In exchange for this agreement from Los Angeles County, the Plaintiff agreed to

able at $\mathrm{http}: / / \mathrm{www}$. theunion.com/article/20060424/NEWS/104240143.

392 See Final Settlement Agreement, supra note 378, at 2.

393 CAL. Welf. \& INST. CODE $\S 5346$ (a)(5) (stating that the person has been offered an opportunity to voluntarily participate in PVOT but continues to fail to voluntarily participate).

394 Final Settlement Agreement, supra note 378, at 3 (the "voluntary settlement" section of Laura's Law is CAL. WELF. \& INST. CODE § 5347). See also E-mail Attachment from Alisa Dunn, Director, L.A. County Mental Health Department, Voluntary Assisted Outpatient Treatment Program (Mar. 27, 2007, 04:55:31 EDT) (on file with author) (specifying the limited operation of Los Angeles County's "Voluntary Assisted Outpatient Treatment Program). Candidates for PVOT in Los Angeles County currently include the following: 1) misdemeanor incompetent to stand trial defendants who have been restored to competency; 2) misdemeanor defendants who are at risk of becoming incompetent to stand trial; and 3) consumers who are transitioning from Community Reintegration Programs. Id. at 1 . The enrollment process virtually ignores the language of Laura's Law that permits family members and other designated parties to request that the Director file a petition on behalf of a third party and additionally focuses solely on defendants with a criminal history. See id.

Qualifying candidates are offered AOT and if they agree to treatment, the mental health designee files a petition for AOT. The petition is filed after candidates have been restored to competency and their criminal court case has been resolved.... The AOT court process . . . consists of consumers entering into a Settlement Agreement. ...

$\ldots$

Consumers who have completed an alternative sentencing program through DMH Community Reintegration may also be referred for AOT if they meet the criteria and express a desire to enroll in the Program. Candidates are referred to the mental health designee at Court 95 and enter into the Settlement Agreement as Described above.

Id. at 1-2. Additionally, the treatment provider has a client-staff ratio of ten to one with "service plans that address at least eleven elements prescribed in the statute." Id. at 2. 
file a dismissal without prejudice of the entire lawsuit against all Defendants and not bring any claims arising from the legal action. ${ }^{395}$

In summary, California's Laura's Law, though enacted in 2002, has as yet to be implemented by any California county. Los Angeles County, one of the largest counties in the state, lacked finances to fully implement the law but still chose to do so in a limited fashion. Even so its limited usage ultimately has currently stymied the use of the law within the county (except on a very limited voluntary basis) and possibly even the entire state. Other counties looking for reasons not to attempt implementing Laura's Law have only to look to the example of Los Angeles County. Los Angeles County was sued by non-profit mental health organizations for arguably failing to meet stringent statutory criteria. The lawsuit is extremely unfortunate because it has effectively deterred other counties from adopting Laura's Law within the state.

Nonetheless, counties that may wish to adopt Laura's Law should remember that the primary reason Los Angeles County settled the lawsuit was not because there was anything wrong with the substance of Laura's Law-for example, that it was weak in its constitutional structure - but rather because Los Angeles County simply executed it in a poor and arguably inadequate manner. ${ }^{396}$ If other California counties are interested in adopting Laura's Law, the primary hurdle in executing it properly is the provision mandating full financial responsibility onto local counties. In the mean time, counties interested in implementing the law should rigidly follow the standards and criteria Laura's Law sets forth. If counties are able to finance Laura's Law in full and meet all the guidelines, it is likely that Laura's Law will survive constitutional attacks as Kendra's Law has in the state of New York. ${ }^{397}$ Additionally, if a California county adopts Laura's Law, data within the state of California will begin to accumulate concerning PVOT, which will be important to determine whether the law as written has the power to help a population of severely mentally ill persons in the state of California.

\section{A. Proposition 63: The Mental Health Services Act}

Hope for financing Laura's Law in its voluntary aspects, may have recently come with the passage of Proposition 63 in 2004. ${ }^{398}$ Proposition 63 requires individuals with a personal annual income of over one million dollars to

395 Final Settlement Agreement, supra note 378, at 3.

396 Cf. CAL. WELF. \& INST. CODE $\S 5348$. See also supra notes $344-53$ and accompanying text.

397 See supra Part VII and notes 219-29 and accompanying text.

398 Mental Health Services Fund, CAL. REv.\& TAX. CODE $§ 17043$ (West Supp. 2007); cf. Watnik, supra note 222, at 1228 ("For Kendra's Law to be implemented successfully, the legislature must commit financially to making it work. Adequate funding is critical to ensure the availability of community treatment programs. A court order for [PVOT] is meaningless unless the resources are available to implement it."). 
pay a one percent tax, which goes directly toward expanding and improving the California mental health system. 399 "The tax surcharge [is estimated to] generate new state revenues of approximately $\$ 275$ million in $2004-05, \$ 750$ million in 2005-06, \$800 million in 2006-07, and probably increasing amounts annually thereafter." genuinely expand services for severely mentally ill persons, and as the law currently provides, on a voluntary basis. ${ }^{401}$ Nonetheless, investing in reforming and improving voluntary services will likely be indirectly related to effectively implementing many of the service-provider criteria set forth in Laura's Law. If finances are used to provide counties with higher quality services, including better staff-to-client ratios, it may be more realistic and somewhat less expensive for counties to adopt Laura's Law in the near future. ${ }^{402}$ With much mental health reform currently underway in the state of California, primarily through funding from the Mental Health Services Act, why not make efforts to implement a new involuntary law that has proven to reduce violence, homelessness, and criminalization of the mentally ill? ${ }^{403}$

Involuntary civil commitment statutes more generally are going to cost more money than voluntary civil commitment statutes as they likely come with more resistance and in turn, more litigation and appeals. Finances, however, are not the only obstacle to implementing Laura's Law in California. Supervi-

399 CAL. Welf. \& INST. CODE $§ 5891$.

400 Legislative Analyst's Office, http://www.lao.ca.gov/ballot/2004/63_11_2004.htm (last visited Mar. 8, 2006).

401 CAL. WELF. \& INST. CODE $\S 5891$ ("The funding established pursuant to this act shall be utilized to expand mental health services. These funds shall not be used to supplant existing state or county funds utilized to provide mental health services."); Id. $\$ 5801$ (b)(5) ("The client should be fully informed and volunteer for all treatment provided, unless danger to selfor others or grave disability requires temporary involuntary treatment.") (emphasis added). See also

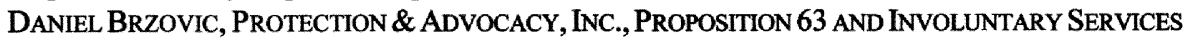
1, 3-6 (2004), available at http://www.pai-ca.org/advocacy/Prop63/Prop63andAB1421.pdf ("Proposition 63 provides that Proposition 63 funds can only be used to pay for specific, listed programs.") (describing why Proposition 63 funds may not be used to fund Laura's Law).

One might argue that Proposition 63 violates the Equal Protection clause by providing funds to improve mental health services for voluntary rather than involuntary patients. See supra Part VII and notes 242-46 and accompanying text. But again, since rational review is likely to be the standard of review applied, the policy choice to target a specific class of mentally ill persons - those who wish to seek services voluntarily under the Mental Health Services Actwould likely be upheld. See City of Cleburne v. Cleburne Living Ctr., 473 U.S. 432 (1985). Nonetheless, it is interesting at least to consider how the broader class of severely mentally ill persons is arguably unequally treated throughout the state of California under Proposition 63.

${ }^{402}$ See also E-mail from Rusty Selix, Co-Author, Proposition 63, Executive Director, Mental Health Association in California (Mar. 20, 2007 09:16:42 EDT) (on file with author) (stating that increasing the number of persons receiving voluntary treatment will also likely decrease the number of persons in need of involuntary treatment).

${ }^{403}$ Contra Cal. Network of Mental Health Clients, AB 2357-Why Oppose It, supra note 200 ("Before resorting to the extreme measure of denying the rights of a whole group of persons [under Laura's Law], give these voluntary community services a chance."). 
sor Helen Thompson, the former Assemblymember of California who originally introduced the bill, stated that the primary reason for the law's unpopularity is not a lack of state or local funds but rather the political opposition from civil rights groups. ${ }^{404}$ This Note shows that Laura's Law is still a very conservative movement away from the danger statutes, and although it is largely involuntary in nature, it has many procedural safeguards set-up within it to protect the civil liberties of the severely mentally ill.

\section{Alternatives to PVOT}

\section{A. Mental Health Courts as Criminal Diversion Programs}

Mental Health Courts are currently being implemented throughout the country to divert the severely mentally ill from the criminal justice system. ${ }^{405}$

404 Telephone Interview with Supervisor Helen Thompson, Board of Supervisors, Yolo County, Cal., in L.A., Cal. (Jan. 10, 2006).

405 Symposium, Mental Health Courts, 11 PsYchol. PuB. PoL'Y \& L. 507 (2005); Susan Stefan \& Bruce J. Winick, A Dialogue on Mental Health Courts, 11 PsYchol. PUB. POL'Y \& L. 507,507 (2005) ("The basic assumption underlying the mental health court model is that, for at least some defendants charged with minor nonviolent offenses and, in some cases, even for those charged with felonies, the problem is more a product of mental illness than of criminality and that facilitating the offender's access to mental health treatment is a more effective response to the underlying problem than criminal conviction and sentence."); Allison D. Redlich et al., The Second Generation of Mental Health Courts, 11 PsYCHOL. PUB. POL'Y \& L. 527, 527 (2005) (stating that between 1998 and 2003 the number of mental health courts in the United States increased from roughly ten to eighty); see also Lisa Shoaf, $A$ Case Study of the Akron Mental Health Court, 32 CAP. U.L. REv. 975, 975-77 (2004) (describing Akron, Ohio's mental health court). Often "mental health court" is the simply the term used to describe regular roundtable discussions (often on a weekly basis) between the prosecutor, public defenders, mental health experts, and the trial court judge concerning persons believed to be suffering from severe mental illnesses who have been charged with non-violent crimes. Mental Health Court Panel, 4th Annual Mental Health \& Criminal Justice Summit, Indianapolis (Mar. 23, 2007). Some courts, however, have begun to open up these diversion programs or "mental health courts" to severely mentally ill individuals charged with felonies or more violent crimes. Carol Fisler, Building Trust and Managing Risk: A Look At A Felony Mental Health Court, 11 PsYCHOL. PUB. POL'Y \& L. 587, 587-88 (2005) (describing the Brooklyn Mental Health Court of New York). See also Leslie Kaufman, Court for Mentally Ill Defendants Will Start Today, N.Y. TiMEs, Oct. 1, 2002, at B3 (describing the official opening of the Brooklyn Mental Health Court).

The first mental health court arguably took place in Marion County, Indiana under the direction of Judge Evan Goodman in 1996. Posting of Bob Cardwell, Introduction: The PAIR Mental Health Diversion Program of Marion County, to http://pairprogram.blogspot.com/2005/01/introduction.html, (Jan. 26, 2005, 10:08 EST) (stating additionally that the court has roots in the Psychiatric Assertive Identification Referral/Response ("PAIR") program of Marion County, Indiana, which was an informal diversion program for the severely mentally ill charged with crimes that began in the early 1980s). Cf. Stefan \& Winick, supra note 405 , at 507 (stating that the first mental health court in the United States to receive national attention was that of Broward County, Florida in1997). 
These courts are mostly judge-based and judge-driven, and therefore, when the individual judge leaves, the mental health court also leaves. ${ }^{406}$ The primary critique of mental health courts is that they often step in too late, after a criminal act has been committed before offering treatment. ${ }^{407}$ Nonetheless, their primary virtue is that they are diverting the mentally ill from incarceration, a setting that is likely to exacerbate psychiatric symptoms and lead to further deterioration. $^{408}$ One problem with relying on mental health courts, however, is that because they are judge-driven they are not uniform and fail to have the same power that state-wide legislation has to reform the mental health system on a broader basis. ${ }^{409}$ Nonetheless, on a case-by-case basis, the goals of mental health courts are consistent with many of the same purposes and goals of PVOT statutes.

\section{B. Rebuilding and Expanding Inpatient Hospitals}

Another alternative to PVOT, though initially it might sound a bit backwards, is to bolster the image and resources available to inpatient psychiatric hospitals by encouraging innovation and reducing the stigmatization associated with these facilities. A well-monitored and structured hospital may be the best hope for some severely mentally ill persons' long term improvement. ${ }^{410}$ This might even be particularly true during the first several years of the development

406 Robert Bernstein \& Tammy Seltzer, Criminalization of People with Mental Illnesses: The Role of Mental Health Courts in System Reform, 7 D.C. L. REv. 143, 147, 149 (2003); Barbara A. Collins, Mental Health Court Judge, Marion County, Ind., Remarks at Starting a Mental Health Court in Your Community, Panel Speaker at the 4th Annual Mental Health \& Criminal Justice Summit, Indianapolis (Mar. 23, 2007).

407 Tammy Seltzer, Mental Health Courts: A Misguided Attempt to Address the Criminal Justice System 's Unfair Treatment of People With Mental Illnesses, 11 PsYCHOL. PUB. PoL'Y \& L. 570, 572-73, 577, 581-83 (2005) ("To avoid becoming the entry point for people abandoned by the mental health system, mental health courts should close their doors to people charged with minor misdemeanors, as does the Brooklyn Mental Health Court, which handles only felonies and misdemeanors 'that would likely result in a jail sentence.' ... The criminal and juvenile justice systems are not the appropriate front door to access mental health care.... To eliminate the unnecessary and harmful criminalization of people with mental illnesses, communities must address the causes of the problem, not just its symptoms.") (quoting a New York State Office of Mental Health Report).

408 See Stefan \& Winick, supra note 405, at 507 (explaining, however, that scientific research still needs to be done to evaluate the effectiveness such courts).

409 See Collins, supra note 406. See also Nancy Wolff \& Wendy Pogorzelski, Measuring the Effectiveness of Mental Health Courts: Challenges and Recommendations, 11 PsYCHOL. PUB. POL'Y \& L. 539, 541-42 (2005) ("Mental health courts are fluid, nonstandardized entities.") (citation omitted). Cf. Corrections Mental Health Act of 2007, S.B. 851, 2007-08 Leg., Reg. Sess. (Cal. 2007) (enrolled Sept. 17, 2007) (authorizing the development of mental health courts throughout the state of California on a county-by-county basis).

410 See TORREY, SURVIVING SCHIZOPHRENIA, supra note 12, at 166-67 ("There are ancillary benefits of hospitalization for persons with schizophrenia."). 
of the illness. Simple innovations in modern architecture are being used by several state hospitals around the country to improve the environment of inpatient hospitals. ${ }^{411}$ These developments include providing natural light, gardens, and murals to make the hospitals feel more like boarding school rather than the cold and sterile institutions of the past. ${ }^{412}$ An additional advantage to inpatient hospitals is that they are fully staffed, and often provide patients with access to libraries, vocational programs, art classes, socials, gym class, outdoor space, gardens, dental and medical treatment, music therapy, or general psychosocial treatment. ${ }^{413}$ Additional funding to strengthen these programs could prove beneficial, particularly for those states that do not have PVOT or AOT. ${ }^{414} \mathrm{By}$ contrast, the Indiana State Government is leading a movement to privatize its state hospitals that may someday reduce the number of hospitals in the state, leaving many severely mentally ill by the wayside. ${ }^{415}$ If a movement to increase inpatient services is any kind of option worth considering, pressure needs to be placed on the federal government to repeal the Medicaid exclusion for coverage

411 E.g., Evansville State Hospital, Evansville, Ind. (opened in 2003). Ind. Fam. \& Soc. Servs. Admin., News Media Advisory: State Officials to Dedicate New Evansville State Hospital on Wednesday, Aug. 25, 2003 ("The new hospital will provide modern, up-to-date quarters for patients with severe mental illness who need residential treatment. The treatment facility will ... feel as little like an institution as possible. Nurses will monitor natural daylight in the building, and an elongated skylight over the therapeutic "treatment mall" will assure that the new space is bright, airy and non-institutional.") (on file with author).

412 Ind. Fam. \& Soc. Servs. Admin., New Evansville State Hospital: Fast Facts ("Some of the special architectural features in this facility include natural lighting, nature views, home-like settings, therapeutic color definition, visibility and security.") (architectural design by Veazey Parrott Durkin \& Shoulders) (on file with author). See also Gene Bunnell, The Importance of Comprehensive Planning for the Reuse of Mental Hospital Properties: Lessons Learned in Massachusetts and Connecticut, in CHANGING PLACES: REMAKING INSTITUTIONAL BUILDINGS 224-25, 242 (Lynda H. Schneekloth, Marcia F. Feuerstein \& Barbara A. Campagna eds., 1992) ("Far too many buildings at state mental hospitals have been allowed to deteriorate as a result of long term disuse and neglect. What has been lacking to-date, and what is desperately needed, is a positive vision of the contemporary possibilities .... to significantly improve and upgrade the facilities for the treatment of the mentally ill. ... Redevelopment and reuse needs to overcome the social and physical isolation which has helped to stigmatize state mental hospital properties. Planning can help accomplish this by increasing physical connections and social interaction between hospital properties and their surrounding communities.").

413 Interview with Brian K. Newell, Librarian, Logansport State Hospital, Logansport, Ind. (June 2006). E.g., TORREY, SURVIVING SCHIZOPHRENIA, supra note 12, at 167; contra SAKS, REFUSING CARE, supra note 18, at 54 ("Most hospital wards are locked, so there is drastically reduced freedom of movement. . . Opportunities for education and recreation may be limited.")

414 Treatment Advoc. Ctr., Assisted OutPatient Treatment, supra note 21, at 1 (citing Connecticut, Maine, Maryland, Massachusetts, New Jersey, New Mexico, Nevada, and Tennessee as the eight states that do not have any form of AOT whatsoever). Note that in several of these states AOT legislation is currently pending. See supra Part VI.B (discussing legislative AOT bills in New Mexico, Tennessee, and New Jersey).

415 See Mary Beth Schneider, Hospital Plans Questioned, INDIANAPOLIS STAR, Oct. 13, 2005 , at 5B. 
in such hospitals. ${ }^{416}$ Nonetheless, possibly we should have less fear when we think of "inpatient hospitalization" and maybe it is worth considering ways to expand these programs to genuinely improve the care of our severely mentally ill.

\section{Improving Awareness and Education of Severe Mental Illness Through Early Prevention}

"Australia offers an interesting counterpoint to Canadian and American thinking with respect to the care and treatment of chronically dangerous and mentally ill persons." 417 While prevention of severe mental illness is still the focus, Australia aims to diagnose mental illness at a much earlier stage, ideally in childhood or adolescence. ${ }^{418}$

[T]he mechanism used to decrease violent behavior in mentally ill individuals is not to commit them to outpatient treatment based on a history of dangerousness but, rather, to identify potentially dangerously mentally ill persons as early as possible . . . and [to] provide immediate, individualized psychiatric intervention in the community. ${ }^{419}$

Initiatives such as school screening, child health and court support services, specific programs for early psychosis intervention, and relapse management plans all play a role in detecting early warning signs of severe mental illness, and fostering timely outpatient intervention in the development of mental illness. $^{420}$ This community-based approach stresses the importance of early intervention for people who are developing, or who are at a high risk of developing, mental health problems or mental disorders in order to minimize the potentially debilitating effects of these conditions. ${ }^{421}$

Although early intervention is critical for successful treatment, one potential flaw of the system is considering that the onset of many severe mental illnesses is in adulthood. ${ }^{422}$ Nonetheless, a combination of addressing mental health at early stages in addition to PVOT statutes may be the ideal setting for an effective mental health care system of the future. ${ }^{423}$

416 Davoli, supra note 9, at 162.

417 Cornwell \& Deeney, supra note 3, at 231.

418 Id.

419 Id.

420 Id. at 232.

421 Id. at 231-32.

422 Cf. TORREY, SURVIVING SCHIZOPHRENIA, supra note 12, at 99-101 (describing childhood, postpartum, and late-onset schizophrenia).

${ }_{423}$ The early screening mechanism, however, may present some questionable constitu- 
An additional difference between the Australian policy and the American approach is that the concept of a court order appears to be absent from the community initiative program. ${ }^{424}$ This is because the goal is to prevent mentally ill individuals from reaching a heightened state of deterioration. While the Australian approach might be a greater intrusion on civil liberties, an indirect benefit is that the public becomes better educated about mental illness by making intervention initiatives a part of mainstream community health and education policies. ${ }^{425}$ It remains to be seen whether early identification of and treatment for individuals at risk of developing a severe mental illness will lead such individuals to use outpatient psychiatric services more efficiently. ${ }^{426}$

\section{Comprehensive Voluntary Services Programs}

California recently introduced the Mental Health Services Act that proposes a variety of methods for reforming the care of severely mentally ill persons through voluntary services. ${ }^{427}$ The first critical aspect of this statute is the generous provisions of financing, which has been secured with Proposition $63 .^{428}$ Without financial resources, a state has little prospects for reforming a mental health services delivery system. But with appropriate funding, expansions and improvements are currently being made in 1) education and training programs, 2) innovative programs; 3) prevention and early intervention programs; 4) oversight and accountability; and 5) children's services. ${ }^{429}$ The Mental Health Services Act, however, is focused primarily on improving voluntary rather than involuntary treatment programs. ${ }^{430}$ Some might argue that the focus on improving voluntary services is inconsistent with current scientific and medical data regarding the lack of insight among the severely mentally ill. ${ }^{431}$ Proponents, however, would counter that as voluntary services are expanded and improved, the need for involuntary services will greatly decrease.

tional issues in the United States; in particular, whether such screening is an unlawful search and seizure under the Fourth Amendment. But cf. Bd. of Educ. v. Earls, 536 U.S. 832, 837 (2002) (holding that a middle school and high school policy of drug testing in order to participate in extracurricular activities was a reasonable search).

${ }^{424}$ See Cornwell \& Deeney, supra note 3, at 231-32.

425 See id. at 232.

426 Id. "Whether such a restructuring of mental health services could ever be accomplished broadly in this country is open to serious question. In the meantime, we should support [PVOT] at home while keeping a watchful eye on developments Down Under." Id.

${ }_{427}$ This may include the implementation of mental health courts at the superior court level for mentally ill criminal offenders in the near future. See S.B. 851, 2007-08 Leg., Reg. Sess. (Cal. 2007).

${ }^{428}$ See supra notes 398-400 and accompanying text.

429 See CAL. WeLF. \& INST. CodE $\S \S 5820,5830,5840,5845,5851$ (West Supp. 2007); see also $\$ 5890$.

430 CAL. WeLf. \& INST. CODE $§ 5801(b)(5)$.

431 See supra notes 74-77 and accompanying text. 


\section{CONCLUSION}

There are many approaches to reforming the system of caring for the severely mentally ill. PVOT presents just one recent and promising option. While PVOT offers substantial improvement to a broken mental health system, there are at least two noticeable drawbacks, given the goal of shifting toward a more medically-based model of civil commitment.

First, PVOT statutes are less likely to help young adults beginning to develop a severe mental illness. This is because of their policy preference to exclude data from the most recent six months and the corresponding lack of a concrete history of severe mental illness for this age group. Sadly, science and medicine tell us that the earlier treatment is administered for severe mental illness, the more likely successful long-term recovery will occur. ${ }^{432}$ PVOT does not seem to be achieving this goal for this population.

Second, in order to be eligible for PVOT, PVOT statutes require at least two instances of psychiatric hospitalization or receipt of forced medication in an incarceration setting. ${ }^{433}$ There are several sub-populations of severely mentally ill individuals who easily may not meet this demanding criterion. Robert Gilmore-the individual who has been severely mentally ill and homeless for twenty years with forty arrests - may be one of them. ${ }^{434}$ Additionally, nonviolent severely mentally ill persons who may be less prone to arrest or civil commitment under the danger-or-grave-disability statutes may also be overlooked.

Despite these drawbacks, for states without any AOT of any kind, PVOT is a great stride toward updating and improving their mental health care systems. In particular, PVOT provides a more sustained and lengthy treatment period (at least six months) that helps many severely mentally ill persons better adhere to their treatment plans, which greatly improves their chances of longterm recovery. Furthermore, statistical studies such as in New York's Final Report on Kendra's Law provide concrete support that PVOT is an effective way to treat the chronically and severely mentally ill. This evidence should serve as a solid foundation for additional PVOT research, ideally through the adoption and implementation of PVOT in other states.

While it might be several decades before more PVOT studies are accumulated to reach a more definitive conclusion regarding the effectiveness of these statutes, there is no reason to doubt the successes that the New York Report identifies. New York City is hardly a trivial or mere experimental case. Homelessness, criminalization, victimization, and violence against and by the severely mentally ill have been dramatically reduced in New York apparently due

432 See supra note 106 and accompanying text.

433 See supra Part V.A.1.

434 See supra Part IV and notes 155-57 and accompanying text. 
to the adoption of Kendra's Law. ${ }^{435}$ As of now, the New York Report is substantial evidence that PVOT can be successful in states and counties that enact and implement it. Further, the New York Court of Appeals' decision, In re $K . L$., suggests that PVOT would likely be upheld by the United States Supreme Court or other state supreme courts as a constitutional exercise of state power. ${ }^{436}$

States without PVOT statutes in place should strongly consider adopting them. Kendra's Law, Laura's Law, and the PVOT laws of Florida and Michigan provide good models of prominent PVOT statutes, and include various optional policy positions to choose from, upon which states may draw. Sunset provisions, however, are probably a good idea until more concrete data have accumulated concerning the effectiveness of PVOT.

Like the movement of the 1950 s and 1960 s that motivated the danger statutes, the PVOT movement of the twenty-first century marks the evolution of a new type of statute that seeks to aid the severely mentally ill through a more medically-based model. As medical understanding of severe mental illness improves, psychiatric treatments continue to advance in sophistication, and our society begins to better appreciate the seriousness of severe mental illness, the laws that protect our severely mentally ill should reflect that change.

${ }^{435}$ See supra notes 300-01, 314 and accompanying text.

436 See supra notes 219-29 and accompanying text. 